\title{
Index for Volume 99 of Plant Disease
}

AUTHOR AND SUBJECT INDEX. Page numbers of errata are in italic. $\mathrm{N}$ indicates disease note.

Ćosić, J., 896N

Ćulafić, J., $1647 \mathrm{~N}$

Abate, D., 1488

Abbas, H. K., 1236

Abdalla, O. A., 734N

Abdeen, A. O., $1286 \mathrm{~N}$

Abdo, Z., 207

Abel, C. A., 1236

Abo, K., 1445N

Aboughanem-Sabanadzovic, N., 163N, 1347

Acantholimon hedinii, Erysiphe limonii on, in China, $1038 \mathrm{~N}$

Acer spp.

A. buergerianum (trident maple), Trichothecium roseum on, in China, $1864 \mathrm{~N}$

A. saccharum (sugar maple), Verticillium dahliae on, real-time PCR method for detection and monitoring of, 866

Aceria tosichella (wheat curl mite)

impact of wheat streak mosaic virus and triticum mosaic virus coinfection of wheat on transmission rates by, 1170

on wheat, effects of soil nitrogen and atmospheric carbon dioxide on, 1803

Acevedo, M., 1604

Acibenzolar-S-methyl, resistance of mango against Ceratocystis fimbriata and, 447

Acidovorax citrulli, on watermelon, in Serbia, $886 \mathrm{~N}$

Acremonium cucurbitacearum, on melon, in China, $1184 \mathrm{~N}$

Acrostalagmus luteo-albus, on needle mushroom, in China, $158 \mathrm{~N}$

Actinidia chinensis (kiwi)

Botryosphaeria spp. on, in China, 699

Corynespora cassiicola on, in China, 725N, Cover photo: May

Fusarium acuminatum on, in China, 1644N

Penicillium expansum on stored fruit, in China, 1037N

Phytopythium helicoides on, $725 \mathrm{~N}$

Pseudomonas syringae pv. actinidiae on, in Greece, $723 \mathrm{~N}$

Adams, I., $1870 \mathrm{~N}$

Adams, M., $1861 \mathrm{~N}$

Adandonon, A., 1854N

Adaskaveg, J. E., 1477

Ade, A. B., 1274N

Adebola, P., 1652N

Adkar-Purushothama, C. R., $1868 \mathrm{~N}$

Adkins, S., 895N, 1450N

Adzuki bean. See Vigna angularis

AEV. See Ageratum enation virus

Afanador-Kafuri, L., 994

Aflatoxin, Ustilago maydis on corn and, 1236

Afolabi, O., $735 \mathrm{~N}$

Afroz, T., $1865 \mathrm{~N}$

Ageratum enation virus (AEV), in Ageratum houstonianum, 621

Ageratum houstonianum, ageratum enation virus and ageratum leaf curl betasatellite in, 621

Ageratum leaf curl betasatellite (ALCB), in Ageratum houstonianum, 621

Agrobacterium vitis strain ARK-1, for crown gall control in diverse plant species, 409

Agrostis stolonifera (creeping bentgrass)

Hemicycliophora wyei on, in Texas, $732 \mathrm{~N}$

Sclerotinia homoeocarpa on, in Norway, $287 \mathrm{~N}$

Agudelo, P., 732N
Agustí-Brisach, C., 976

Ahohuendo, B. C., $1854 \mathrm{~N}$

Ai, C., $887 \mathrm{~N}$

Ai, J., $889 \mathrm{~N}, 1037 \mathrm{~N}, 1644 \mathrm{~N}$

Ailanthus altissima (tree-of-heaven), Verticillium nonalfalfae for control of, 823, 1070, Cover photo: Jun

Akgül, D. S., $1855 \mathrm{~N}$

Akhtar, N., $1448 \mathrm{~N}$

Akhunov, E., 1333

Akpa, A. D., 415N

Aktaruzzaman, M., $1865 \mathrm{~N}$

Alabi, O. J., $1290 \mathrm{~N}, 1656 \mathrm{~N}$

Albaz, E. A., $1855 \mathrm{~N}$

Albu, S., 1596

Albugo candida, on garden rocket, in South Africa, 290N

Alcántara, E., 488

Alcalá-Briseño, R. I., 557N

ALCB. See Ageratum leaf curl betasatellite

Alderman, S. C., 1410

Aledan, T. R., $1651 \mathrm{~N}$

Alegbejo, M. D., $415 \mathrm{~N}$

Aleksic, G., 1279N

Alexander, B. J. R., 1863N

Al-Fahdi, A. R., 419N

Alfalfa. See Medicago sativa

Alfalfa mosaic virus (AMV)

in Carthamus tinctorius, in Serbia, 896N

in potato, in Canada, $1658 \mathrm{~N}$

Alfaro-Fernández, A., $1175 \mathrm{~N}$

Alfenas, A. C., 106

Algae, as plant pathogens, 740, Cover photo: Jun

Ali, A., $736 \mathrm{~N}$

Ali, I., 736N

Alice, D., $1190 \mathrm{~N}$

Alioto, D., $1655 \mathrm{~N}$

Aljawasim, B., 866

Al-Khafaji, R., $1188 \mathrm{~N}$

Alkooranee, J. T., 1651N

Allen, T., $418 \mathrm{~N}$

Allen, T. W., 1347

Allium spp.

A. cepa (onion)

Alternaria alternata on, in South Africa, $1652 \mathrm{~N}$

Fusarium sp. FIESC 3 on, in Serbia, 1277N

Klebsiella pneumonia on, in China, 1853N

Pantoea agglomerans on, in Michigan, 1034N, Cover photo: Jul

Rhizoctonia spp. on, in Oregon and Washington, 648

A. cepa var. aggregatum (shallot), onion yellow dwarf virus in, in Serbia, $1450 \mathrm{~N}$

A. porrum (leek), Fusarium avenaceum on, in California, 1864N

A. sativum (garlic)

Aspergillus parvisclerotigenus on, in Pakistan, $1448 \mathrm{~N}$

Erwinia persicina on, in Europe, $723 \mathrm{~N}$ garlic common latent virus in, in Serbia, $894 \mathrm{~N}$ Garlic virus A in, in India, 1288N

Alloatti, J., 1140

Al-Mahmooli, I. H., 419N

Almeida, R. P. P., 1457

Almond. See Prunus dulcis

Aloe barbadensis (Barbados aloe), Fusarium oxysporum on, in Greece, $1649 \mathrm{~N}$

Al-Sadi, A. M., 419N, 421N

Al-Saleh, M. A., 734N, 894N

Alsalimiya, M., 58

Al-Shahwan, I. M., 734N, 894N

Al-Shihi, A., 421N
Alster, S., 621

Alternaria spp

A. alternata

on Bruguiera gymnorrhiza, in China, 286N

on Chinese banyan, in China, $1652 \mathrm{~N}$

on citrus, in Taiwan, $1864 \mathrm{~N}$

on Idesia polycarpa, in China, $1177 \mathrm{~N}$

on jujube, in China, 1643N

on onion, in South Africa, 1652N

on peach: fitness and competitive ability

of isolates with fungicide resistance,

1744; SDHI fungicide resistance

and, 65

on persimmon, in Spain, 1416

on pomegranate: disease etiology of, 496; in Italy, $1446 \mathrm{~N}$

on radicchio, in Greece, 1867N

on rubber trees, in China, $290 \mathrm{~N}$

on spinach, in Poland, $729 \mathrm{~N}$

on tangerine, sensitivity to boscalid and polymorphism in iron-sulfur and in anchored membrane subunits of

succinate dehydrogenase, 231

on teak, in China, $887 \mathrm{~N}$

A. brassicae, on horseradish, in Serbia, $730 \mathrm{~N}$

A. infectoria, on spelt wheat, in Serbia, 1647N

on sugarcane, in China, $1176 \mathrm{~N}$

A. tenuissima, on spelt wheat, in Serbia, $1647 \mathrm{~N}$

Alvarado-Gómez, O. G., 553N

Álvarez, B., 1449N

Álvarez, E., 994

Alves, E., $1177 \mathrm{~N}$

Amaro, M., 488

Ambrosia artemisiifolia, Cuscuta australis on, in China, $1285 \mathrm{~N}$

Amby, D. B., 1278N

Amer, M. A., 734N, 894N

American nightshade. See Solanum americanum

American sycamore. See Platanus occidentalis

Amin, I., $421 \mathrm{~N}, 1655 \mathrm{~N}$

Amin, U., 1448N

Amirsadeghi, S., 1002

Ammara, U. E., 421N

Amur grape. See Vitis amurensis

AMV. See Alfalfa mosaic virus

Ananas comosus (pineapple)

Fusarium spp. on

F. ananatum, in China, $1653 \mathrm{~N}$

$F$. oxysporum and $F$. solani, in Malaysia, $1650 \mathrm{~N}$

Anco, D. J., 926

Anderson, S. J., 1847

Andrade, C. C. L., $1177 \mathrm{~N}$

Andrade-Michel, G., 552N

Andrographis paniculata (Kalmeagh)

Catharanthus yellow mosaic virus in, in northern India, 292N

phytoplasma 16SrIID on, in India, $155 \mathrm{~N}$

Anethum graveolens (dill), Itersonilia perplexans on, in Cyprus, $1648 \mathrm{~N}$

Anguina spp., real-time PCR methods for detection and identification of, 1584

Ann, P. J., 1649N

Annona cherimola (cherimoya), Dactylonectria macrodidyma on, in Chile, $1282 \mathrm{~N}$

Anthurium crystallinum (crystal anthurium),

Xanthomonas axonopodis pv. dieffenbachiae on, in China, $1268 \mathrm{~N}$

Aphanomyces euteiches

on alfalfa, mineral seed coating for control of, 614

on field pea, in Alberta, Canada, 288N 
Apium graveolens (celery)

Colletotrichum acutatum on, characterization, virulence, epidemiology, and management of, 1832

Orobanche ramosa on, in Italy, 1188N, Cover photo: Aug

Physarum cinereum on, in Italy, $1272 \mathrm{~N}$

Spiroplasma citri on, in Spain, $1175 \mathrm{~N}$

tomato spotted wilt virus in, in China, 734N

Apple. See Malus spp.

Apple chlorotic leaf spot virus (ACLSV), in

Hawthorn, in China, 164N

Apricot. See Prunus armeniaca

Araújo, W. L., $1642 \mathrm{~N}$

Arachis hypogaea (peanut)

Aspergillus niger on, in China, 284N

bean common mosaic virus-peanut strain in, in Argentina, $735 \mathrm{~N}$

cucumber mosaic virus in, in South Korea, $733 \mathrm{~N}$

Rhamphicarpa fistulosa on, in Togo, 1654N

Rhizopus arrhizus on, in China, 1448N

Araj, S., 1286N

Araneda, M. J., 891N

Araujo, L., 447

Aravintharaj, R., 559N

Arceuthobium abietinum

on Engelmann spruce, in Oregon, 1041N, Cover photo: Jul

Areca catechu (areca palm), phytoplasma associated with, in Sri Lanka, 1642N

Armengol, J., 976

Armoracia rusticana (horseradish)

Alternaria brassicae on, $730 \mathrm{~N}$

Cercospora armoraciae on, in Serbia, $1645 \mathrm{~N}$

Arnao, E., 544

Arquero, O., 488

Arrowhead. See Sagittaria sagittifolia

Arruabarrena, A., 895N

Artemisia selengensis (Seleng wormwood),

Pectobacterium carotovorum subsp.

carotovorum on, in China, $1175 \mathrm{~N}$

Arthrocladiella mougeotii, on goji berry, in

China, $1283 \mathrm{~N}$

Artichoke, Verticillium klebahnii and V. isaacii on, host range of, 933

Artocarpus heterophyllus (jackfruit),

Meloidogyne enterolobii on, 1284N, 1868N

Arugula. See Eruca vesicaria subsp. sativa

Ascochyta spp.

on pea, lentil, and chickpea, sensitivity to boscalid, fluxapyroxad, and prothioconazole, 1254

on spotted locoweed, in Idaho, $1446 \mathrm{~N}$

Ash. See Fraxinus spp.

Ashfaq, M., 1870N

Ashrafi, H., 718

Asian ginseng. See Panax ginseng

Aspalathus linearis (rooibos), Rhizoctonia spp. associated with, compost as soil amendment for disease suppression and, 1020

Asparagus officinalis, Phytophthora sp. on, in Japan, $1857 \mathrm{~N}$

Aspergillus spp.

A. flavus, community structure of in major almond-producing areas of California, 1161

A. niger, on peanut, in China, $284 \mathrm{~N}$

A. parasiticus, community structure of in major almond-producing areas of California, 1161

A. parvisclerotigenus, on garlic, in Pakistan, $1448 \mathrm{~N}$

Assogba-Komlan, F., 1640N

Astragalus lentiginosus (spotted locoweed),

Ascochyta sp. on, in Idaho, $1446 \mathrm{~N}$

Ateka, E. M., 899N

Aucuba japonica, Phytophthora pachypleura on, in Italy, $1860 \mathrm{~N}$

Audoly, G., 1446N

Auger, J., 891N, 1282N

Avci, F., $1181 \mathrm{~N}$

Aveling, T. A. S., 290N

Avellaneda, M. C., 1633
Avilán, D., 896N, 1657N

Avocado. See Persea americana

Awan, Z. A., 1448N

Ayala-Escobar, V., 1041N

Ayalew, A., 1488

Ayalneh, D., 1870N

Azalea. See Rhododendron spp.

Azoxystrobin

for Colletotrichum siamense on peach and blueberry, 806

for Rhizoctonia solani on rice, 883

Büttner, C., 1578

Babu, B., 1488

Babu, T. K., 1784

Bacillus amyloliquefaciens, on arrowhead, in China, $1270 \mathrm{~N}$

Badillo-Vargas, I. E., 1450N

Baek, D.-S., 733N

Baek, I. Y., 1189N

Baenziger, P. S., 1333

Bagewadi, B., 293N, 1286N

Bagi, F., 1647N

Bagiotto, C., 1040N

Bai, C., $1868 \mathrm{~N}$

Bai, H., $1856 \mathrm{~N}$

Bai, J. Y., 1643N

Bai, L.-C., 289N

Bai, Q., 1182N, 1652N, 1653N, 1704

Balaji, C. G., 558N

Balatti, P. A., 1869N

Balaž, J., 281N

Balloon flower. See Platycodon grandiflorus

Bamboo, heavenly. See Nandina domestica

Bamboo mosaic virus (BaMV), in bamboo, in mainland China, $1189 \mathrm{~N}$

Bampi, D., 292N

Banana. See Musa spp.

Bani Hashemian, S. M., 125

Banihashemi, Z., 1181N

Bansal, U. K., 508

Banyan, Chinese. See Ficus microcarpa

Bao, Y., $1176 \mathrm{~N}$

Bao, Z. Z., 1270N

Barberry. See Berberis spp.

Barbetti, M. J., 112, 580, 770, 1544

Barclay, S., 614

Barda, O., 621

Bariana, H. S., 508

Barranco, D., 58

Basil, sweet. See Ocimum basilicum

Basnet, B. R., 1153

Batzer, J. C., 564

Baucom, D., 891N

Bayberry, red/Chinese. See Myrica rubra

Baysal-Gurel, F., 163N, 285N, 553N, 1445N, 1854N

Bažok, R., 1656N

BCMV. See Bean common mosaic virus

BCMV-PST. See Bean common mosaic virus-peanut strain

Beale, J., 421N

Bean, broad. See Vicia faba

Bean, common. See Phaseolus vulgaris

Bean, red adzuki. See Vigna angularis

Bean, yardlong. See Vigna unguiculata

Bean common mosaic virus (BCMV) in Cudrania tricuspidata, in Korea, 292N in soybean, in Korea, $1189 \mathrm{~N}$

Bean common mosaic virus-peanut strain (BCMV-PST), in peanut, in Argentina, $735 \mathrm{~N}$

Bean pod mottle virus (BPMV), in soybean, effect of time of infection on yield and quality, 1026

Bean yellow mosaic virus (BYMV), in canna in India, 897N multiplex RT-PCR assay for detecting, 1695 reliable detection for, 188

Beanland, L., 1087

Beattie, G. A., 564

Beaulieu, C., 1010
Bec, S., 1622

Bedendo, I. P., 423N

Beech. See Fagus sylvatica

Beed, F., 415N, 886N

Beed, F. D., 420N

Beet necrotic yellow vein virus (BNYVV) in red table beet, in Brazil, 423N sugar beet storage and, 1296

Beet yellows virus $(B Y V)$, in sugar beet, in Croatia, $1656 \mathrm{~N}$

Begonia spp.

B. elatior, Phytophthora niederhauserii on, in France, $1277 \mathrm{~N}$

B. $\times$ Hiemalis (hiemalis begonias), Myrothecium roridum on, in China, $1866 \mathrm{~N}$

B. semperflorens, Rhizoctonia solani AG1-IB on, in China, $1652 \mathrm{~N}$

Bejerman, N., $735 \mathrm{~N}$

Belasque Jr., J., 207

Belisario, A., $155 \mathrm{~N}$

Bellanger, M. N., 370

Bellflower, bonnet. See Codonopsis lanceolata

Bellflower, creeping/rampion. See Campanula rapunculoides

Ben, H.-Y., 1447N, 1866N

Bentgrass, creeping. See Agrostis stolonifera

Benzothiostrobin, for Sclerotinia sclerotiorum on rape, 969

Berberis spp. (barberry), Puccinia spp. on

$P$. graminis f. sp. tritici in U.S. Pacific northwest, 1507 wheat stem rust and, 1113

P. striiformis $\mathrm{f}$. sp. tritici, inability to be alternate host in U. S. Pacific northwest, 1500, 1507, Cover photo: Nov

Bergera koenigii (curry), Diaphorina citri on, postharvest quarantine treatments for, 916

Bergstrom, G. C., 1039N, 1284N, 1360

Bermudagrass. See Cynodon dactylon

Berniak, H., 281N

Bertaccini, A., 1578

Bertetti, D., 161N, 162N, 729N, 1037N, 1039N, $1448 \mathrm{~N}, 1868 \mathrm{~N}$

Berti, S., $155 \mathrm{~N}$

Bertsch, C., 1859N

Berube, J. A., $558 \mathrm{~N}$

Besada, C., 1416

Besler, K. R., $1175 \mathrm{~N}$

Bessin, R., 564

Beta vulgaris

B. v. subsp. cicla (chard)

Pseudomonas syringae pv. syringae on, in Serbia, $723 \mathrm{~N}$

Ralstonia solanacearum on, in Taiwan, 282N

B. v. subsp. saccharifera (sugar beet),

Pseudomonas syringae pv. aptata on, in Serbia, $281 \mathrm{~N}$

B. v. subsp. vulgaris cv. Boro (red table beet), Beet necrotic yellow vein virus in, in Brazil, $423 \mathrm{~N}$

B. v. (sugar beet) beet yellows virus in, in Croatia, $1656 \mathrm{~N}$ Cercospora beticola on, PCR-RFLP analysis to monitor fungicide resistance, 355 influence of harvest timing, fungicides, and beet necrotic yellow vein virus on storage of, 1296 Rhizoctonia solani AG4-HG-I on, in China, $1185 \mathrm{~N}$

Betel vine. See Piper betel

Beuve, M., 293N, 422N

Bhatt, B. S., $1291 \mathrm{~N}$

Bhuiyan, S. A., 93, 1367

Bian, C. H., 890N

Bian, Y. B., 287N

Biggs, A. R., 1526

Bigirimana, J., 899N

Bihon, W., 1652N

Binucleate Rhizoctonia sp. (BNR)

on azalea, spread from nursery propagation floors to trays containing stem cuttings, 842 
on potato

anastomosis groups and pathogenicity, 1790 new anastamosis group of, 1757

Bioassays, for estimating fungicide residue on peach, 1727

Biofumigation, Phytophthora capsici on

Brassica spp. and, 1721

Biological control agents

Agrobacterium vitis strain ARK-1, for crown gall control in diverse plant species, 409

Cladosporium cladosporioides $\mathrm{H39}$, for control of Venturia inaequalis on apple, 535

Pseudozyma aphidis, resistance against Clavibacter michiganensis on tomato and, 621

Verticillium nonalfalfae, for control of tree-ofheaven, 823, 1070, Cover photo: Jun

Birdsell, T., 724N

Birgaentzle, C., $421 \mathrm{~N}$

Bispo, W. M. S., 447

Bittara, F. G., 788

Bitter gourd. See Momordica charantia

Black-eyed Susan. See Rudbeckia fulgida

Blagojević, J., 730N

Blake, J., $1038 \mathrm{~N}$

Blanchette, R. A., 1038N

Blanco-Vargas, M., 1855N

Blanket flower. See Gaillardia x grandiflora

Blin, V., 421N

$\mathrm{BlMaV}$. See Blueberry mosaic associated virus

Blomquist, C. L., 1856N

Blueberry. See Vaccinium spp.

Blueberry mosaic associated virus (B1MaV), in

blueberry, in Kentucky, $421 \mathrm{~N}$

Bluhm, B. H., 544

Blume, E., $1040 \mathrm{~N}$

Blumeria graminis f. sp. tritici, on wheat development of weather- and airborne inoculum-based models to describe disease severity, 395

new alleles of $P m 2$ for resistance to, 1118

BNR. See Binucleate Rhizoctonia sp.

Bočarov-Stančić, A., 1647N

Bock, C. H., 207, 916, 1104, 1125

Bodroža-Solarov, M., 1647N

Boiteux, L. S., 895N

Bond, J. P., 544

Bonnet bellflower. See Codonopsis lanceolata

Boscalid

Alternaria alternata on tangerine and, 231

for Ascochyta spp. on pea, lentil, and chickpea, 1254

for Botrytis cinerea on grape, isolation of resistant isolates carrying the mutations H272R, H272Y, P225L, and P225H, 891N

for Didymella bryoniae on watermelon and muskmelon, resistance against multiple fungicides and, 815

Botryosphaeriaceous fungi

B. dothidea, on tobacco, in China, $890 \mathrm{~N}$

on grape, characterization of as causal agents of trunk diseases, 1678

on kiwifruit, in China, 699

B. obtusa, on apricot, in China, $888 \mathrm{~N}$

Botrytis spp.

on broad bean, PCR-based assays for detecting and differentiating three species, 691

B. cinerea

on cineraria, in Korea, $1865 \mathrm{~N}$

on grape, isolation of boscalid resistant isolates carrying the mutations $\mathrm{H} 272 \mathrm{R}$, H272Y, P225L, and P225H, 891N on Japanese plum, in Chile, $888 \mathrm{~N}$ on Saposhnikovia divaricata, in China, 1277N on siler, in China, 1644N

on strawberry: population from single field in Germany with complex fungicide resistance pattern, 1076; population structure, fungicide resistance profile, and $s d h b$ mutation frequency, 240 on tomato: population structure, fungicide resistance profile, and $s d h b$ mutation frequency, 240; relationship of conidium concentration to flower and stem infections, 137

B. pseudocinerea, on tomato, in China, $283 \mathrm{~N}$

Bottomley, E., $1870 \mathrm{~N}$

Boucher, T. J., 564

Bowness, R., 288N

Boxwood. See Buxus spp.

Boyer, C., 1854N

Boykin, D., 1517

BP15, for control of Stemphylium vesicarium on pear, 1816

BPMV. See Bean pod mottle virus

Bradley, C. A., 347, 544, 1434

Braidwood, L., 1870N

Braman, S., 14

Brannen, P. M., 65

Brar, G., 1863N

Brasier, C., 1133

Brassica spp.

B. juncea, Plasmodiophora brassicae on, resistance in genotypes from China, 776

B. napus

Erysiphe cruciferarum on, in China, 1651N

Plasmodiophora brassicae on, risk potential of, 667

turnip yellows virus in, in Serbia, 1869N

as cover crop for control of Rhizoctonia solani on rice, 883

Leptosphaeria maculans and L. biglobosa on, effect of water flooding on survival in stubble, 1426

B. oleracea, Xanthomonas campestris pv. raphani $(X c r)$ on, in Portugal, $283 \mathrm{~N}$

B. oleracea var. capitata, Sclerotinia sclerotiorum on, in New Mexico, $891 \mathrm{~N}$

B. rapa, Plasmodiophora brassicae on, resistance in genotypes from China, 776

Sclerotinia sclerotiorum on, effects of the novel fungicide benzothiostrobin on, 969

Brassica yellows virus ( $\mathrm{Br} Y \mathrm{~V})$, in tobacco, in

China, 1192N

Bratsch, S., 422N

Brawner, J. T., 71

Braz, G. B. P., 1037N

Bremia lactucae, on lettuce, impacts of weather on infection efficiency, 1010

Brito, J. A., 1284N

Brito, M., 1657N

Brlek, T., 1647N

Broad bean. See Vicia faba

Broggini, G. A. L., 370

Brome mosaic virus (BMV), in triticale, coinfection with wheat streak mosaic virus, $1290 \mathrm{~N}$

Brooks, F., 740

Brown, A., 1857N

Brown, J. K., 732N, 1287N

Browne, G. T., $1863 \mathrm{~N}$

Bruckart III, W. L., 1275N

Brueggeman, R. S., 1860N

Bruguiera gymnorrhiza, Alternaria alternata on, in China, $286 \mathrm{~N}$

Bruns, H. A., 1236

Brurberg, M. B., 287N

Bruton, B. D., 564

Bryce, S., 1870N

BrYV. See Brassica yellows virus

Buck, H., 1269N

Buckwheat. See Fagopyrum esculentum

Budakov, D., 281N

Buffalo gourd. See Cucurbita foetidissima

Bulajić, A., 286N, 709, 894N, 896N, 1869N

Bull, C. T., 415N

Buranapanichpan, S., 225

Bureka lemon. See Citrus limon

Burkholderia spp.

B. glumae, on rice, in northern India, $1268 \mathrm{~N}$
B. gladioli, on Oncidium orchids, in Brazil, 1642N Burks, T., $1268 \mathrm{~N}$

Burnett, A. L., 467

Burnett, F. J., 1197

Burrows, M., 1254, 1383

Bursaphelenchus spp.

B. xylophilus, on Pinus radiata, in Spain, $1449 \mathrm{~N}$

B. yongensis

on Pinus rigida, in Korea, 162N, Cover photo: Jan

Bus, V. G. M., 370

Bushe, B. C., $1276 \mathrm{~N}$

Bussereau, F., 551N

Butler, S., 724N

Buttercup, Persian. See Ranunculus asiaticus

Butterfly lavender. See Lavandula stoechas

Butternut. See Juglans cinerea

Buxdorf, K., 621

Buxus spp. (boxwood)

Calonectria pseudonaviculata on management with fungicides and less susceptible host species and varieties, 363

soil inoculum production, survival, and infectivity of, 1689

Colletotrichum theobromicola on, in United States, $1274 \mathrm{~N}$

Phytophthora occultans on, in Oregon, 1282N

Byamukama, E., 1026, 1176N

BYMV. See Bean yellow mosaic virus

Byun, H.-S., 588

BYV. See Beet yellows virus

Cañizares, M. C., 780, 1270N

Cabbage. See Brassica oleracea var. capitata

CABYV. See Cucurbit aphid-borne yellows virus

Cacciola, S. O., 1446N

Cadophora gregata, zucchini shoestring virus in, in New York, $1284 \mathrm{~N}$

Caffier, V., 370

Cai, G., 1596

Cai, X., 1426

Cai, Y. F., $1179 \mathrm{~N}$

Cai, Z. Y., 290N

Calendula officinalis (marigold)

cucumber mosaic virus in, in Serbia, 736N

Puccinia lagenophorae on, in Czech Republic, $892 \mathrm{~N}$

Calla lily. See Zantedeschia ellitiona

Calonectria pseudonaviculata, on boxwood management with fungicides and less susceptible host species and varieties, 363

soil inoculum production, survival, and infectivity of, 1689

Calvo-Salazar, V., 508, 1153

Camalexin, Sclerotinia sclerotiorum on Camelina sativa and, 1544

Camargo, L. E. A., 157N

Camelina sativa, Sclerotinia sclerotiorum on, camalexin production and, 1544

Camellia sinensis (tea), Nigrospora sphaerica on, in China, $417 \mathrm{~N}$

Camelo, V. M., 423N

Campanula rapunculoides, Rhizoctonia solani AG 1-IB on, in Italy, $1037 \mathrm{~N}$

Campos-Martínez, A., 555N

Candidatus spp.

'Ca. Phytoplasma asteris' on jointleaf rush, in Poland, $281 \mathrm{~N}$ on kumquat, in Mexico, $552 \mathrm{~N}$

' $C a$. Phytoplasma cynodontis, on bermudagrass, differentiation based on $16 \mathrm{~S}$ rRNA and groEL genes and identification of a new subgroup, 16SrXIV-C., 1578

'Ca. Phytoplasma pruni' on grape, novel NAGY phytoplasma sequevars related to, 1087, Cover photo: Aug on lilac, $886 \mathrm{~N}$ 
'Ca. Phytoplasma solani, on bean, in Serbia, $551 \mathrm{~N}$

'Ca. Liberibacter asiaticus'

on citrus: in Costa Rica, 1855N; seasonal variations in populations of, 1125; ultrastructural changes and putative phage particles observed in leaves infected with, 320

'Ca. Liberibacter solanacearum'

on carrot, in Germany, $1269 \mathrm{~N}$

on seed potato, emergence in relation to time of infection, 274

silver nightshade as reservoir host for, 910

Candresse, T., 293N, 421N, 422N

Canna spp.

C. $\times$ generalis, multiplex RT-PCR assay for detecting potyviruses and a pararetrovirus in, 1695

bean yellow mosaic virus, canna yellow streak virus, and canna yellow mottle virus in, reliable detection for, reliable detection for, 188

bean yellow mosaic virus in, in India, $897 \mathrm{~N}$

Canna yellow mottle virus (CaYMV)

in betel vine, in India, 1189N

in canna plants

multiplex RT-PCR assay for detecting, 1695 reliable detection for, 188

Canna yellow streak virus (CaYSV), in canna plants multiplex RT-PCR assay for detecting, 1695 reliable detection for, 188

Cao, J. F., 890N

Cao, K. Q., 553N

Cao, S., $1861 \mathrm{~N}$

Cao, X., 395

Cao, Y.-Y., $1184 \mathrm{~N}$

Cao, Z.-M., 289N

Capsicum spp.

C. frutescens (red pepper), pepper vein yellows virus in, in mainland China, $1190 \mathrm{~N}$

C. annuum (pepper)

dahlia mosaic virus in, $898 \mathrm{~N}$

Meloidogyne enterolobii on, in China, 557N

pepper mild mottle virus in, in Oklahoma, $736 \mathrm{~N}$

pepper vein yellows virus in: in China, $1288 \mathrm{~N}$; in United States, $1656 \mathrm{~N}$ tomato spotted wilt virus in: resistance and, $1869 \mathrm{~N}$; in Venezuela, $896 \mathrm{~N}$

Verticillium dahliae on, screening of wild and cultivated germplasm for new sources of resistance, 1404

Xanthomonas euvesicatoria on, in Korea, $1640 \mathrm{~N}$

Carbendazim

PIRA-PCR for detection of genotypes with resistance alleles in Fusarium fujikuroi on rice, 1241

resistance of Fusarium asiaticum against, in China, 342

Sclerotinia sclerotiorum pathogenicity stimulation by subtoxic doses of, 1342

Carica papaya (papaya)

Corynespora cassiicola on, in Taiwan, $1649 \mathrm{~N}$ tomato leaf curl Albatinah virus in, in Oman, $421 \mathrm{~N}$

Carisse, O., 137, 1010

Carlucci, A., 1678

Carmignani, S., 1860N

CarMV. See Carnation mottle virus

Carnation. See Dianthus caryophylinus

Carnation etched ring virus (CERV), in carnation, in Mexico, $1191 \mathrm{~N}$

Carnation Italian ringspot virus (CIRV), in chrysanthemum, in Korea, $1451 \mathrm{~N}$

Carnation mottle virus (CarMV), in carnation, in

Mexico, $1191 \mathrm{~N}$

Carnegie, A. J., 161N, 1182N

Carneiro, J. E. S., 1098, 1537

Carrieri, R., $1272 \mathrm{~N}$

Carrizo citrange. See P. trifoliata $\times C$. sinensis
Carrot. See Daucus carota

Carthamus tinctorius, alfalfa mosaic virus in, in Serbia, 896N

Carvajal-Yepes, M., 733N

Carya spp.

C. cathayensis (Chinese hickory), Fusarium oxysporum on, in China, 1284N

C. illinoinensis (pecan)

Fusicladium effusum on, effect of sample height on fungicide spray coverage, 916 Pestalotiopsis microspora on, in China, 1276N

Caryota mitis (clustering fishtail palm)

Lasiodiplodia jatrophicola on, in China, 1038 N, Cover photo: Jul

Cassava

cassava common mosaic virus and cassava frogskin-associated virus in, in Argentina, 733N

East African cassava mosaic Malawi virus in, in Zambia, $1290 \mathrm{~N}$

Xanthomonas axonopodis pv. manihotis on

in Burkina Faso, 551N

in Ivory Coast, $1445 \mathrm{~N}$

Cassava common mosaic virus (CsCMV)

in cassava, in Argentina, 733N

in chaya, in Venezuela, $1190 \mathrm{~N}$

Cassava frogskin-associated virus (CsFSaV), in cassava, in Argentina, $733 \mathrm{~N}$

Casset, C., $1277 \mathrm{~N}$

Cassia fistula (golden shower tree),

Lasiodiplodia theobromae on, in China, $288 \mathrm{~N}$

Castlebury, L. A., 195

Casuarina equisetifolia, Fusarium lacertarum on, in Brazil, 1040N

Catharanthus roseus, tomato chlorotic spot virus in, in United States, 895N

Catharanthus yellow mosaic virus (CYMV)

in Kalmegh, in northern India, 292N

in mandevilla, in United States, $165 \mathrm{~N}$

Cating, R. A., 1279N

Cawthray, G. R., 1544

CaYMV. See Canna yellow mottle virus

CaYSV. See Canna yellow streak virus

CCDaV. See Citrus chlorotic dwarf associated virus

CChMVd. See Chrysanthemum chlorotic mottle viroid

CCYV. See Cucurbit chlorotic yellows virus

CDV. See Colombian datura virus

Ceanothus spp., Phytophthora occultans on, in Oregon, $1282 \mathrm{~N}$

Cedrus atlantica (Atlantic cedar), Sirococcus tsugae on, in Britain, $1857 \mathrm{~N}$

Celery. See Apium graveolens

Cell-free toxic culture filtrates, Fusarium virguliforme on soybean and, 502

Celosia cristata, Iresine viroid 1 in, in Italy, $1655 \mathrm{~N}$

Celtis australis (European hackberry),

Phytophthora megasperma on, in Italy, 155N

Cerasus avium (cherry), Phytophthora

nicotianae on, in China, $284 \mathrm{~N}$

Ceratocystis fimbriata

on mango, induction of the phenylpropanoid pathway by acibenzolar-S-methyl and potassium phosphite increases resistance to, 447

on Ohi?a, in Hawai' $i, 1276 \mathrm{~N}$

on pomegranate and taro, in China, relationship to populations on Eucalyptus in Brazil, 106

Cercis canadensis (redbud), Verticillium dahliae on, real-time PCR method for detection and monitoring of, 866

Cercospora spp.

C. armoraciae, on horseradish, in Serbia, $1645 \mathrm{~N}$

C. beticola, on sugar beet, PCR-RFLP

analysis to monitor fungicide resistance, 355

C. kikuchii, on soybean

fungicide resistance in, 1596 screening germplasm collection for reaction to stain caused by, 1140

C. sojina, on soybean, QoI fungicide

resistance and, 544, 1347

C. violae, on garden violet, in Serbia, $1035 \mathrm{~N}$

Cerf, I., $1277 \mathrm{~N}$

CERV. See Carnation etched ring virus

Cespedes-Sanchez, M. C., 676

CEVA. See Cyrtanthus elatus virus A

CGMMV. See Cucumber green mottle mosaic virus

Chahin, G., 284N

Chai, A.-L., 1447N

Chalara elegans, on lisianthus, in Switzerland, $1187 \mathrm{~N}$

Chamaecyparis lawsoniana (Port Oxford cedar/ Lawson's cypress), Phytophthora lateralis on, pathogenicity of lineages on different selections, 1133

Chang, X., 699, 725N, 1651N

Chao, S., 1333

Chapara, V., 1434

Chard. See Beta vulgaris var. cicla

Chatterton, S., 288N

Chauhan, R. P., 188, 1695

Chavan, N. S., $1274 \mathrm{~N}$

Chaya. See Cnidoscolus chayamansa

Chen, A. J., 156N

Chen, B. S., 325, 419N

Chen, C., 1241, 1775

Chen, F. X., 1861N

Chen, G., 1775

Chen, G. H., 291N

Chen, G. Q., 1283N

Chen, H., $725 \mathrm{~N}$

Chen, H.-g., 1610

Chen, J., 149, 155N, 219

Chen, J. S., 893N

Chen, J. Y., 1036N

Chen, L. J., 893N, 1289N

Chen, L. L., $1291 \mathrm{~N}$

Chen, P., 1140, 1517

Chen, R. K., 325

Chen, R. R., $1191 \mathrm{~N}$

Chen, S., 1775

Chen, T., 219

Chen, W., 691, 1113, 1446N

Chen, X., 1113, 1704

Chen, X. F., 155N

Chen, X. L., 288N

Chen, X. M., 754, 1500, 1507

Chen, X. R., 281N

Chen, Y., 342

Chen, Y. F., 416N

Chen, Y.-W., 1650N

Chen, Z., 1241

Chen, Z. J., $1273 \mathrm{~N}$

Cheng, B. P., 1283N

Cheng, H. F., 1649N

Cheng, J. S., 1647N

Chennappa, G., 1868N

Cheon, W., 1641N

Cheong, S. S., 162N, 727N, 730N

Cherimoya. See Annona cherimola

Cherry. See Cerasus avium

Chestnut oak, oriental. See Quercus acutissima

Chi, Y. C., 284N, 1448N

Chiang, K.-S., 1104

Chickpea. See Cicer arietinum

Chickpea chlorotic dwarf virus (CpCDV), in tomato, in Pakistan, $1287 \mathrm{~N}$

Chicory. See Cichorium endiva

Chien, M., 1087

Chikoti, P. C., 1290N

Chili pepper. See Capsicum annuum

Chilvers, M. I., 347, 1446N

Chinese banyan. See Ficus microcarpa

Chinese bayberry. See Myrica rubra

Chinese hickory. See Carya cathayensis

Chinese lantern. See Physalis alkekengi 
Chitwood, D. J., 1188N

Chlorophyta, as plant pathogens, 740, Cover photo: Jun

Cho, S., 588

Cho, S. E., $158 \mathrm{~N}, 161 \mathrm{~N}, 162 \mathrm{~N}, 556 \mathrm{~N}, 557 \mathrm{~N}$

$728 \mathrm{~N}, 730 \mathrm{~N}, 731 \mathrm{~N}, 889 \mathrm{~N}, 892 \mathrm{~N}, 1178 \mathrm{~N}$,

$1179 \mathrm{~N}, 1180 \mathrm{~N}, 1185 \mathrm{~N}, 1273 \mathrm{~N}, 1648 \mathrm{~N}$,

$1653 \mathrm{~N}, 1861 \mathrm{~N}, 1863 \mathrm{~N}$

Cho, S.-Y., 897N

Choanephora cucurbitarum

on Hosta plantaginea, in Korea, $158 \mathrm{~N}$

on phlox, in Korea, $1180 \mathrm{~N}$

Choi, G.-S., $1657 \mathrm{~N}$

Choi, H.-S., 292N, 588, 1451N

Choi, I. R., 899N

Choi, I. Y., $161 \mathrm{~N}, 162 \mathrm{~N}, 557 \mathrm{~N}, 727 \mathrm{~N}, 728 \mathrm{~N}$,

$730 \mathrm{~N}, 892 \mathrm{~N}, 1185 \mathrm{~N}, 1273 \mathrm{~N}, 1648 \mathrm{~N}$

Choi, O., 1033N

Choi, S.-K., 1657N

Choi, Y., 727N

Choi, Y.-J., 1643N

Chou, W.-I., 225

Choudhury, R. A., 1866N

Christensen, M. J., 87

Chrysanthemum chlorotic mottle viroid

(CChMVd), in chrysanthemum, in India, 1868N

Chrysanthemum spp.

chrysanthemum chlorotic mottle viroid in, in India, $1868 \mathrm{~N}$

phytoplasma 16SrII-A on, in India, 1641N

Puccinia spp. on

P. chrysanthemi, multiplex real-time PCR assay for, 195

P. horiana: in India, $1279 \mathrm{~N}$; morphology of from naturally infected plants, 1738; multiplex real-time PCR assay for, 195

C. zawadskii var. latilobum, carnation Italian ringspot virus in, in Korea, $1451 \mathrm{~N}$

zucchini yellow mosaic virus in, in China, $1289 \mathrm{~N}$

Chuang, M.-H., 282N

Cibelli, F., 1678

Cicer arietinum (chickpea), Ascochyta spp. on, sensitivity to boscalid, fluxapyroxad, and prothioconazole, 1254

Cichorium spp.

C. endiva (chicory), Physarum cinereum on, in Italy, $1272 \mathrm{~N}$

C. intybus (radicchio), Alternaria alternata on, in Greece, $1867 \mathrm{~N}$

Ciftçi, O., $1866 \mathrm{~N}$

Cinar, A., $553 \mathrm{~N}, 1445 \mathrm{~N}$

Cineraria. See Senecio cruentus

CIRV. See Carnation Italian ringspot virus

Citrullus lanatus (watermelon)

Acidovorax citrulli on, in Serbia, $886 \mathrm{~N}$

Didymella bryoniae on

baseline sensitivity to cyprodinil and fludioxonil of isolates resistant to pyraclostrobin and boscalid, 815 genetic characterization of isolates from Florida and Georgia, 1488

Fusarium brachygibbosum on, in Mexico, $729 \mathrm{~N}$

Fusarium equiseti on, in Georgia, 1272N

Citrus chlorotic dwarf associated virus

$(C C D a V)$, in lemon, in China, $1287 \mathrm{~N}$

Citrus spp.

Alternaria alternata on, in Taiwan, $1864 \mathrm{~N}$

'Candidatus Liberibacter asiaticus' on in Costa Rica, $1855 \mathrm{~N}$

seasonal variations in populations of, 1125 ultrastructural changes and putative phage particles observed in leaves infected with, 320

C. limon (Bureka lemon), citrus chlorotic dwarf associated virus in, in China, $1287 \mathrm{~N}$

C. maxima (pomelo), Fusarium lichenicola on, in Vietnam, $1278 \mathrm{~N}$

C. paradisi (grapefruit), Fusarium oxysporum on, in Turkey, 553N
Penicillium spp. on

fludioxonil resistance in, $1447 \mathrm{~N}$

pathogenicity and host susceptibility, 21

Phytophthora spp. on, potassium phosphite and

heat treatments for management of, 1477

C. reticulata Blanco (tangerine), Alternaria alternata on, sensitivity to boscalid and polymorphism in iron-sulfur and in anchored membrane subunits of succinate dehydrogenase, 231

C. sinensis (Washington navel sweet orange), grafted Carrizo citrange rootstock, citrus viroids and, 125

Spiroplasma citri on, real-time PCR targeting prophage genes of, 149

Xanthomonas citri subsp. citri on, comparison of resistance among different citrus genotypes, 207

Citrus viroids, Washington navel sweet orange grafted on Carrizo citrange and, 125

Cladobotryum protrusum, on Coprinus comatus,

in China, $287 \mathrm{~N}$

Cladosporium spp.

C. cladosporioides H39, for control of Venturia inaequalis on apple, 535

C. fulvum, on tomato, race 0 and race 2 in Argentina, 1732

C. perangustum, on Chinese bayberry, in China, $1283 \mathrm{~N}$

Clark, C. A., 848

Clark, G., 355

Clausena lansium (wampee), Pantoea anthophila on, in China, $416 \mathrm{~N}$

Clavibacter michiganensis

subsp. nebraskensis, on corn in Canada, 1034N in Louisiana, $1268 \mathrm{~N}$

subsp. michiganensis, on tomato, review of, 4 on tomato, Pseudozyma aphidis and induction of salicylic-acid-independence, 621

Claviceps purpurea, on perennial ryegrass, afternoon ascopore release for optimal infection, 1410

Clemens, K., 895N

Clerodendrum trichotomum (glory tree), Coleosporium clerodendri on, in Korea, 1447N

Cloete, M., $1652 \mathrm{~N}$

Clover, G. R. G., 898N

Clover, white. See Trifolium repens

Clustering fishtail palm. See Caryota mitis

CMV. See Cucumber mosaic virus

Cnidoscolus chayamansa (chaya), cassava common mosaic virus in, in Venezuela, $1190 \mathrm{~N}$

Cochliobolus lunatus, on sweet basil, in India, 419N

Cocos nucifera (coconut), Pestalotiopsis spp. on P. adusta, in Brazil, $1036 \mathrm{~N}$

P. menezesiana, in China, $554 \mathrm{~N}$

Codiaeum variegatum (croton), Pseudoidium neolycopersici on, in China, $288 \mathrm{~N}$

Codonopsis lanceolata (bonnet bellflower),

Rhizoctonia solani AG-1-IB on, in China, 1182N

Coker, C. M., 554N

Coleosporium clerodendri, on glory tree, in

Korea, $1447 \mathrm{~N}$

Colletotrichum spp.

C. acutatum

on celery, characterization, virulence, epidemiology, and management of, 1832 on olive, susceptibility of new cultivars, 58

C. asianum, on mango, in South Africa, $725 \mathrm{~N}$

C. coccodes, on potato, extended crop rotations and, 257

C. destructivum, on thyme, in Florida, 1184N

C. fioriniae, on walnut, in China, $289 \mathrm{~N}$

C. gloeosporioides on peach, in South Carolina, 797 on strawberry: identifying resistance to, 954 ; initial inoculum and spatial dispersal of, 80 on sweet viburnum, in China, 1647N
C. godetiae, on avocado, in Mexico, 555N

C. karstii, on blueberry, in Brazil, $157 \mathrm{~N}$

on kenaf, in Korea, $1643 \mathrm{~N}$

C. lentis, on common vetch, in China, $1859 \mathrm{~N}$

C. siamense, on peach and blueberry, resistant to thiophanate-methyl and azoxystrobin, 806

on soybean, multiplex real-time PCR detection and differentiation of, 1559

C. theobromicola, on boxwood, in United States, $1274 \mathrm{~N}$

C. truncatum

on jatropha, in Burkina Faso, 14

sensitivity of to four fungicides, 1590

on soybean, methods and evaluation of soybean for resistance, 143

Collmer, A., 527

Colmer, T. D., 112

Colocasia esculenta (taro),

Ceratocystis fimbriata on, in China, relationship to populations on Eucalyptus in Brazil, 106

Phytophthora colocasiae on, in Turkey, 1445N

Colombian datura virus $(C D V)$, in Chinese lantern, $898 \mathrm{~N}$

Compost, as soil amendment for disease suppression in rooibos seedlings, 1020

Conley, S. P., 1434

Contreras, N., 552N

Cooke, P., 1468

Cooley, D. R., 1526

Copes, W. E., 100, 842, 1390

Copier, Ch., $891 \mathrm{~N}$

Coprinus comatus, Cladobotryum protrusum on, in China, $287 \mathrm{~N}$

Coranson-Beaudu, R., 1640N

Corchorus olitorius (tossa jute), Rhamphicarpa fistulosa on, in Togo, 1654N

Corkrey, R., 50

Corn. See Zea mays

Correll, J. C., 555N

Corynespora cassiicola

on blueberry, in China, 1651N

on eucalyptus, in China, $419 \mathrm{~N}$

on Kerria japonica, $731 \mathrm{~N}$

on kiwifruit, in China, $725 \mathrm{~N}$, Cover photo: May on papaya, in Taiwan, $1649 \mathrm{~N}$

on roselle, in Mexico, 1041N

Cotton. See Gossypium hirsutum

Cottrell, T. E., 916

Cotty, P. J., 1161

Coutts, B. A., 387, 770

Cover crops, for Brassica vegetable crops, Phytophthora capsici and, 1721

Cowpea mild mottle virus (CPMMV), in yardlong bean, in Venezuela, 1657N

Cox, K. D., 1374, 1526, 1751

CpCDV. See Chickpea chlorotic dwarf virus

CPMMV. See Cowpea mild mottle virus

Craig, C. A., 1689

Cranberry, highbush. See Viburnum edule

Crape myrtle. See Lagerstroemia indica

Crataegus pinnatifida (hawthorn), apple chlorotic leaf spot virus in, in China, $164 \mathrm{~N}$

Creeping bentgrass. See Agrostis stolonifera

Crescenzi, A., $1188 \mathrm{~N}, 1272 \mathrm{~N}$

Creswell, T. C., $1278 \mathrm{~N}$

Crinum asiaticum (spider lily), nerine yellow stripe virus in, in India, $1655 \mathrm{~N}$

Croce-Filho, J., 207

Croft, B. J., 93, 1367

Crofton weed. See Eupatorium adenophorum

Cronartium ribicola, impact on resistant cultivated Ribes and neighboring Eastern white pine in New Hampshire, 1374

Crop protection decision process, integrating experience, evidence, and expertise in, 1197

Crosby, K. M., 1656N

Croser, J. S., 1544

Crotalaria spectabilis, Sclerotinia sclerotiorum on, in Brazil, 1037N 
Croton. See Codiaeum variegatum

Crouch, J. A., 195, 1278N

Crous, P. W., $891 \mathrm{~N}$

Crump, N. S., 50, 731N

Cruz, J., 282N

Cruz, L., 282N

Cruz-Izquierdo, S., 1153

Crystal anthurium. See Anthurium crystallinum

CsCMV. See Cassava common mosaic virus

CsFSaV. See Cassava frogskin-associated virus

Cucumber. See Cucumis sativus

Cucumber green mottle mosaic virus (CGMMV)

in Heracleum moellendorffii, in Korea, 897N

in snake gourd, in India, 559N

Cucumber mosaic virus (CMV)

in eggplant, in Bangladesh, 293N

in marigold, in Serbia, $736 \mathrm{~N}$

in Pachysandra terminalis, in United States, $422 \mathrm{~N}$

in peanut, in South Korea, 733N

subgroup II, in heavenly bamboo, $1191 \mathrm{~N}$

Cucumis spp.

C. sativus (cucumber), cucurbit chlorotic yellows virus in, in Saudi Arabia, 734N

C. melo (melon)

Acremonium cucurbitacearum on, in China, $1184 \mathrm{~N}$

Didymella bryoniae on, baseline sensitivity to cyprodinil and fludioxonil of isolates resistant to pyraclostrobin and boscalid, 815

Podosphaera xanthii on, in Korea, 730N

C. trigonus, Fusarium sp. FIESC 17 on, in India, $1274 \mathrm{~N}$

Cucurbit aphid-borne yellows virus (CABYV)

in cucurbits, in Saudi Arabia, 894N

in zucchini, in Libya, $558 \mathrm{~N}$

Cucurbit chlorotic yellows virus (CCYV), in

cucumber, in Saudi Arabia, 734N

Cucurbita spp.

C. pepo

cucurbit aphid-borne yellows virus, watermelon mosaic virus, and zucchini yellow mosaic virus in, in Libya, $558 \mathrm{~N}$

Plectosporium tabacinum on, in North Carolina, $724 \mathrm{~N}$

Serratia marcescens on, in Georgia, $1175 \mathrm{~N}$

zucchini shoestring virus in, In South Africa, $1289 \mathrm{~N}$

zucchini yellow mosaic virus in, transgenic resistance and vertical transmission of, 1616

cucurbit aphid-borne yellows virus in, in Saudi Arabia, 894N

Didymella bryoniae on, genetic characterization of isolates from Florida and Georgia, 1488

C. foetidissima, Pseudoperonospora cubensis on, in North Carolina, $1861 \mathrm{~N}$

Plectosporium tabacinum on, in North Carolina, $724 \mathrm{~N}$

Pseudoperonospora cubensis on, in Michigan, 676

squash vein yellowing virus in, in California, $1042 \mathrm{~N}$

Cudrania tricuspidata, bean common mosaic virus in, in Korea, 292N

Cuellar, W. J., 733N

Cuervo, M., 733N

Cui, B. K., 39

Cui, Y., 699, 725N, 1651N

Cummings, J. A., 1039N, 1284N

Cummings, T. F., 257, 683, 1396

Cunnac, S., 1853N

Cuong, H. V., 1853N

Curry. See Bergera koenigi

Curtobacterium flaccumfaciens pv.

flaccumfaciens, on dry-edible beans in central

high plains of U.S., 1665

Cuscuta spp. (dodder)

C. australis, on Ambrosia artemisiifolia, in China, $1285 \mathrm{~N}$
C. japonica, on Dictamnus dasycarpus, in China, $1285 \mathrm{~N}$

Cvrković, T., $551 \mathrm{~N}$

Cylindrocladium parasiticum, on Medicago sativa, in China, $890 \mathrm{~N}$

CYMV. See Catharanthus yellow mosaic virus

Cynodon dactylon (bermudagrass)

Candidatus Phytoplasma cynodontis on, differentiation based on 16S rRNA and groEL genes and identification of a new subgroup, 16SrXIV-C., 1578

Trichodorus obtusus on, in North Carolina, 291N

Cypress, Leland. See Hesperocyparis macrocarpa $\times$ Callitropsis nootkatensis

Cyprodinil, for Didymella bryoniae on watermelon and muskmelon, resistance against multiple fungicides and, 815

Cyrtanthus elatus virus A (CEVA), in paperwhite, in India, $1658 \mathrm{~N}$

Czajka, A., 729N

Czubatka, A., $729 \mathrm{~N}$

Dababat, A. A., $1280 \mathrm{~N}$

Dactylonectria macrodidyma, on cherimoya, in Chile, $1282 \mathrm{~N}$

Dahlia mosaic virus (DMV), in chili pepper, $898 \mathrm{~N}$

Dai, H., 164N

Dai, Y. C., 39

Dai, Y. L., $1861 \mathrm{~N}$

Dal Bó, E., 1869N

Dallagnol, L. J., 157N

Dally, E. L., 886N, 1087

D'Amato, A. W., 1038N

Damayanthi, M., 1642N

Dami, I., 1087

Dangi, S., 417N

Danilova, T. V., 1317

Dao, S., 551N, 1445N

Dart, N., 1689

Dasheen mosaic virus (DsMV), in lotus, in China, $1449 \mathrm{~N}$

Date palm, Senegal. See Phoenix reclinata

Daucus carota (carrot)

Candidatus Liberibacter solanacearum on, in Germany, $1269 \mathrm{~N}$

Fusarium avenaceum on, in Serbia, 286N

Pseudomonas syringae pv. coriandricola on, in Serbia, $416 \mathrm{~N}$

Thielaviopsis thielavioides on, in Serbia, 1274N

Daughtrey, M. L., 726N

Daugovish, O., 1864N

Davis, D. D., 823, 1070, 1738

Davis, R. E., 886 N, 1087

Davis, R. M., 1713

Davis, V. M., 347

De Araujo Filho, J. V., 157N

De Boer, R. F., 50

De Breuil, S., 735N

De Carvalho Nunes, W. M., 207

De Carvalho, S. A., 207

De Castro Moretti, F. R., 157N

De Koeyer, D., 1658N

De la Rosa, R., 58

De La Torre-Almaráz, R., 899N

De Oliveira, T. S., 157N

De Silva, N., 1642N

De Silva, R., 1642N

De Werra, P., 551N

De Wit, P. J. G. M., 1732

Deadman, M. L., 419N

Deadnettle, hensbit. See Lamium amplexicaule

Deberdt, P., 1640N

Decision process, integrating experience, evidence, and expertise in, 1197

Del Ponte, E. M., 1360, 1859N

Delfosse, P., 1104

Delibašić, G., 709

Delmiglio, C., 898N
Demers, J. E., 195

Demethylation-inhibitor (DMI) fungicides, for

Venturia inaequalis on apple

effect of delayed-dormant chemical treatments on sensitivity to, 1751

prevalence of myclobutanil resistance and difenoconazole insensitivity in populations of, 1526

Dendranthema grandiflora (chrysanthemum), tomato spotted wilt virus in, in India, 1190N

Deng, R. K., 1654N

Deng, T. J., $288 \mathrm{~N}$

Deng, Z. H., 325

Denton, J. O., 898N

Deomano, E. C., 93

Deora, A., 1002

Dervis, S., $1866 \mathrm{~N}$

Detached-leaflet evaluation, for detection of resistance against Phytophthora infestans on tomato, 718

Detweiler, A. R., 1270N

Dewdney, M. M., 231

Dheepa, R., 1279N

Di, Y.-L., 267, 1342

Di Francesco, A., 556N, 1181N

Di Serio, F., $1655 \mathrm{~N}$

Dianthus spp.

D. barbatus (sweet William)

Stolbur phytoplasma on, in Serbia, 283N, Cover photo: Feb

D. caryophylinus (carnation) carnation mottle virus and carnation etched ring virus in, in Mexico, $1191 \mathrm{~N}$

Sclerotinia sclerotiorum on, in India, $1280 \mathrm{~N}$, Cover photo: Sep

Diao, Y., 1449N

Diaphorina citri, on curry, postharvest quarantine treatments for, 916

Diaporthe spp.

D. caulivora, on soybean, in New York, 1039N

D. gulyae, on sunflower, in Canada, $160 \mathrm{~N}$

D. eres, on soybean, in Serbia, $1186 \mathrm{~N}$

Diaz, C., 284N

Diaz, G. A., $888 \mathrm{~N}$

Dickeya spp.

D. dadantii, on sweetpotato, relationships of preharvest weather conditions and soil factors to susceptibility, 848

D. solani, on Hyacinthus orientalis, in China, $155 \mathrm{~N}$

Dickinson, M., $1642 \mathrm{~N}$

Dickison, V., 1658N

Dickson, D. W., 1284N

Dictamnus dasycarpus, Cuscuta japonica on, in China, $1285 \mathrm{~N}$

Dictyosperma album, Pestalotiopsis adusta on, in China, $1040 \mathrm{~N}$

Didymella spp.

D. bryoniae, on watermelon and other cucurbits, baseline sensitivity to cyprodinil and fludioxonil of isolates resistant to pyraclostrobin and boscalid, 815

D. bryoniae, on watermelon and other cucurbits, genetic characterization of isolates from Florida and Georgia, 1488

D. pinodes, on field pea, relative host resistance determination by individual pathogens, 580

Díez, C. M., 58

Difenoconazole, for Venturia inaequalis on apple, insensitivity to, 1526

Dimocarpus longan (longan), Fusarium decemcellulare on, in Puerto Rico, $1187 \mathrm{~N}$

Ding, K., 395

Ding, Y., 1270N

Diospyros kaki (persimmon)

Alternaria alternata on, in Spain, 1416

Eutypella vitis on, in Iran, 1181N

incidence and etiology of postharvest fungal diseases of in Spain, 1416 
Diplodia cupressi, on Leland cypress, in Long Island, NY, 726N

Diplotaxis tenuifolia (wild rocket), Fusarium equiseti on, in Italy, $1183 \mathrm{~N}$

Đisalov, J., 1647N

DMI. See Demethylation-inhibitor fungicides

DMV. See Dahlia mosaic virus

DNA content, pathogen, modeling in potato seed tubers, 50

Doddapaneni, H., 149

Dodder. See Cuscuta spp.

Dodge, S. C., 1204

Doležalová, I., 418N, 892N, 1178N

Doll, D. A., $1185 \mathrm{~N}$

Dolovac, N., 730N

Domínguez, J. C., 1449N

Domfeh, O., 788

Dong, B., $1185 \mathrm{~N}, 1187 \mathrm{~N}$

Dong, L., $1856 \mathrm{~N}$

Dong, L. H., 1192N

Dong, X.-L., 249

Dong, Y., 1654N

Dong, Y. Z., $1288 \mathrm{~N}$

Dong, Z. P., 1856N

Donner, M., 1161

Đorđević, V., 1186N

Dorigo, O. F., $1285 \mathrm{~N}$

Dormant-stage inoculum sanitation, for management of Erwinia amylovora on pear, 1147

Dos S. Paes-Takahashi, V., 1041N

Dossoumou, M. E. E. A., 1640N

Doster, M., 1161

Dothiorella iberica, on almond, in California, $1185 \mathrm{~N}$

Dou, Zh. P., 891N

Douglas fir. See Pseudotsuga menziesii

Doumbia, I., $1445 \mathrm{~N}$

Dowling, M. E., 806

Draper, M., 1176N

Dreo, T., $415 \mathrm{~N}$

DsMV. See Dasheen mosaic virus

Du, D. C., $1283 \mathrm{~N}$

Du, P., 283N

Du, S., 1775

Du, W. F., 283N

Du, X. L., 553N

Du Toit, L. J., 415N, 512, 604, 648

Duan, C. X., 1643N

Duan, H. F., 1287N

Duan, T., 87

Duan, X., 395

Duan, Y., 1241

Duan, Y. X., 290N, 893N

Duduk, B., 1578

Dueñas, M., 1449N

Dufault, N., 1488

Dugan, F. M., 201

Dung, J., 1410

Dunham, J. P., 1616

Duran-Vila, N., 125

Durel, C. E., 370

Durum wheat. See Triticum turgidum

Dutra, D. C., $555 \mathrm{~N}$

Dutta, J., 417N

Dyer, A. T., $1188 \mathrm{~N}$

Dykema, N. M., 1270N

Earnest, J. D., 1616

East African cassava mosaic Malawi virus

(EACMMV), in cassava, in Zambia, $1290 \mathrm{~N}$

Eastwell, K., 176

Ebrahimi, N., 947

Echeveria tolimanensis (Mexican hens),

Fusarium oxysporum f. sp. echeveriae on, in Italy, $1448 \mathrm{~N}$

Edmunds, B. A., 848

Eggplant. See Solanum aethiopicum; Solanum melongena

Egyptian cucumber. See Luffa cylindrica
Ehlenbeck, S., 422N

Eisenback, J. D., 1041N

Eke, S., $1288 \mathrm{~N}$

El-Basyoni, I., 1333

Eleusine coracana (finger millet)

Magnaporthe grisea on, selection of host differentials for elucidating pathogenic variation, 1784

maize chlorotic mottle virus and sugarcane mosaic virus in, in Kenya, 899N

Elkins, R. B., 1147

Elliott, M.L., 887N

Ellison, C. A., 14

Endive, rocket. See Eruca sativa

Engelmann spruce. See Picea engelmanii

Enzenbacher, T. B., 1808

Erginbas-Orakci, G., 1280N

Erickson, A., $1281 \mathrm{~N}$

Erickson, A. C., $1866 \mathrm{~N}$

Erodium moschatum (whitestem filaree),

Podosphaera cf. erodii on, in California, $1866 \mathrm{~N}$

Erskine, W., 1544

Eruca spp.

E. sativa (rocket endive, garden rocket) Albugo candida on, in South Africa, 290N

Physarum cinereum on, in Italy, 1272N

E. vesicaria subsp. sativa (arugula)

Pseudomonas cannabina pv. alisalensis on, in Minnesota, 415N, Cover photo: Mar

Erwinia spp.

E. amylovora, on pear

30 years of management in Israel, 1048

evaluation of dormant-stage inoculum sanitation for management of, 1147

in Finland, 1033N

E. persicina, on garlic, in Europe, $723 \mathrm{~N}$

E. tracheiphila, as classic pathosystem, 564 , Cover photo: May

Erysiphe spp.

E. alphitoides, on Quercus acutissima, in China, $889 \mathrm{~N}$

E. cruciferarum, on rapeseed, in China, $1651 \mathrm{~N}$

E. diffusa

on Wisteria sinensis, in China, 1272N, Cover photo: Sep

E. euonymicola, on wintercreeper, in Korea, $556 \mathrm{~N}$

E. heraclei

on fennel: in California, $1281 \mathrm{~N}$; in Korea, $1185 \mathrm{~N}$

on Hedera helix, in China, $888 \mathrm{~N}$

on Peucedanum japonicum, in Korea, $161 \mathrm{~N}$

E. limonii, on Acantholimon hedinii, in China, $1038 \mathrm{~N}$

E. platani, on London planetree

in Brazil, $157 \mathrm{~N}$

in Greece, $286 \mathrm{~N}$

E. polygoni, on buckwheat, in China, $1282 \mathrm{~N}$

E. trifoliorum, on white clover, in Korea, $1276 \mathrm{~N}$

Eskandari, F. M., 1275N

Esker, P., 418N

Esker, P. D., 347, 1434

Espevig, T., $287 \mathrm{~N}$

Esterio, M., 891N, 1282N

Eucalyptus spp.

E. argophloia and E. cloeziana, Puccinia psidii on, screening for host resistance, 71

Puccinia psidii on, in Australia, 161N

Eucalyptus spp.

Ceratocystis fimbriata on, in Brazil, relationship to populations in China, 106

Corynespora cassiicola on, in China, 419N

Teratosphaeria pseudoeucalypti on, in Argentina, 554N

Eujayl, I. A., 1296

Euoidium longipes, on tamarillo, in New Zealand, $1863 \mathrm{~N}$

Euonymus fortunei var. radicans (wintercreeper), Erysiphe euonymicola on, in Korea, 556N
Eupatorium adenophorum (crofton weed), Meloidogyne hapla on, in China, 1654N

Euphorbia pulchrimma (poinsettia),

Xanthomonas axonopodis on, multilocus sequence analysis for genetic diversity of, 874

European hackberry. See Celtis australis

Eustoma grandiflorum (lisianthus), Chalara elegans on, in Switzerland, 1187N

Eutypella vitis, on persimmon, in Iran, $1181 \mathrm{~N}$

Expert, P., 370

Ezra, D., 496

Förster, H., 1477

Faccoli, M., 1183N

Faedda, R., 1446N

Fagopyrum esculentum (buckwheat)

Erysiphe polygoni on, in China, $1282 \mathrm{~N}$

Peronospora cf. ducometi on, in Czech Republic, $1178 \mathrm{~N}$

Rhizoctonia solani AG4-HG-III on, in China, $1187 \mathrm{~N}$

Fagus sylvatica (beech), Fusarium avenaceum on, in Poland, 420N

Fakhoury, A. M., 544

Fall, M. L., 1010

Faltyn, A., 281N

Fan, F., 1744

Fan, J., 395, 1175N

Fan, S. T., $889 \mathrm{~N}, 1037 \mathrm{~N}, 1644 \mathrm{~N}$

Fan, X., 691

Fanchin, G., 1183N

Fang, L., 1864N

Fanigliulo, A., 1188N, 1272N

Fargette, D., 899N

Farman, M., 1622

Fascetti, S., 1188N

Fayad, Amer, 293N

Feng, C., 555N

Feng, J., 776

Feng, Y.-L., 1285N

Fennel. See Foeniculum vulgare

Fenoglio, J. J., 1865N

Feo, L. Di, 733N

Fernandes, J. M. C., 1360

Fernandes, S. A., 447

Fernando, W. G. D., 1280N

Ferrándiz, J. C., 1175N

Ferrada, E. E., 888N

Ferrari, M. J., 1616

Ferreira, A. P. S., 555N

Ferreira, M. A., 106

Feyissa, B., 1870N

Fichtner, E. J., 1468

Ficus spp.

F. carica (fig), fig mosaic virus in, in China, 422N

$F$. microcarpa (Chinese banyan), Alternaria alternata on, in China, $1652 \mathrm{~N}$

Fieland, V. J., 1326

Fig mosaic virus (FMV), in common fig, in China, $422 \mathrm{~N}$

Filaree, whitestem. See Erodium moschatum

Finger millet. See Eleusine coracana

Fiola, J. A., 1087

Flammulina velutipes (needle mushroom), Acrostalagmus luteo-albus on, in China, $158 \mathrm{~N}$

Fleischer, S. J., 564

Flores, C., $735 \mathrm{~N}$

Flôres, D., 423N

Flores-Moctezuma, H. E., 555N

Florez-Palacios, L., 1140

Fluazinam, for Sclerotinia sclerotiorum on bean, assessment of sensitivity of, 1537

Fludioxonil

for Didymella bryoniae on watermelon and muskmelon, resistance against multiple fungicides and, 815

for Penicillium digitatum on citrus, resistance to, $1447 \mathrm{~N}$ 
for Penicillium expansum on apple, isolates with reduced sensitivity to, $1182 \mathrm{~N}$

Flutriafol, for Sporisorium scitamineum on sugarcane, 1367

Fluxapyroxad, for Ascochyta spp. on pea, lentil, and chickpea, 1254

FMV. See Fig mosaic virus

Foeniculum vulgare (fennel)

Erysiphe heraclei on

in California, $1281 \mathrm{~N}$

in Korea, $1185 \mathrm{~N}$

Pythium sulcatum on, in California, $1645 \mathrm{~N}$

Fonseca, M. E. N., 895N

Font, M. I., $1175 \mathrm{~N}$

Fontaine, F., 1859N

Fontana, A., $1188 \mathrm{~N}$

Foolad, M. R., 718

Fordonski, G., 420N

Four o'clock flower. See Mirabilis jalapa

Fourrier, C., $1277 \mathrm{~N}$

Fox, A. D., 683

Foxtail millet. See Setaria italica

Fragaria $\times$ ananassa (strawberry)

Botrytis cinerea on

population from single field in Germany with complex fungicide resistance pattern, 1076 population structure, fungicide resistance profile, and $s d h b$ mutation frequency, 240

Colletotrichum gloeosporioides on

identifying resistance to, 954

initial inoculum and spatial dispersal of, 80

Franc, G. D., 355

Francis, I. M., 300

Franco, M., 1732

Franco, M. A., 552N

Fraxinus spp. (ash), Verticillium dahliae on, real-time PCR method for detection and monitoring of, 866

Frazier, R., 1268N

Frederick, R., 418N

Frederick, R. D., 1059

Frederick, Z. A., 1751

Freeman, J., 119

French-Monar, R. D., 1187N

Friday, J. B., 1276N

Friebe, B., 1317

Friskop, A., 1333

Friskop, A. J., 1210, 1604

Fritz, A., 1333

Fruit, safeguarding in age of agricultural globalization, 176

Fruk, M., $1181 \mathrm{~N}$

Fry, J. T., 1689

Fry, W. E., 659

Fu, G., 417N

Fu, J., 1285N

Fu, S. M., 320

Fu, Sh.-Y., 1862N

$\mathrm{Fu}, \mathrm{X} . \mathrm{P} ., 734 \mathrm{~N}$

Fu, X.-Y., 1272N

Fu, Y., $1184 \mathrm{~N}$

Fu, Y. P., 1647N

Fuchs, M., 176

Fuji, S., 1823, 1857N

Fujita, Y., 904

Fumonisin, Ustilago maydis on corn and, 1236

Funderburk, J. E., 1450N

Fungicides. See also Demethylation-inhibitor

fungicides; QOI fungicides; SDHI fungicides for Alternaria alternata on peach, fitness and competitive ability of isolates with resistance to, 1744

for Ascochyta spp. on pea, lentil, and chickpea, boscalid, fluxapyroxad, and prothioconazole, 1254

azoxystrobin

for Colletotrichum siamense on peach and blueberry, 806

for control of Rhizoctonia solani on rice, 883 benzothiostrobin, for Sclerotinia sclerotiorum on rape, 969

for Botrytis cinerea

on strawberry, population from single field in Germany with complex fungicide resistance pattern, 1076

on tomato and strawberry and, 240

BP15, for control of Stemphylium vesicarium on pear, 1816

carbendazim

PIRA-PCR for detection of genotypes with resistance alleles in Fusarium fujikuroi on rice, 1241

resistance of Fusarium asiaticum against, 342 Sclerotinia sclerotiorum pathogenicity stimulation by subtoxic doses of, 1342

for Cercospora spp.

C. beticola on sugar beet, PCR-RFLP analysis to monitor fungicide resistance, 355

C. kikuchii on soybean, resistance and, 1596

for Colletotrichum spp.

C. siamense on peach and blueberry, 806

C. truncatum, 1590

on corn, influence of open alleys in field trials assessing yield effects from, 263

for Didymella bryoniae on watermelon and muskmelon, resistance against multiple, 815

fludioxonil

for Didymella bryoniae on watermelon and muskmelon, resistance against multiple fungicides and, 815

for Penicillium digitatum on citrus, resistance to, $1447 \mathrm{~N}$

for Penicillium expansum on apple, isolates with reduced sensitivity to, $1182 \mathrm{~N}$

flutriafol, for control of Sporisorium scitamineum on sugarcane, 1367

for Fusicladium effusum on pecan, effect of sample height on fungicide spray coverage, 916

for leaf blotch diseases in wheat, revisiting management guidelines for, 1434

for Monilinia fructicola on peach, in vitro bioassay for estimating fungicides, 1727

for Penicillium expansum on apple, fludioxonil, isolates with reduced sensitivity to, $1182 \mathrm{~N}$

for Phytophthora infestans

on potato, 659

on tomato, 641

for Pseudoperonospora humuli on hop, preand post-infection activity of, 858

for Puccinia helianthi on sunflower, effect of timing of application, 1210

for Sclerotinia sclerotiorum on bean, assessment of sensitivity of, 1537

sugar beet storage and, 1296

thiophanate-methyl

for Colletotrichum siamense on peach and blueberry, 806

for Sclerotinia sclerotiorum on bean, assessment of sensitivity of, 1537

trifloxystrobin, Fusicladium carpophilum on peach and nectarines and, 467

for Venturia inaequalis on apple, prevalence of myclobutanil resistance and difenoconazole insensitivity in populations of, 1526

Furuya, H., 1823, 1857N

Fusarium spp.

F. acuminatum, on kiwifruit (stored), in China, $1644 \mathrm{~N}$

F. ananatum, on pineapple, in China, $1653 \mathrm{~N}$

F. armeniacum, on balloon flower, in China, $1644 \mathrm{~N}$

F. asiaticum, resistant to carbendazim, in China, 342

F. avenaceum

on Amur grape, $889 \mathrm{~N}$

on beech, in Poland, 420N

on carrot, in Serbia, $286 \mathrm{~N}$

on leek, in California, 1864N
F. boothii

on tomato, in Brazil, $555 \mathrm{~N}$, Cover photo: Apr

$F$. brachygibbosum, on watermelon, in

Mexico, $729 \mathrm{~N}$

$F$. decemcellulare

on longan, mango, and rambutan, in Puerto Rico, $1187 \mathrm{~N}$

on Magnolia denudata, in China, 1036N

F. equiseti

on watermelon, in Georgia, $1272 \mathrm{~N}$

on wild rocket, in Italy, $1183 \mathrm{~N}$

F. flocciferum, on sanqi, in Yunnan, 1650N

F. fujikuroi

on rice, PIRA-PCR for detection of genotypes with carbendazim-resistance alleles, 1241

on soybean, seedborne, In U.S., 1865N

F. graminearum, on foxtail millet, in China, $1856 \mathrm{~N}$

F. graminearum species complex (FGSC) on annual ryegrass, in Brazil, 1859N

on wheat: characterization of strains recovered from symptomatic strains in Kentucky, 1622; following maize or soybean, disease risk, spatial patterns, and disease incidenceseverity relationships, 1360

F. lacertarum, on Casuarina equisetifolia, in Brazil, 1040N

F. lichenicola, on pomelo, in Vietnam, $1278 \mathrm{~N}$

F. oxysporum

on Allard's lavender, in Italy, $1868 \mathrm{~N}$ on Barbados aloe, in Greece, 1649N on Chinese hickory, in China, $1284 \mathrm{~N}$ on grapefruit, in Turkey, $553 \mathrm{~N}$

on pineapple, in Malaysia, $1650 \mathrm{~N}$

$F$. oxysporum $\mathrm{f}$. sp. canariensis on, on date palm, in Florida, $887 \mathrm{~N}$

F. oxysporum $f$. sp. dianthi, phylogenetec relationships among isolates, 780

F. oxysporum f. sp. echeveriae, on Mexican hens, in Italy, $1448 \mathrm{~N}$

F. oxysporum f. sp. spinaciae on, on spinach, soil bioassay for risk prediction, 512

F. oxysporum f. sp. vasinfectum, on cotton, in China, 1569

F. proliferatum on grape, in China, $1180 \mathrm{~N}$ on sunflower, in China, $1275 \mathrm{~N}$

F. pseudograminearum, on wheat, in North China Plain, $156 \mathrm{~N}$

F. redolens, on wheat, in Turkey, $1280 \mathrm{~N}$

$F$. sacchari, on wheat, in China, $160 \mathrm{~N}$

F. solani

on calla lily, in India, $1283 \mathrm{~N}$

on Juglans spp., in Italy, $1183 \mathrm{~N}$

on pineapple, in Malaysia, $1650 \mathrm{~N}$

$F$. sp. FIESC 3, on onion, in Serbia, $1277 \mathrm{~N}$

F. sp. FIESC_17, on Cucumis trigonus, in India, $1274 \mathrm{~N}$

$F$. verticillioides, on ginger, in Brazil, 1177N

$F$. virguliforme, on soybean, cell-free toxic filtrate stem cutting assay for, 502

on soybean, glyphosate and sudden death syndrome, 347

on wheat, survey of in winter wheat growing regions of China, 1610

Fusicladium spp.

F. carpophilum, on peach and nectarine, trifloxystrobin and, 467

F. effusum, on pecan, effect of sample height on fungicide spray coverage, 916

Gätjens-Boniche, O., 1855N

Gálvez, L., 723N

Gómez, J. C., 896N

Gómez-Lama, C., 780

Gaeumannomyces graminis, on Paspalum vaginatum, in China, $1858 \mathrm{~N}$

Gafni, A., 621 
Gager, N., 1727

Gaillardia x grandiflora (blanket flower),

Sclerotinia sclerotiorum on, in Italy, $729 \mathrm{~N}$

Galdames, R., 284N

Galindo-Castro, I., 552N

Galli, M., 155N

Gallou, A., 552N

Galzi-Pinel, A., 899N

Gao, H., 1569

Gao, J., 1180N, 1182N, 1269N, 1644N

Gao, J. Y., 1287N

Gao, L., 442

Gao, L. X., 1647N

Gao, R., $1191 \mathrm{~N}$

Gao, T.-C., 342

Gao, W., $1866 \mathrm{~N}$

Gao, W. W., $156 \mathrm{~N}$

Gao, Z. G., 482

Gao, Z. L., 1870N

Gao, Z. M., 1861N

García, M. C., 894N

García, M. L., 1869N

García-Díaz, M., 723N

García-Jiménez, J., 976

García-Pedrajas, M. D., 780, 1270N

GarCLV. See Garlic common latent virus

Garden rocket. See Eruca sativa

Gardner, J., 727N

Garibaldi, A., 159N, 161N, 162N, 729N, 1037N $1039 \mathrm{~N}, 1183 \mathrm{~N}, 1448 \mathrm{~N}, 1646 \mathrm{~N}, 1650 \mathrm{~N}, 1868 \mathrm{~N}$

Garlic common latent virus (GarCLV), in garlic, in Serbia, 894N

Garlic virus A (GarV-A), in garlic, in India, $1288 \mathrm{~N}$

Garrido, M. J., 1657N

Gaskins, V. L., 1179N, 1182N

Gatch, E. W., 512

Gauthier, N. W., 421N

Gawande, S. J., 1288N

GBNV. See Groundnut bud necrosis virus

Gebreil, A., 1176N

Gebremariam, E. S., 1280N

Geiser, D. M., 1183N

Gent, D. H., 632, 858, 1227

George, S., 1488

Gergerich, R. C., 176

German, S., 1153

Gerrano, A., $1652 \mathrm{~N}$

Gettys, S., 176

Gevens, A. J., 417N, 641

GFkV. See Grapevine virus A

Ghoma. See Solanum macrocarpon

Gibot-Leclerc, S., 1654N

Gilardi, G., 159N, 1183N, 1646N, 1650N

Gilbertson, R. L., 1042N

Gilchrist, L., 284N

Gillespie, T., 310

Gil-Serna, J., 723N

Ginetti, B., 1860N

Ginger. See Zingiber officinale

Ginseng, Asian. See Panax ginseng

Giolitti, F., 735N

Giordano, P. R., 1270N

Girish, A. G., 1784

Giudice, V. Lo, $1446 \mathrm{~N}$

Gleason, M., 310

Gleason, M. L., 564

Globalization, safeguarding fruit in age of, 176 Globodera spp.

G. pallida, optimizing trehalose-based quantification of live eggs in, 947

G. rostochiensis, optimizing trehalose-based quantification of live eggs in, 947

Glomerella cingulata

on apple, effects of temperature, wetness duration, and moisture on, 249

on pear, in China, $553 \mathrm{~N}$

Glory tree. See Clerodendrum trichotomum
GLRaV-1. See Grapevine leafroll-associated virus 1

GLRaV-2. See Grapevine leafroll-associated virus 2

Glycine max (soybean)

16SrII-C subgroup phytoplasma on, in Taiwan, $886 \mathrm{~N}$

bean common mosaic virus in, in Korea, $1189 \mathrm{~N}$

bean pod mottle virus in, effect of time of infection on yield and quality, 1026

Cadophora gregata on, in New York, 1284N

Cercospora spp. on

C. kikuchii: fungicide resistance in, 1596; screening germplasm collection for reaction to stain caused by, 1140

C. sojina, QoI fungicide resistance and, 544, 1347

Colletotrichum spp. on

methods and evaluation of soybean for resistance, 143

multiplex real-time PCR detection and differentiation of, 1559

Diaporthe spp. on

D. caulivora on, in New York, $1039 \mathrm{~N}$

$D$. eres on, in Serbia, $1186 \mathrm{~N}$

Fusarium spp. on

F. fujikuroi on, seedborne, In U.S., $1865 \mathrm{~N}$ glyphosate and sudden death syndrome, 347

$F$. graminearum species complex on wheat following, disease risk, spatial patterns, and disease incidence-severity relationships, 1360

F. virguliforme on, cell-free toxic filtrate stem cutting assay for, 502

Heterodera glycines on, in China, $893 \mathrm{~N}$

Neocosmospora vasinfecta on, in Arkansas, 554N

Phakopsora pachyrhizi on

archaeophytopathology of, 575

comparison of pathogenicity among isolates and identification of resistant soybean genotypes, 1059

in Costa Rica, $418 \mathrm{~N}$

in Malaysia, $420 \mathrm{~N}$

temporal dynamics associated with leaf area index with cultivars of different maturity groups, 1216

Phialophora gregata on, in South Dakota, 1176N

Phomopsis longicolla on

in China, 290N

evaluation of diverse soybean germplasm for resistance to, 1517

Phytophthora sojae on, in China, $1861 \mathrm{~N}$

Pythium sp. on, in North Dakota, 31

Rhamphicarpa fistulosa on, in Togo, 1654N

Glynos, P. E., 723N

Glyphosate, for Fusarium spp. on soybean, sudden death syndrome, 347

Goenaga, R., 1187N

Goji berry. See Lycium barbarum

Golden shower tree. See Cassia fistula

Golino, D., 895N

Golino, D. A., 176

Golovinomyces spp.

G. ambrosiae, on sunflower, in Korea, $557 \mathrm{~N}$

G. biocellatus, on nettleleaf meehania, in Korea, $892 \mathrm{~N}$

G. orontii, on Lactuca serriola, in Korea, $889 \mathrm{~N}$

Golvez. See Colocasia esculenta

Gomes, A. A. M., 555N

Gong, D.-Q., 1653N

Gong, G., 699, 725N, 1651N

González, A., 994

González, A. D., 552N

González-Arcos, M., 895N

González-Casas, A., 1449N

Gopal, J., 1288N

Gopalasamy, G., 1271N

Gordon, T. R., $1864 \mathrm{~N}$

Gorton, C., 1857N
Gossen, B. D., 1002

Gossypium hirsutum (cotton)

Fusarium oxysporum f. sp. vasinfectum on, in China, 1569

tomato leaf curl Gujarat virus in, in Pakistan, $1655 \mathrm{~N}$

Verticillium dahliae on, nondefoliating and defoliating strains correlate with races 1 and 2, 1713

Goto, H., 225

Gottwald, T. R., 926

Gougherty, A. V., 593, 1247

Gourd, ridge. See Luffa acutangula

Grünwald, N. J., 659, 1326

Grabke, A., 797, 806, 1078

Graham, K., 659

Graham, K. A., 1326

Grahovac, M., 709

Granata, G., 1446N

Graney, L., 1274N

Graney, L. S., 1041N

Grape. See Vitis spp.

Grapefruit. See Citrus paradisi

Grapevine fleck virus (GFkV), in grape, in United Kingdom, 898N

Grapevine leafroll-associated virus 1 (GLRaV-1), in grape, in United Kingdom, 898N

Grapevine leafroll-associated virus 2 (GLRaV-2), in muscadine and summer grape, in United States, 163N

Grapevine Pinot gris virus (GPGV), in grapevine, in France, $293 \mathrm{~N}$

Grapevine red blotch-associated virus (GRBaV), in grapevine, in California, $895 \mathrm{~N}$

Grapevine redglobe virus (GRGV), in grapevine, in France, $422 \mathrm{~N}$

Grapevine virus A (GVA), in grape, in United Kingdom, 898N

Graterol, E., 552N

GRBaV. See Grapevine red blotch-associated virus

Greco, B., $1289 \mathrm{~N}$

Green, M., 740

Green, M. J., 886N

Greer, A. M., 554N

Gregg, L., 1656N

Grimova, L., 558N

GroEL genes, differentiation of 'Candidatus Phytoplasma cynodontis' based on, 1578

Groenwold, R., 370

Groundnut bud necrosis virus (GBNV), in Parthenium hysterophorus, in India, 1287N

Grove, G. G., 632

Gryzenhout, M., 725N

Gu, C.-Y., 342

$\mathrm{Gu}, \mathrm{H} ., 1653 \mathrm{~N}$

Gu, J. F., 893N

$\mathrm{Gu}$, Q. S., $1291 \mathrm{~N}$

Gu, Y., $1853 \mathrm{~N}$

Guan, H.-L., 1650N

Guaragna, M. A., 165N

Gubba, A., 1289N

Gubler, W. D., $1281 \mathrm{~N}, 1866 \mathrm{~N}$

Gudmestad, N. C., 164N, 474, 788

Guerra-Camacho, M. A., 729N

Gullino, M. L., 159N, 161N, 162N, 729N, $1037 \mathrm{~N}, 1039 \mathrm{~N}, 1183 \mathrm{~N}, 1448 \mathrm{~N}, 1646 \mathrm{~N}$ $1648 \mathrm{~N}, 1650 \mathrm{~N}, 1868 \mathrm{~N}$

Gulya, T. J., 160N, 1210, 1604

Guo, G., 731N

Guo, J., 1287N

Guo, M. P., 287N

Guo, Q., 325, 1569

Guo, Q. Y., 1643N

Guo, S., 731N

Guo, T. X., 288N

Guo, W.W., $1861 \mathrm{~N}$

Guo, Z. J., 1757

Gupta, S., 417N

Gurav, V. S., 1288N 
Gurung, S., 933, 1404, 1713

GVA. See Grapevine virus A

Gvozdanović-Varga, J., 723N, 736N, 1277N, 1450N

Gynostemma pentaphyllum, Podosphaera xanthii on, in Korea, 1273N

Gynura aurantiaca (purple velvet plant),

Plasmopara halstedii on, in Florida, 1279N

Hüttel, B., 1578

Hébrard, E., 735N

Habibi, A., 1446N

Hackberry, European. See Celtis australis

Haegi, A., 155N

Haematonectria ipomoeae, on sanqi, in China, $1273 \mathrm{~N}$

Hahn, M., 240

Haider, M. S., $1287 \mathrm{~N}$

Halley, S. A., 1210

Ham, L. H., 1853N

Hamaguchi, K., 225

Hambleton, S., 893N

Hameed, U., 1287N

Hamm, P. B., 1410

Hammond, J., 292N

Hamon, H. F., 188

Han, D. J., 754

Han, E. M., $1282 \mathrm{~N}$

Han, H., $162 \mathrm{~N}$

Han, K. S., 158 N, 728 N, 1178N, 1180N, 1273N, $1653 \mathrm{~N}, 1863 \mathrm{~N}$

Han, S., 1652N, 1653N

Han, Z., 939

Handique, P. J., 417N

Handiseni, M., 883

Handoo, Z. A., 1188N

Hansen, E., 1133

Hansen, E. M., 727N

Hansen, J., 1333

Hanson, L. E., 355

Hao, J. J., 291N, 1185N, 1187N

Hao, N., $1277 \mathrm{~N}$

Hao, W., 1477, 1483

Hao, Y., $1177 \mathrm{~N}$

Harakawa, R., 1040N

Harding, M. W., 288N, 1034N

Harijati, N., $1270 \mathrm{~N}$

Harmon, P. F., 557N

Harrington, T. C., 106

Hartman, G. L., 143, 420N, 502, 575, 1059,

Hartung, J., 320

Harveson, R. M., 1604, 1665

Haudenshield, J. S., 420N, 575, 1559

Hausbeck, M. K., 428, 676, 1034N, 1721, 1808, 1832

Hawkins, G., 1658N

Hawthorn. See Crataegus pinnatifida

Hay, F. S., 1227

Hayashi, K., 904

Hayes, R. J., 933, 1404, 1713

He, B. L., $888 \mathrm{~N}$

$\mathrm{He}, \mathrm{H} ., 286 \mathrm{~N}$

He, J., 893N

He, S. H., 39

He, W., $891 \mathrm{~N}$

He, X. H., 1273N

Heavenly bamboo. See Nandina domestica

Hedera helix, Erysiphe heraclei on, in China, 888N

Heerema, R., 1854N

Heerema, R. J., 1468

Hegeman, A. D., 401

Hein, G. L., 1170

Held, B. W., 1038N

Helianthus annuus (sunflower)

Diaporthe gulyae on, in Canada, 160N

Fusarium proliferatum on, in China, 1275N

Golovinomyces ambrosiae on, in Korea, 557N

Plectosphaerella cucumerina on, in China, $1646 \mathrm{~N}$
Puccinia helianthi on

effect of fungicide and timing of application on management of, 1210

phenotypic diversity in U.S. in 2011-2012, 1604

Helichrysum italicum (immortelle),

Macrophomina phaseolina on, in Serbia, 1279N Heller, W. P., $1276 \mathrm{~N}$

Hemicycliophora wyei, on bentgrass, in Texas, $732 \mathrm{~N}$

Hendrickson, P., 1210

Hendry, S., $1857 \mathrm{~N}$

Henne, D. C., 910

Henry, P. M., 1864N

Hensbit deadnettle. See Lamium amplexicaule

Hentges, M., 1037N

Heracleum moellendorffii, cucumber green mottle mosaic virus in, in Korea, 897N

Herbicides, glyphosate, for Fusarium spp. on soybean, sudden death syndrome, 347

Herdina, H., 50

Herman, T. K., 502

Hernández-Arenas, M., $553 \mathrm{~N}$

Hernández-Lauzardo, A. N., 555N

Hernández-Llópis, D., $1175 \mathrm{~N}$

Hernández-Morales, J., 1041N

Hernandez-Gonzalez, J., 552N

Herrera-Foessel, S. A., 508, 1153

Herrmann, H.-W., 1287N

Hershcovich, M., 496

Hershman, D., 1622

Hesperocyparis macrocarpa $\times$ Callitropsis nootkatensis (Leland cypress), Diplodia cupressi on, in Long Island, NY, 726N

Heterobasidion annosum, on red pine, in

Minnesota, $1038 \mathrm{~N}$

Heterodera spp.

H. avenae, on wheat, comparison with

Heterodera filipjevi, 376

$H$. filipjevi, on wheat

comparison with Heterodera avenae, 376 in Montana, $1188 \mathrm{~N}$

H. glycines, on soybean, in China, $893 \mathrm{~N}$

Hevea brasiliensis (rubber tree), Alternaria alternata on, $290 \mathrm{~N}$

Hibiscus spp.

H. cannabinus (kenaf), Colletotrichum sp. on, in Korea, $1643 \mathrm{~N}$

H. sabdariffa (roselle), Corynespora cassiicola on, in Mexico, 1041N

Hickory, Chinese. See Carya cathayensis

Hiemalis begonias. See Begonia $\times$ Hiemalis

Highbush cranberry. See Viburnum edule

Higuera-Ciapara, I., 1590

Hilber-Bodmer, M., 370

Hilje-Rodríguez, I., $1855 \mathrm{~N}$

Hill, C. B., 1059

Hirao, T., 225

Hladky, L. L., 1042N

Ho, B. D., $1278 \mathrm{~N}$

Holb, I. J., 535

Holeva, M. C., 723N

Hollier, C., $1268 \mathrm{~N}$

Holmes, E. C., 1616

Holmes, G. J., 428, 848

Holstein, H. J., 806

Homa, I. H., 558N

Hommes, M., 1269N

Hong, C., 1390, 1689

Hong, J. C., 874

Hong, N., 1704

Hong, N. T., $1853 \mathrm{~N}$

Hong, S. H., 161N, 727N, 889N, 892N, 1179N, $1185 \mathrm{~N}, 1861 \mathrm{~N}$

Hop. See Humulus lupulus

Hordeum vulgare (barley)

Pyrenophora teres f. maculata on, in Idaho, $1860 \mathrm{~N}$

wheat streak mosaic virus in, susceptibility and tolerance of multiple isolates, 1383
Hornbuckle, B., 310

Horseradish. See Armoracia rusticana

Hossain, Md. S., 293N

Hosseini, S., 732N

Host resistance

against Blumeria graminis f. sp. tritici on wheat, new alleles of Pm2 for, 1118

against Botrytis cinerea on strawberry, population from single field in Germany with complex fungicide resistance pattern, 1076

against Ceratocystis fimbriata on mango, induction of the phenylpropanoid pathway by acibenzolar-S-methyl and potassium phosphite and, 447

against Clavibacter michiganensis on tomato, Pseudozyma aphidis and, 621

against Colletotrichum spp.

C. gloeosporioides on strawberry, 954

C. truncatum on soybean, 143

against Cronartium ribicola on Ribes spp., 1374 against Didymella pinodes, Phoma pinodella and $P$. koolunga on pea, determination by individual pathogens, 580

against Magnaporthe oryzae on rice, effects of pyramiding quantitative resistance genes pi21, Pi34, and Pi35 on, 904

against Parastagonospora nodorum and Pyrenophora tritici-repentis on, evaluation and association mapping of, 1333

against Phakopsora pachyrhizi on soybean, comparison of pathogenicity among isolates and, 1059

against Phomopsis longicolla on soybean, evaluation of diverse germplasm for, 1517

against Phytophthora infestans on tomato, detached-leaflet evaluation for, 718

against Plasmodiophora brassicae on

Brassica spp., 776

against Puccinia spp.

$P$. graminis f. sp. tritici on wheat, resistance to Ug99 race group in hybrid derivatives, 1317

$P$. melanocephala on sugarcane, screening for with controlled-conditions inoculation, 1633

P. psidii on Eucalpytus spp., screening for, 71

P. triiformis f. sp. tritici on wheat, $\operatorname{Yr} 60$ gene, 508

$P$. triticina and $P$. striiformis $\mathrm{f}$. tritici on wheat, genetic analysis of, 1153

against Rhizoctonia solani on Brassica spp., cover crop for control of, 883

against Sclerotinia sclerotiorum

on bean, adaptation and common sources of, 1098

Camelina sativa and, 1544

against Verticillium dahliae on pepper, screening of wild and cultivated germplasm for new sources of, 1404

against Xanthomonas citri subsp. citri on citrus, comparison of among different citrus genotypes, 207

against zucchini yellow mosaic virus in Cucurbita pepo, transgenic, vertical transmission and, 1616

Hosta plantaginea, Choanephora cucurbitarum on, in Korea, $158 \mathrm{~N}$

Hot pepper. See Capsicum annuиm

Hotchkiss, M. W., 916

Hou, Y., 969, 1241

Houngbédji, T., 1654N

Howard, R. J., 1034N

Hoy, J. W., 1633

Hrustić, J., 709

Hsiang, T., $288 \mathrm{~N}$

Hsu, Z. H., 1649N

$\mathrm{Hu}$, B., $1175 \mathrm{~N}$

Hu, F. Y., 417N, 1645N

$\mathrm{Hu}, \mathrm{L} ., 1184 \mathrm{~N}$

Hu, M.-J., 797, 806

Hu, R., 699 
Hu, T. L., 553N

Hu, X., 933, 1404, 1689, 1713

Hu, X. R., $1283 \mathrm{~N}$

Hu, Y. D. X. Q., 557N

Hu, Z. L., $1270 \mathrm{~N}, 1449 \mathrm{~N}$

Huang, C. J., 164N, 733N

Huang, C. W., 1864N

Huang, H. C., 1649N

Huang, J., 1483

Huang, J. B., 1036N

Huang, L., 1113

Huang, L. L., 754

Huang, P., 1652N

Huang, Q., 106, 333

Huang, S. L., $159 \mathrm{~N}$

Huang, S. P., 288N

Huang, S.-L., 160N

Huang, X. Y., $1645 \mathrm{~N}$

Huanglongbing. See Candidatus Liberibacter africanus; Candidatus Liberibacter americanus; Candidatus Liberibacter asiaticus

Huat, J., 1640N

Huerta-Espino, J., 508, 1153

Hughes, G., 1197

Hughes, M. E., 1261

Hughes, R. F., 1276N

Humann, R. M., 1604

Humulus lupulus (hop)

Podosphaera macularis on, critical period for management of, 632

Pseudoperonospora humuli on, pre- and postinfection activity of fungicides for control of, 858

Hwang, S.-F., 776

Hyacinthus orientalis, Dickeya solani on, in China, $155 \mathrm{~N}$

Hyde, K. D., 725N

Iacovides, T., $1648 \mathrm{~N}$

Ibáñez, I., $1175 \mathrm{~N}$

Ibaba, J. D., 1289N

Ibarra, A. G., $415 \mathrm{~N}$

Ibrahim, N. F., 1650N

Idesia polycarpa, Alternaria alternata on, in China, $1177 \mathrm{~N}$

Igarashi, Y., 1857N

Ignjatov, M., $416 \mathrm{~N}, 723 \mathrm{~N}, 724 \mathrm{~N}, 730 \mathrm{~N}, 736 \mathrm{~N}$, $896 \mathrm{~N}, 1033 \mathrm{~N}, 1277 \mathrm{~N}, 1450 \mathrm{~N}$

Ignjatov, M., $1869 \mathrm{~N}$

Ilyonectria spp.

I. liriodendri, on grape, in Turkey, $1855 \mathrm{~N}$

I. robusta, on Asian ginseng, in China, $156 \mathrm{~N}$ Immanuel, T. M., 898N

Immortelle. See Helichrysum italicum

Impatiens walleriana

Plasmopara obducens on, in North Dakota, $1039 \mathrm{~N}$

Rhizoctonia solani AG4-HG-I on, in China, $1653 \mathrm{~N}$

Ingels, C. A., 1147

Ingle, A. A., $1288 \mathrm{~N}$

Inoue, K., 409

Ioos, R., $1277 \mathrm{~N}$

Ipomoea batatas (sweetpotato)

Rhizopus stolonifer and Dickeya dadantii on, relationships of preharvest weather conditions and soil factors to susceptibility, 848

sweetpotato symptomless virus 1 in, in China, $1042 \mathrm{~N}$

Iqbal, M. J., $1287 \mathrm{~N}$

Iqbal, Z., $1655 \mathrm{~N}$

Iresine viroid 1 (IrVd-1), in ornamental plants and Celosia cristata, in Italy, $1655 \mathrm{~N}$

Irrigation, Verticillium dahliae on olive and, 488 Itersonilia perplexans, on dill, in Cyprus, $1648 \mathrm{~N}$ Ito, D., 1383

Ito, D. S., $1285 \mathrm{~N}$

Ivanović, Ž., $281 \mathrm{~N}, 416 \mathrm{~N}, 723 \mathrm{~N}, 724 \mathrm{~N}, 730 \mathrm{~N}$, $886 \mathrm{~N}, 1033 \mathrm{~N}, 1274 \mathrm{~N}, 1277 \mathrm{~N}$
Ivors, K. L., 1550

Ivy, Swedish. See Plectranthus verticillatus Iwasa, A., 1823

Jabbari Firoozjah, M., 1181N

Jackfruit. See Artocarpus heterophyllus

Jakovljević, M., 551N

Jakubska-Busse, A., 281N

James, D., 558N

Janardhana, G. R., 1280N, 1641N

Janssen, D., 894N

Japanese oak. See Quercus serrata

Japanese plum. See Prunus salicina

Jarroudi, M. El, 1104

Jarzembowski, P., 281N

Jatropha curcas (jatropha), Colletotrichum truncatum on, in Burkina Faso, 14

Jaureguy, L., 1140

Jawaharlal, M., 1190N

Jayaro, Y., $552 \mathrm{~N}$

Jemelková, M., 892N, 1178N

Jemric, T., $1181 \mathrm{~N}$

Jeon, Y., $1641 \mathrm{~N}$

Jeon, Y. H., 897N

Jesse, L. C. H., 564

Jesus Júnior, W. C., 1216

Ježewska, M., $1290 \mathrm{~N}$

Ji, P., 1272N

Jia, M. J., $1269 \mathrm{~N}$

Jia, Z.-W., 1653N

Jiang, D., 1426

Jiang, N., $417 \mathrm{~N}, 1645 \mathrm{~N}$

Jiang, Q. W., 355

Jiang, Sh. Y., $1645 \mathrm{~N}$

Jiang, W.-T., 888N, 1272N, 1862N

Jiang, X., 1182N

Jiang, Y., 1184N

Jiao, X. L., 156N

Jibrin, M. O., $415 \mathrm{~N}$

Jifon, J. L., 1656N

Jiménez-Díaz, R. M., 962

Jiménez-Fernández, D., 962

Jin, Z., $731 \mathrm{~N}$

Jing, L., 291N, 1275N

Jo, Y.-K., 883

Joa, J. H., $162 \mathrm{~N}$

Johnson, A. M. A., 1287N

Johnson, B. J., 1236

Johnson, D., 422N

Johnson, D. A., 257, 683, 1087, 1396

Johnson, K. B., 1147

Johri, J. K., 1189N

Jointleaf rush. See Juncus articulatus

Jones, J. B., 415N, 874

Jones, L. A., 527

Jones, R. A. C., 387, 770

Joosten, M., 886N

Jordahl, J. G., 1210

Jordan, R., $165 \mathrm{~N}$

Jordan, S. A., 641

Jørgensen, H. J. L., $1278 \mathrm{~N}$

Josic, D., 283N

Jović, J., $551 \mathrm{~N}, 1035 \mathrm{~N}, 1274 \mathrm{~N}, 1645 \mathrm{~N}$

Jovičić, D., 896N, 1869N

Juglans spp.

J. cinerea (butternut)

Ophiognomonia clavigignentijuglandacearum on: influence of temperature and humidity on conidia viability, 1841; inhibition by Juglans spp. bark extracts, 401

Fusarium solani on, in Italy, 1183N

J. regia (walnut), Colletotrichum fioriniae on, in China, 289N

Jujube. See Ziziphus jujuba

Juncus articulatus (jointleaf rush), 'Candidatus

Phytoplasma asteris' on, in Poland, 281N

Jurick II, W. M., 1179N, 1182N

Jute, tossa. See Corchorus olitorius
Köhl, J., 535

Kahono, S., 225

Kaiser, M. S., 1247

Kaiser, W. J., 1446N

Kalantarzadeh, M., 1857N

Kallsen, C., 1468

Kalmegh. See Andrographis paniculata

Kalonji Kabengele, J. B., 290N

Kamata, N., 225

Kamble, S. S., 1274N

Kamenidou, S., 176

Kamran, A., 894N

Kanatiwela-de Silva, C., 1642N

Kandel, Y. R., 347

Kanetis, L., 1648N, 1867N

Kang, M., 292N

Kang, Y. B., 890N

Kang, Z., 1113

Kang, Z. S., 754

Karafla, C. D., $723 \mathrm{~N}$

Karakaya, A., $1280 \mathrm{~N}$

Karantemiris, K., 1867N

Karaoglanidis, G., 240

Kariyawasam, G., 1333

Karthikeyan, A., 442

Karthikeyan, G., 558N, 559N, 1190N

Kasson, M. T., 823, $1183 \mathrm{~N}$

Katis, N. I., 734N, 894N

Kaur, C., $897 \mathrm{~N}, 1655 \mathrm{~N}, 1658 \mathrm{~N}$

Kavroulakis, N., 1649N, 1867N

Kawaguchi, A., 409

Kawchuk, L. M., 1034N

Ke, W. D., 1270N

Kefialew, Y. W., 1488

Keinath, A. P., 428, 815

Keiser, A., $551 \mathrm{~N}$

Keith, L. M., 1276N

Kenaf. See Hibiscus cannabinus

Kern-asa, O., 225

Kerns, J., 291N, 982

Kerria japonica, Corynespora cassiicola on, $731 \mathrm{~N}$

Khamis, F., 899N

Khan, A., $155 \mathrm{~N}, 292 \mathrm{~N}$

Khan, T. N., 580

Khrfan, W. I., $1286 \mathrm{~N}$

Khureshi, C. S. M., $1287 \mathrm{~N}$

Kielsmeier-Cook, J., 1317

Kil, E.-J., 588

Kilcrease, J., 1468

Kim, B. S., $158 \mathrm{~N}, 557 \mathrm{~N}, 1861 \mathrm{~N}, 1863 \mathrm{~N}, 1865 \mathrm{~N}$

Kim, C.-S., 588

Kim, J., 1033N, 1643N

Kim, J. H., $727 \mathrm{~N}$

Kim, J. Y., $1861 \mathrm{~N}, 1865 \mathrm{~N}$

Kim, J.-S., 733N

Kim, M.-K., 292N, 1451N

Kim, S., 588

Kim, W., $1446 \mathrm{~N}$

Kim, W.-I., $1033 \mathrm{~N}$

Kim, Y. H., 1447N

Kim, Y. K., 201, 1447N

Kim, Y. S., 897N, 1640N

Kimunye, J. N., $1870 \mathrm{~N}$

Kinzer, K., 1039N, 1860N

Kirk, W. W., 355, 417N

Kirkpatrick, S. C., 1864N

Kirschne, R., $726 \mathrm{~N}$

Kirshner, B., 496

Kitajima, E. W., 423N

Kitner, M., 418N, 892N, 1178N

Kiwi. See Actinidia chinensis

Klebsiella pneumonia, on onion, in China, 1853N

Knaus, B. J., 1326

Ko, S.-J., 292N

Kodama, F., $1857 \mathrm{~N}$

Koebnik, R., 1853N

Koike, S. T., 555N, 933, 1281N, 1645N, 1864N

Koita, O., 551N, 1445N 
Koizumi, S., 904

Kojic, S., 283N

Kolmer, J. A., 156N, 1261

Kone, D., $1445 \mathrm{~N}$

Kong, J., 735N, 1191N

Kong, X. Y., 1642N

Konjac, Phytophthora nicotianae on, in China, $283 \mathrm{~N}$

Konstantinou, S., 240

Korsten, L., 21

Kosawang, C., 1278N

Kosman, E., 1410

Kosovac, A., $551 \mathrm{~N}$

Kosto, I., 496

Kouadio, L. A., 1104

Kousik, C. S., 676

Koutou, M., 732N

Krasnow, C. S., 1721

Krishnapillai, N., 1858N

Krstić, B., 709, 736N, 894N, 896N, 1869N

Krstić, O., 551N

Krstic, B., 286N

Kube, M., 1578

Kumar, A., 419N

Kumar, S., 627, 897N, 1189N, 1655N, 1658N

Kumari, A., 897N, 1189N

Kumquat, Candidatus Phytoplasma asteris on, in Mexico, 552N

Kunta, M., 910

Kunwar, S., 119

Kusia, E. S., 899N

Kusumoto, D., 225

Kvalbein, A., $287 \mathrm{~N}$

Kvarnheden, A., 732N

Kwak, H.-R., 292N, 1451N

Kwon, J.-H., 1640N, 1643N

López-Escudero, F. J., 488

Lactuca serriola, Golovinomyces orontii on, in Korea, $889 \mathrm{~N}$

Lagerstroemia indica (crape myrtle),

Meloidogyne mali on, in Japan, 893N

Lagudah, E. S., 508

Lahoz, E., $1272 \mathrm{~N}$

Lai, X. P., $1287 \mathrm{~N}$

Laing, M. D., 1289N

Lal, R. K., 419N

Lalancette, N., 467, 1727

Lambertella corni-maris, on apple, in

Washington state, 201

Lamb's lettuce. See Valerianella olitoria

Lamium amplexicaule (hensbit deadnettle),

Neoerysiphe galeopsidis on, in Korea, $1179 \mathrm{~N}$

LaMondia, J. A., 363

Lamprecht, S. C., 1020

Lamprou, K., 1649N, 1867N

Lan, C. X., 508, 1153

Lan, C. Z., $1652 \mathrm{~N}$

Lane, T., $1188 \mathrm{~N}$

Lantos, A., $556 \mathrm{~N}$

Laphilliph, P. J., 726N

Larignon, P., 1859N

Lasiodiplodia spp.

L. jatrophicola

on clustering fishtail palm, in China, 1038 N, Cover photo: Jul

L. theobromae, on golden shower tree, in China, $288 \mathrm{~N}$

Latorre, B. A., $888 \mathrm{~N}$

Latuca sativa (lettuce)

Bremia lactucae on, impacts of weather on infection efficiency, 1010

lettuce corky blight on, 300

Physarum cinereum on, in Italy, $1272 \mathrm{~N}$

Verticillium klebahnii and V. isaacii on, host range of, 933

Laurel oak, seeQuercus laurifolia

Lava Kumar, P., 886N
Lavandula spp.

L. $\times$ allardii (Allard's lavender), Fusarium oxysporum on, in Italy, $1868 \mathrm{~N}$

L. stoechas (butterfly lavender), Rhizoctonia solani AG 1 - IB on, in Italy, 1039N

Lawson's cypress. See Chamaecyparis lawsoniana

LChV-1. See Little cherry virus 1

León, M., 976

Leaf area index, Phakopsora pachyrhizi on soybean and, temporal dynamics associated with cultivars of different maturity groups, 1216

Leaf Doctor, a new portable application for quantifying plant disease severity, 1310, Cover photo: Oct

Leaf wetness, duration determination for plant disease management, 310

Lebeda, A., 418N

LeBoldus, J., 1039N

Lebsky, V., 552N

LeDoux, D. G., 1087

Lee, C., 263

Lee, C. K., $556 \mathrm{~N}, 731 \mathrm{~N}$

Lee, D. J., 71

Lee, H. B., $889 \mathrm{~N}, 1276 \mathrm{~N}$

Lee, I.-M., 1087

Lee, J.-Y., $1640 \mathrm{~N}$

Lee, K.-Y., 588

Lee, M.-A., 733N

Lee, S., 588, $1641 \mathrm{~N}$

Lee, S. H., 556N, 731N, $1447 \mathrm{~N}$

Lee, S. K., $556 \mathrm{~N}$

Lee, S.-D., $1643 \mathrm{~N}$

Lee, S.-H., 733N, 1189N

Lee, S.-T., $1643 \mathrm{~N}$

Lee, W. H., 727N

Lee, Y.-H., $1189 \mathrm{~N}$

Lee, Y.-K., 1640N

Leek. See Allium porrum

Legg, J. P., 1290N

Lehman, B., $1179 \mathrm{~N}$

Lehner, M. S., 1098, 1537

Lehnhoff, E., 1383

Lehnhoff, E. A., 1803

Leke, W. N., 732N

Leland cypress. See Hesperocyparis macrocarpa $\times$ Callitropsis nootkatensis

Lemaire, O., $293 \mathrm{~N}, 422 \mathrm{~N}$

Lemon, Bureka. See Citrus limon

Lemon verbena. See Lippia citriodora

Lenardon, S., $735 \mathrm{~N}$

Lens culinaris (lentil), Ascochyta spp. on, sensitivity to boscalid, fluxapyroxad, and prothioconazole, 1254

León, L., 58

Leptosphaeria spp.

L. biglobosa, on oilseed rape, effect of water flooding on survival in stubble, 1426

L. maculans, on oilseed rape, effect of water flooding on survival in stubble, 1426

Leroch, M., 240

Leucadendron spp. (proteas), Phytophthora cinnamomi on, in Turkey, $1181 \mathrm{~N}$

Leveillula taurica, on spinach, in California, $555 \mathrm{~N}$

Levy, M., 621

Lewis, A., $1857 \mathrm{~N}$

Leyva-Mir, S. G., 553N

Li, B. L., $733 \mathrm{~N}$

Li, B.-H., 249

Li, B.-J., $1447 \mathrm{~N}$

Li, C. H., $1282 \mathrm{~N}$

Li, C. W., $1862 \mathrm{~N}$

Li, D. W., $1036 \mathrm{~N}$

Li, F., 734N, 776

Li, G., 219, 691, 1426

Li, G. F., 735N, $1191 \mathrm{~N}$

Li, G. H., $290 \mathrm{~N}$

Li, G. Q., 283N

Li, H., $1118,1277 \mathrm{~N}$

Li, H. L., $1291 \mathrm{~N}$
Li, J. X., 1287N

Li, J.-L., 267

Li, K., 442

Li, M., $1646 \mathrm{~N}, 1651 \mathrm{~N}$

Li, N., 283N

Li, P.-F., 1488

Li, P.-Q., 289N

Li, Q. L., $288 \mathrm{~N}$

Li, Q. Q., 725N

Li, R., 163N

Li, R. H., 734N

Li, S., 1140, 1483, 1517, 1569

Li, S. F., 422N, $1191 \mathrm{~N}$

Li, S. J., $159 \mathrm{~N}$

Li, W., 1584, 1610

Li, X. H., 1657N

Li, Y., $888 \mathrm{~N}, 1272 \mathrm{~N}, 1856 \mathrm{~N}, 1862 \mathrm{~N}$

Li, Y. H., $156 \mathrm{~N}$

Li, Y. P., 112

Li, Y. Y., 734N, 1287N

Li, Y. Z., 1859N

Li, Z. A., 320

Li, Z. H., $1861 \mathrm{~N}$

Li, Z. Y., 1856N

Li Destri Nicosia, M. G., 44

Liang, C., 289N

Liang, H.-J., 267

Liang, J., 1764

Liang, X., 969

Liang, Y., $1187 \mathrm{~N}, 1646 \mathrm{~N}$

Liang, Y. C., $1177 \mathrm{~N}, 1288 \mathrm{~N}$

Liang, Z., 1658N

Liao, L. S., $416 \mathrm{~N}$

Liao, W. J., $289 \mathrm{~N}$

Licht, M. A., 347

Lichtemberg, P. S. F., 1161

Ligoxigakis, E. K., $286 \mathrm{~N}$

Lilac. See Syringa 'Charisma'

Lilium spp., plantago asiatica mosaic virus in in Hungary, $1288 \mathrm{~N}$

in Italy, $1289 \mathrm{~N}$

in United States, 292N

Lily, calla. See Zantedeschia ellitiona

Lily, spider. See Crinum asiaticum

Lim, S., $1189 \mathrm{~N}$

Lima, R. C., 1098

Lin, C.-H., $282 \mathrm{~N}$

Lin, Q.-L., 286N

Lin, S. H., $159 \mathrm{~N}$

Lin, S.-H., 160N

Lin, W., $725 \mathrm{~N}$

Lin, W. W., $1189 \mathrm{~N}$

Lin, Z., 1176N

Lin, Z. Y., 325

Lindeberg, M., 527

Lindow, S. B., 1147

Ling, K.-S., $163 \mathrm{~N}$

Lippia citriodora (lemon verbena), Ulocladium chartarum on, in Iran, $1186 \mathrm{~N}$

Lisianthus. See Eustoma grandiflorum

Little, C. R., $1865 \mathrm{~N}$

Little, E. L., $1175 \mathrm{~N}$

Little cherry virus 1 (LChV-1), in sweet cherry, in China, $1191 \mathrm{~N}$

Liu, C., 1483

Liu, D. Q., $1035 \mathrm{~N}$

Liu, F., 419N

Liu, G. K., 420N

Liu, G. S., 1192N

Liu, H. B., $1192 \mathrm{~N}$

Liu, H. X., $888 \mathrm{~N}, 1288 \mathrm{~N}$

Liu, J., 219, 888N, 898N, 1190N

Liu, L., 554N, 1038N, 1040N, 1856N

Liu, L. L., $156 \mathrm{~N}$

Liu, M., 1657N

Liu, N., 699

Liu, Q.-G., $1268 \mathrm{~N}$

Liu, S., $1651 \mathrm{~N}, 1853 \mathrm{~N}$

Liu, S. Y., 416N 
Liu, Sh.-Y., 888N, 1272N, 1856N, 1862N

Liu, T. F., $1861 \mathrm{~N}$

Liu, W.-A., $726 \mathrm{~N}$

Liu, X., 482

Liu, X. Q., 284N

Liu, X. Y., $893 \mathrm{~N}$

Liu, X.-M., $288 \mathrm{~N}$

Liu, Y., 164N, 733N, 898N, 1190N, 1642N

Liu, Y. H., $1284 \mathrm{~N}$

Liu, Y. J., 553N, 1864N

Liu, Y. X., 290N, 889N, 1037N, 1644N

Liu, Y. Y., 1189N

Liu, Z., 1333

Llorente, I., 1816

Lobato-Ortiz, R., 1153

Lockhart, B., 165N, 422N

Locoweed, spotted. See Astragalus lentiginosus

Lojkowska, E., $1271 \mathrm{~N}$

Lolium spp.

L. multiflorum (annual ryegrass), Fusarium graminearum species complex (FGSC) on, in Brazil, 1859N

L. perenne (perennial ryegrass) Claviceps purpurea on, afternoon ascopore release for optimal infection, 1410

Xanthomonas translucens on, in United States, $1270 \mathrm{~N}$

London planetree. See Platanus $\times$ acerifolia

Lonergan, E., 1254

Long, H. B., $1868 \mathrm{~N}$

Long, Y. J., 1273N

Longan. See Dimocarpus longan

Lookabaugh, E. C., 1550

Loosestrife, purple. See Lythrum salicaria

Loper, J. E., 1642N

Lopez, M. P. B., 1648N

Lopez, P., 1279N

Lops, F., 1678

Lorite, I. J., 488

Lotus. See Nelumbo nucifera

Louw, J. P., 21

Louws, F., 80

Lu, B. H., 1269N, $1644 \mathrm{~N}$

Lu, G., 1483

Lu, L. M., $1283 \mathrm{~N}, 1652 \mathrm{~N}$

Lu, M. G., $1191 \mathrm{~N}$

Lu, W. J., $1282 \mathrm{~N}$

Lu, X., 1569

Lu, X. H., $156 \mathrm{~N}$

Lu, X.-M., 1342

Lu, Y. Y., $290 \mathrm{~N}$

Lu, Z., $1285 \mathrm{~N}$

Luchsinger, N., 284N

Luffa spp.

L. acutangula (ridge gourd), zucchini

yellow mosaic virus in, in Pakistan, $1870 \mathrm{~N}$

L. cylindrica, Podosphaera xanthii on, in Korea, $1861 \mathrm{~N}$

Lujan, P. A., 891N

Luo, C., 1775

Luo, C. X., 1744

Luo, F., $1642 \mathrm{~N}$

Luo, J. T., $419 \mathrm{~N}$

Luo, X., 898N

Luo, X. W., $1190 \mathrm{~N}$

Luo, Y., 156N, 395, 1764

Luohanguo. See Siraitia grosvenorii

Luongo, L., $155 \mathrm{~N}$

Lv, H. Y., 889N, 1037N, 1644N

Lv, M., $1853 \mathrm{~N}$

Lychnis coronaria (rose campion)

Rhizoctonia solani AG 1-IB on, in Italy, $162 \mathrm{~N}$, Cover photo: Jan

Lycium barbarum (goji berry), Arthrocladiella

mougeotii on, in China, $1283 \mathrm{~N}$

Lycopersicon esculentum (tomato). See Solanum

lycopersicum

Lynn, J., 1034N
Lythrum salicaria (purple loosestrife),

Zasmidium lythri on, in Korea, $728 \mathrm{~N}$

Möller, P. A., 1859N

Ma, J., 735N, 1191N

Ma, J. J., 1644N

Ma, P., 1569

Ma, W. J., 159N

Ma, X., 732N

Ma, Y., 1569

Ma, Z., 1764

Machado, A. C. Z., $1285 \mathrm{~N}$

Machado, A. R., 555N, 1036N

Machado, F. J., 1859N

Machado, M. A., 207, 1125

Maciel, C. G., 1040N

Mackels, C., 1104

Mackie, A. E., 770

Macrophomina phaseolina

on immortelle, in Serbia, 1279N

on sugarcane, in Mexico, 553N

Madata, C. S., 886N

Madden, L. V., 1434

Maeso, D., 895N

Magnaporthe spp.

M. grisea, on finger millet, selection of host differentials for elucidating pathogenic variation, 1784

M. oryzae

on rice: detection using real-time PCR, 219; effects of pyramiding quantitative resistance genes pi21, Pi34, and Pi35 on, 904 on wheat, in Argentina, $1177 \mathrm{~N}$

Magnolia denudata, Fusarium decemcellulare on, in China, $1036 \mathrm{~N}$

Mahadevakumar, S., 1280N, 1641N

Maheshwar, P. K., 1868N

Mahuku, G., 1870N

Maize chlorotic mottle virus (MCMV)

in finger millet, in Kenya, 899N

in maize, in Ethiopia, 1870N

Malathi, V. G., $1190 \mathrm{~N}$

Mali, A. M., 1274N

Mallik, I., 164N

Malus spp. (apple)

M. $\times$ domestica

Glomerella cingulata on, effects of temperature, wetness duration, and moisture on, 249

Lambertella corni-maris on, in Washington state, 201

Monilinia spp. on: $M$. fructicola, in Pennsylvania, $1179 \mathrm{~N} ;$ M. polystroma , in Croatia, $1181 \mathrm{~N}$

Penicillium expansum on, isolates with reduced sensitivity to fludioxonil, $1182 \mathrm{~N}$

Venturia inaequalis on: Cladosporium cladosporioides $\mathrm{H} 39$ for control of, 535; prevalence of myclobutanil resistance and difenoconazole insensitivity in populations of, 1526

M. pumila, Pseudomonas syringae pv. syringae on, in Korea, $1641 \mathrm{~N}$

Venturia inaequalis on

Cladosporium cladosporioides $\mathrm{H39}$ for control of, 535

effect of delayed-dormant chemical treatments on demethylation inhibitor sensitivity, 1751

prevalence of myclobutanil resistance and difenoconazole insensitivity in populations of, 1526

virulence of reference isolates on different hosts, 370

Mamiro, D. P., 1035N, 1854N

Mandevilla spp.

catharanthus mosaic virus in, in United States, $165 \mathrm{~N}$

M. sanderi, Pseudomonas savastanoi, in Slovenia, $415 \mathrm{~N}$

Mangandi, J., 954
Mangifera indica (mango)

Ceratocystis fimbriata on, induction of the phenylpropanoid pathway by acibenzolarS-methyl and potassium phosphite increases resistance to, 447

Colletotrichum asianum on, in South Africa, $725 \mathrm{~N}$

Fusarium decemcellulare on, in Puerto Rico, 1187N

Micrococcus luteus on, in India, 1640N

Neofusicoccum mediterraneum on, in Sri Lanka, $1858 \mathrm{~N}$

Xanthomonas citri pv. mangiferaeindicae on, in Benin, 1854N

Mangwende, E., 290N

Mani, C., 1268N

Mano, E. T., $1642 \mathrm{~N}$

Manoranjitham, S. K., 558N, 559N

Mansoor, S., 1655N

Mansour, A. N., $1286 \mathrm{~N}$

Manulis-Sasson, S., 1048

Mao, J. J., 1192N

Mao, Z. S., 1273N

Maple, sugar. See Acer saccharum

Maple, trident. See Acer buergerianum

Marais, F., 1333

Mari, M., 556N, $1181 \mathrm{~N}$

Marjanović-Jeromela, A., 896N, 1869N

Markakis, E. A., 286N

Markell, S. G., 160N, 1210, 1604

Marois, J., 1488

Marshall, J. M., 1860N

Martín, A. B., $1449 \mathrm{~N}$

Martin, A. C., 401

Martin, F., $1645 \mathrm{~N}$

Martin, M., 982

Martin, R. C., 1410

Martin, R. R., 176, 421N

Martin, S., 982

Martinez, I., $1177 \mathrm{~N}$

Martini, C., 556N, 1181N

Martin-Mex, R., 1590

Marys, E., 896N, 1190N

Masny, S., 535

Massimino Cocuzza, G. E., 1446N

Masuya, H., 225

Mathew, F., $1176 \mathrm{~N}$

Mathew, F. M., 160N

Maurice, I., $421 \mathrm{~N}$

Mayor, E., $1449 \mathrm{~N}$

Mays, E., 1657N

Mazzola, M., 1020

MBC fungicides, for Alternaria alternata on peach, fitness and competitive ability of isolates with resistance to, 1744

McAvoy, T., 119

McCreight, J. D., 1042N

McDonald, M. R., 1002

McFarland, K. A., 467, 1727

McGinnis, E., 1039N

McGuire, B., $1281 \mathrm{~N}$

McKay, A. C., 50

McKirdy, S. J., 770

MCMV. See Maize chlorotic mottle virus

McRoberts, N., 1866N

McTaggart, A. R., 1182N

Meadow, R., 1269N

Medicago sativa (alfalfa)

Aphanomyces euteiches on, mineral seed coating for control of, 614

Cylindrocladium parasiticum on, in China, $890 \mathrm{~N}$

Microdochium tabacinum on, in China, 87

Medina, R., 1732

Meehania urticifolia (nettleleaf meehania), Golovinomyces biocellatus on, in Korea, 892N Mejía, J. F., 994

Mejías, A., 896N, 1190N, 1657N

Mello, A. P. O. A., 423N

Melo, M. P., 1177N

Meloidogyne spp.

M. enterolobii 
on hot pepper, in China, $557 \mathrm{~N}$

on jackfruit, $1284 \mathrm{~N}, 1868 \mathrm{~N}$

M. graminicola, in banana, in China, $420 \mathrm{~N}$

M. hapla, on crofton weed, in China, $1654 \mathrm{~N}$

$M$. incognita, on tomato, grafting rootstocks with resistance to Ralstonia solanacearum, 119

M. javanica, on Tephrosia vogelii, in Brazil, $1285 \mathrm{~N}$

M. mali, on crape myrtle, in Japan, $893 \mathrm{~N}$

M. partityla, on laurel oak, in South Carolina, $1041 \mathrm{~N}$

Melon. See Cucumis spp.

Men, X.-Y., 1856N

Menalled, F., 1383

Menalled, F. D., 1803

Menexes, G., 240

Mercurio, R., 44

Metrosideros polymorpha ('Ōhi`a), Ceratocystis

fimbriata on, in Hawai'i, 1276N

Mexican hens. See Echeveria tolimanensis

Meyer, S. M., 1210

Meza-Moller, A., 729N

Miano, D. W., $1290 \mathrm{~N}$

Miao, C.-P., $1650 \mathrm{~N}$

Miao, P., 890N

Michailides, T. J., 1161, 1185N, 1353

Michel, V. V., $1187 \mathrm{~N}$

Micrococcus luteus, on mango, in India, 1640N

Microdochium tabacinum, on alfalfa, in China, 87

Mijit, M., 422N

Miller, S. A., 163N, 285N, 1035N, 1854N

Miller, Z., 1383

Miller, Z. J., 1803

Millet. See Eleusine coracana; Setaria italica

Milojevic, K., 286N

Milosavljević, A., 724N, 1035N, 1274N, 1645N

Milošević, D., 723N, 736N, 896N, 1277N $1450 \mathrm{~N}, 1869 \mathrm{~N}$

Milosevic, D., 1279N

Miloševic, D., 416N

Minami, S. N., 1642N

Mineral seed coating, for control of

Aphanomyces euteiches on alfalfa

seedlings, 614

Ming, R., 544

Minsavage, G. V., 415N

Minutolo, M., 1655N

Mirabilis jalapa (four o'clock flour), Pseudoidium nyctaginacearum on, in Korea, $728 \mathrm{~N}$

Miranda, J., 1449N

Miravalles, A., 1449N

Mirkov, T. E., $1656 \mathrm{~N}$

Misek, K. W., 1210

Mitrović, J., 1578

Mitrović, M., 551N, 1035N, 1274N, 1645N

Mitsunaga, T., 904

Mizubuti, E. S. G., 1537

Mo, J. Y., 288N

Moens, M., 947

Mohammadi, H., 1181N

Mohankumar, S., $558 \mathrm{~N}, 559 \mathrm{~N}$

Mohd, M. H., 1650N

Mol, F. de, 667

Molhoek, W., 535

Molina, M., $1177 \mathrm{~N}$

Molina-Bravo, R., $1855 \mathrm{~N}$

Mollov, D., 422N, 1038N

Momordica charantia (bitter gourd)

Phoma cucurbitacearum on, in Korea, $727 \mathrm{~N}$

Podosphaera xanthii on, in Taiwan, $726 \mathrm{~N}$

Mondal, K. K., 1268N

Monfort, W. S., 836

Mongolian oak. See Quercus mongolica

Monilinia spp.

M. fructicola

on apple, in Pennsylvania, $1179 \mathrm{~N}$

intraspecific diversity of populations from blossoms and fruit of different hosts in Greece, 1353 on peach, in vitro bioassay for estimating fungicide residues, 1727

on pear, in Italy, $556 \mathrm{~N}$

M. laxa, intraspecific diversity of populations from blossoms and fruit of different hosts in Greece, 1353

on plum, in China, 1775

M. polystroma

on apple, in Croatia, $1181 \mathrm{~N}$

on peach, in Slovenia, $1281 \mathrm{~N}$

on pear, in Italy, $556 \mathrm{~N}$

on stone fruit, in Serbia, 709

Monjero, K., 1870N

Montecchio, L., 1183N

Monterey pine. See Pinus radiata

Montesinos, E., 1816

Montesinos-Herrero, C., 1416

Moon, J. S., 1189N

Moore, M. J., 401, 1841

Moore, P., 939

Moragrega, C., 1816

Moral, J., 58

Moreira, E. N., 1216

Moreira, S. I., $1177 \mathrm{~N}$

Moreira, W. R., 157N

Moreira-Carmona, L., 1855N

Moreno, J., 962

Moreno-Salazar, S. F., 729N

Moricca, S., 1860N

Mosca, S., 44

Moshrefi Zarandi, D., 1186N

Mou, H. F., 417N

Mucor irregularis, on corn, in China, $159 \mathrm{~N}$

Muehlbauer, F. J., 1446N

Mueller, D. S., 347

Mugambi, C., $1870 \mathrm{~N}$

Mukhtar, T., $1870 \mathrm{~N}$

Mulenga, R. M., 1290N

Multiplex PCR

for Colletotrichum spp. on soybean, 1559

for $P$. chrysanthemi on chrysanthemum, 195

for Plasmodiophora brassicae in soil, 1002

for Ralstonia solanacearum, 333

Multiplex real-time PCR

for potyviruses and a pararetrovirus in canna, 1695

for Puccinia horiana and P. chrysanthemi on chrysanthemum, 195

Mulvey, R. L., 893N

Munck, I. A., 1374

Munda, A., $1281 \mathrm{~N}$

Muniz, M. F. B., 1040N

Munkvold, G. P., 1616, 1847

Munyaneza, J. E., 910, 1269N

Murcia, N., 125

Murillo-Williams, A., 418N

Murithi, H., 886N

Murithi, H. M., 420N

Murori, R., 899N

Musa spp. (banana)

Meloidogyne graminicola in, in China, $420 \mathrm{~N}$

Pratylenchus goodeyi on, in China, 731N

Mushroom, needle. See Flammulina velutipes

Muskmelon. See Cucumis melo

Muzhinji, N., 1790

Myclobutanil, for Venturia inaequalis on apple, resistance to, 1526

Mycocentrosporaacerina sp., on peony, in Chile, $284 \mathrm{~N}$

Mycotoxins, Ustilago maydis on corn and, 1236

Myers, K., 659

Myrica rubra (Chinese bayberry, red bayberry), Cladosporium perangustum on, in China, $1283 \mathrm{~N}$

Myrothecium roridum

on hiemalis begonias, in China, $1866 \mathrm{~N}$

on Swedish ivy, in China, 1447N

Myung, I.-S., 1640N

Mzengeza, T., 899N
Nacro, S., 14

Naegele, R. P., 676, 1808, 1832

Nagendra Prasad, M. N., $1868 \mathrm{~N}$

Nagendran, K., 558N, 559N, 1190N

Nahson, J., $1035 \mathrm{~N}$

Naidu, R. A., 293N, 558N, 559N, 1286N

Naik, K. S. S., $1287 \mathrm{~N}$

Nair, P. V. R., 731N

Nakhla, M. K., 1584

Nakkeeran, S., 1190N, 1279N, 1280N

Nam, E. Y., 1648N

Nan, Z., 87

Nandina domestica (heavenly bamboo), cucumber mosaic virus in, $1191 \mathrm{~N}$

Nappo, A. G., $1289 \mathrm{~N}$

Nara, C., $1857 \mathrm{~N}$

Narcissus tazetta (paperwhite), cyrtanthus elatus virus $A$ in, in India, $1658 \mathrm{~N}$

Nautiyal, C. S., $897 \mathrm{~N}, 1189 \mathrm{~N}$

Navas, A., $1449 \mathrm{~N}$

N'chimbi Msolla, S., 899N

Ndikumana, I., 899N

Ndunguru, J., $1290 \mathrm{~N}$

Nectarine, Fusicladium carpophilum on, trifloxystrobin and, 467

Needle mushroom. See Flammulina velutipes

Neher, O., 1296

Nelson, M. E., 632

Nelson, S. C., 1310

Nelson Jr, B. D., 31

Nelumbo nucifera (lotus), dasheen mosaic virus in, in China, 1449N

Neocosmospora vasinfecta, on soybean, in Arkansas, 554N

Neoerysiphe galeopsidis on hensbit deadnettle, in Korea, 1179N on Sideritis perfoliata, in Cyprus, $1867 \mathrm{~N}$

Neofusicoccum spp.

N. mediterraneum, on mango, in Sri Lanka, 1858N

N. parvum

on grape, in France, 1859N

on rhododendron, in China, $1179 \mathrm{~N}$

on Vitis heyneana, in China, $417 \mathrm{~N}$

Nephelium lappaceum (rambutan), Fusarium decemcellulare on, in Puerto Rico, 1187N

Nerine yellow stripe virus (NeYSV), in spider lily, in India, $1655 \mathrm{~N}$

Newberry, E., 1488

Nexticapan-Garcez, A., 1590

Ni, H. F., $1864 \mathrm{~N}$

Ni, S. J., 283N

Nicolli, C. P., 1859N

Nicotiana tabacum (tobacco)

Botryosphaeria dothidea on, in China, 890N brassica yellows virus in, in China, $1192 \mathrm{~N}$

turnip yellows virus in, in China, $1870 \mathrm{~N}$

Nie, X., 1658N

Nightshade. See Solanum americanum; Solanum elaeagnifolium

Nigrospora sphaerica, on tea, in China, $417 \mathrm{~N}$

Nikoli, 896N

Nikolić, D., 894N

Nikolić, Z., 723N, 736N, 1277N, 1450N

Nikolic, D., $286 \mathrm{~N}$

Nikolic, I., 281N

Niu, E. B., $1289 \mathrm{~N}$

Niu, X.-Q., 554N, 1040N

Niu, Y. B., $1289 \mathrm{~N}$

Njau, P., 899N

Nocchi, P. T. R., 1125

Nolte, P., 417N

Nome, C. F., 735N

Nor, N. M. I. M., 1650N

Norman, D. J., 874

Norway pine. See Pinus resinosa

Novoselović, D., 896N

Nunes, W. M. C., 1125

Nunney, L., 1457

Nutter Jr., F. W., 593, 1026, 1247

Nyasani, J. O., 899N 
Oak. See Quercus spp.

Oblinger, B. W., 1041N

Ochoa-Martínez, D. L., 1041N

Ochoa-Meza, A., 729N

O’Donnell, K., 1622

Oelofse, D., 1652N

'Ōhi`a. See Metrosideros polymorpha

Ohta, K., $1445 \mathrm{~N}$

Ohtani, S., 740

Oilseed rape. See Brassica spp.

Ojiambo, P., 80

Ojiambo, P. S., 428

Okada, T., $1857 \mathrm{~N}$

O'Keefe, G., 1738

Okorska, S., 420N

Okorski, A., 420N

Olachea, J. E., 896N

Olaya, G., 544

Olea europea (olive)

Pseudomonas savastanoi pv. savastanoi on, in Japan, 1445N

Spilocaea oleagina, Colletotrichum acutatum, and Pseudocercospora cladosporioides on, evaluation of new cultivars, 58

Verticillium dahliae on, irrigation frequency and, 488

Olivares-García, C., 962

Oliveira, R. R., $1037 \mathrm{~N}$

Oliveira Jr., R. S., 1037N

Oliveira-Hofman, C., 1170

Olson, S. M., 119

Oludare, A., $735 \mathrm{~N}$

Oncidium orchids, Burkholderia gladioli on, in

Brazil, 1642N

Oncimum basilicum (basil)

Cochliobolus lunatus on, in India, 419N

Peronospora belbahrii on in China, 1642N

in Czech Republic, $418 \mathrm{~N}$

Ondrej, V., 418N

O'Neal, E. S., 823, 1070

Onion. See Allium cepa

Onion yellow dwarf virus (OYDV), in shallot, in Serbia, $1450 \mathrm{~N}$

Open alleys, fungicides in corn and, 263

Ophiognomonia clavigignenti-juglandacearum, on butternut

influence of temperature and humidity on conidia viability, 1841

inhibition by Juglans spp. bark extracts, 401

Oppenheim, D., 1048

Orazaly, M., 1140

Orfanidou, C. G., 734N, 894N

Orgaz, F., 488

Oriental chestnut oak. See Quercus acutissima

Oriental plane. See Platanus orientalis

Origanum vulgare (oregano), Phoma multirostrata var. macrospora on, in Italy, $1646 \mathrm{~N}$

Oro, V., 730N

Orobanche spp.

O. cumana (sunflower broomrape), in China, race composition and distribution of, $291 \mathrm{~N}$

O. ramosa

on celery, in Italy, $1188 \mathrm{~N}$, Cover photo: Aug

Ortega, S. F., $1650 \mathrm{~N}$

Ortega-Acosta, S. A., 1041N

Ortiz-Lytle, M. C., 415N

Ortu, G., $159 \mathrm{~N}, 161 \mathrm{~N}, 162 \mathrm{~N}, 729 \mathrm{~N}, 1037 \mathrm{~N}$, $1039 \mathrm{~N}, 1183 \mathrm{~N}, 1448 \mathrm{~N}, 1646 \mathrm{~N}, 1868 \mathrm{~N}$

Oryza sativa (rice)

Burkholderia glumae on, in northern India, $1268 \mathrm{~N}$

Fusarium fujikuroi on, PIRA-PCR for detection of genotypes with carbendazimresistance alleles, 1241

Magnaporthe oryzae on detection using real-time PCR, 219 effects of pyramiding quantitative resistance genes pi21, Pi34, and Pi35 on, 904
Pantoea agglomerans on, in Venezuela, 552N

Pseudomonas fuscovaginae on, in Korea, $1033 \mathrm{~N}$

Pythium arrhenomanes on, in seedlings around Japanese rice fields, 1823

rice orange leaf phytoplasma on, new vector of in south China, 1483, Cover photo: Nov rice stripe necrosis virus in, in Benin, $735 \mathrm{~N}$ rice yellow mottle virus in, in Malawi, $899 \mathrm{~N}$ Xanthomonas oryzae pv. oryzicola on, in Vietnam, $1853 \mathrm{~N}$

Osborne, L., $1176 \mathrm{~N}$

Osterbauer, N. K., 176

Ostry, M. E., 401, 1841

Ouédraogo, S. L., 1854N

Ouedraogo, L., $551 \mathrm{~N}$

Owati, A., 886N

OYDV. See Onion yellow dwarf virus

P. trifoliata $\times C$. sinensis (Carrizo citrange), Washington navel sweet orange grafted on, citrus viroids and, 125

Pájtli, É., 898N, 1288N

Pérez, I., 1282N

Pérez-Artés, E., 780

Pérez-Colmenares, Y., 896N

Pérez-Escolar, G., 1449N

Pérez-Sierra, A., 1857N

Pachysandra terminalis, cucumber mosaic virus in, in United States, $422 \mathrm{~N}$

Padgett, G. B., 1596

Padma, J. G., 1287N

Paeonia spp. (peony), Mycocentrosporaacerina sp. on, in Chile, $284 \mathrm{~N}$

Paetzold, L., 274

Palacios-Cardiel, C., 552N

Palkovics, L., 898N, 1288N

Pallás, V., 899N, $1191 \mathrm{~N}$

Palm, areca. See Areca catechu

Palm, clustering fishtail. See Caryota mitis

Palmateer, A. J., 1279N

Palmero, D., 723N

Palou, L., 1416

Pan, H., 219

Pan, Y. M., 1861N

Panax spp.

$P$. ginseng (Asian ginseng), Ilyonectria robusta on, in China, $156 \mathrm{~N}$

$P$. notoginseng (sanqi)

Fusarium flocciferum on, in Yunnan, 1650N Haematonectria ipomoeae on, in China, 1273N

Pane, A., 1446N

Panmongkol, A., 225

Pantoea spp.

$P$. agglomerans

on onion, in Michigan, 1034N, Cover photo: Jul on red adzuki bean, in China, 1269N on rice, in Venezuela, $552 \mathrm{~N}$

$P$. anthophila, on wampee, in China, $416 \mathrm{~N}$

Papaioannou, I. A., 286N

Papavasileiou, A., 1353

Papaya. See Carica papaya

Paperwhite. See Narcissus tazetta

Pappu, H. R., 899N, 1190N

Parastagonospora nodorum, on wheat, evaluation and association mapping of resistance to, 1333

Pardina, P. Rodríguez, 733N

Paret, M. L., 119, 1488, 1640N

Park, C.-Y., 733N

Park, E.-H., 733N

Park, J. H., 158N, 161N, 727N, 728N, 730N, $731 \mathrm{~N}, 889 \mathrm{~N}, 892 \mathrm{~N}, 1178 \mathrm{~N}, 1179 \mathrm{~N}, 1180 \mathrm{~N}$, $1185 \mathrm{~N}, 1648 \mathrm{~N}, 1653 \mathrm{~N}, 1863 \mathrm{~N}$

Park, M. J., 557N, 728N, 889N, 1178N, 1179N, $1180 \mathrm{~N}, 1273 \mathrm{~N}, 1653 \mathrm{~N}$

Parrella, G., $1289 \mathrm{~N}$

Parsley. See Petroselinum crispum

Parsnip. See Pastinaca sativa
Parthenium hysterophorus, groundnut bud necrosis virus in, $1287 \mathrm{~N}$

Pasche, J., 1254

Pasche, J. S., 474

Paspalum vaginatum, Gaeumannomyces graminis on, in China, $1858 \mathrm{~N}$

Pasqualini, A., $1289 \mathrm{~N}$

Pastinaca sativa (parsnip), Pseudomonas syringae pv. coriandricola on, in Serbia, $416 \mathrm{~N}$

Patel, J. S., 1184N

Patel, P. P., 1640N

Patil, V. B., 1274N

Patocchi, A., 370

Paul, C., 1059

Paul, P. A., 1216, 1434

Paula Júnior, T. J., 1098, 1537

Paulitz, T., $1188 \mathrm{~N}$

Paulitz, T. C., 604, 648, 1280N

Paulownia spp., Verticillium dahliae on symptomless host and nonhost responses, 962

Pavlovic, S., 283N, 1279N

Payton, M., 188

Pazdernik, K. T., 1247

PCR (polymerase chain reaction). See also

Multiplex PCR; Real-time PCR

for Botrytis spp. on broad bean, 691

for detection of genotypes with carbendazim-resistance alleles in Fusarium fujikuroi on rice, 1241

for detection of Plasmodiophora brassicae in soil, 1002

for Stenocarpella macrospora and Stenocarpella maydis on corn, 761

Pea. See Pisum sativum

Peach

Alternaria alternata on

fitness and competitive ability of isolates with fungicide resistance, 1744

SDHI fungicide resistance and, 65

Colletotrichum spp. on

C. siamense, resistant to thiophanate-methyl and azoxystrobin, 806

C. gloeosporioides, in South Carolina, 797

Fusicladium carpophilum on, trifloxystrobin and, 467

Monilinia spp. on

M. fructicola on peach, in vitro bioassay for estimating fungicide residues, 1727

M. polystroma, in Slovenia, $1281 \mathrm{~N}$

peach latent mosaic viroid in, in Mexico, 899N

Peach latent mosaic viroid (PLMVd), in peach, in Mexico, 899N

Peanut. See Arachis hypogaea

Pear. See Pyrus communis

Pearce, T. L., 1227

Pearson, H. G., 1863N

Pecan. See Carya illinoinensis

Pectobacterium carotovorum subsp. brasiliense on potato, in Switzerland, 551N on potato and other vegetables, in Poland, 1271N on Seleng wormwood, in China, $1175 \mathrm{~N}$

Pedrozo, R., 1865N

Peever, T. L., 1446N

Pegg, G. S., 71

Pei, D. L., $1862 \mathrm{~N}$

Pei, W. H., 890N

Pelargonium flower break virus (PFBV), in Pelargonium spp., $735 \mathrm{~N}$

Peng, B., $1291 \mathrm{~N}$

Peng, D., 731N

Peng, D. L., 1868N

Peng, J., 898N, 1190N

Peng, X. D., 159N, 160N

Peng, Y., 159N

Penicillium spp.

$P$. expansum

on apple (stored), isolates with reduced sensitivity to fludioxonil, $1182 \mathrm{~N}$ 
on kiwifruit (stored), in China, 1037N

on citrus, pathogenicity and host susceptibility, 21

$P$. digitatum, on citrus in California, fludioxonil resistance in, $1447 \mathrm{~N}$

Pensa, P., 161N, 1039N, 1448N, 1868N

Peony. See Paeonia spp.

Pepper. See Capsicum spp.

Pepper mild mottle virus (PMMoV), in peppers, in Oklahoma, 736N

Pepper vein yellows virus (PeVYV)

in pepper

in China, $1288 \mathrm{~N}$

in United States, $1656 \mathrm{~N}$

in red pepper, in mainland China, $1190 \mathrm{~N}$

Pepper yellow vein Mali virus (PeYVMLV), in tomato, in Burkina Faso, $732 \mathrm{~N}$

Peptide, synthetic, for control of Stemphylium vesicarium on pear, 1816

Pereira, O. L., 157N, 555N, 1036N, 1177N

Perelló, A., $1177 \mathrm{~N}$

Peres, N. A., 954

Perez, C. A., 554N

Perez-Brito, D., 1590

Perez-Cuevas, M., 1187N

Perez-Rodríguez, M., 488

Peronospora spp.

$P$. belbahrii on basil, in China, $1642 \mathrm{~N}$ on sweet basil, in Czech Republic, 418N

$P$. cf. ducometi, on buckwheat, in Czech Republic, $1178 \mathrm{~N}$

Persea americana (avocado), Colletotrichum godetiae on, in Mexico, $555 \mathrm{~N}$

Persian buttercup. See Ranunculus asiaticus

Persian speedwell. See Veronica persica

Persimmon. See Diospyros kaki

Pestalotiopsis spp.

$P$. adusta

on coconut, in Brazil, 1036N on Dictyosperma album, in China, 1040N

P. menezesiana, on coconut, in China, $554 \mathrm{~N}$

P. microspora, on pecan, in China, $1276 \mathrm{~N}$

Peter, K. A., 1179N

Pethybridge, S. J., 1227, 1310

Petroselinum crispum (parsley), Pseudomonas syringae pv. coriandricola on, in Serbia, $416 \mathrm{~N}$

Petrović, G., 736N

Petrović, K., 1186N, 1647N

Petrželová, I., 418N, 892N, 1178N

Peucedanum japonicum, Erysiphe heraclei on, in Korea, $161 \mathrm{~N}$

PeVYV. See Pepper vein yellows virus

PeYVMLV. See Pepper yellow vein Mali virus

PFBV. See Pelargonium flower break virus

Phakopsora pachyrhizi, on soybean

archaeophytopathology of, 575

comparison of pathogenicity among isolates and identification of resistant soybean genotypes, 1059

in Costa Rica, $418 \mathrm{~N}$

in Malaysia, $420 \mathrm{~N}$

temporal dynamics associated with leaf area index with cultivars of different maturity groups, 1216

Pham, Q. T., 225

Phan, C. K., 419N

Phaseolus vulgaris (bean)

'Candidatus Phytoplasma solani on, in Serbia, $551 \mathrm{~N}$

Curtobacterium flaccumfaciens pv.

flaccumfaciens on, 1665

Pythium spp. on

effect of timing and duration of soil saturation, 112

$P$. aphanidermatum on, in Oman, 419N

rhynchosia yellow mosaic virus in, in India, $1291 \mathrm{~N}$

Sclerotinia sclerotiorum on adaptation and common sources of resistance to, 1098

fungicide sensitivity of, 1537

Sclerotium rolfsii on, in India, $1280 \mathrm{~N}$

Phelan, J., 558N

Phellinidium qilianense, on Qilian juniper, in

Northwest China, 39

Phenylpropanoid pathway, resistance of mango against Ceratocystis fimbriata and, 447

Phialophora gregata, on soybean, in South Dakota, $1176 \mathrm{~N}$

Phillips, N. A., 1236

Phlox paniculata, Choanephora cucurbitarum on, in Korea, $1180 \mathrm{~N}$

Phoenix reclinata (wild or Senegal date palm),

Fusarium oxysporum f. sp. canariensis on, in

Florida, $887 \mathrm{~N}$

Phoma spp.

P. cucurbitacearum, on bitter gourd, in Korea, $727 \mathrm{~N}$

P. koolunga, on field pea, relative host resistance determination by individual pathogens, 580

P. multirostrata var. macrospora, on oregano, in Italy, $1646 \mathrm{~N}$

$P$. pinodella, on field pea, relative host resistance determination by individual pathogens, 580

$P$. sorghina var. saccharum, on sugarcane, in China, 325

Phomopsis spp.

P. longicolla, $290 \mathrm{~N}, 1517$

on pear, biological and molecular characterization of, 1704

Physalis spp.

P. alkekengi (Chinese lantern), Colombian datura virus in, $898 \mathrm{~N}$

P. pubescens (husk tomato), Pseudoidium cf. neolycopersici on, in China, $1862 \mathrm{~N}$

Physarum cinereum, on lettuce, rocket, endive, chicory, and celery, in Italy, $1272 \mathrm{~N}$

Phytophthora spp.

on asparagus, in Japan, $1857 \mathrm{~N}$

P. cactorum, on Ribes lobbii, in Oregon, $157 \mathrm{~N}$

P. capsici

on Brassica spp., pathogenicity of, 1721

on greenhouse ornamentals, 1808

P. cinnamomi, on proteas, in Turkey, $1181 \mathrm{~N}$

P. citrophthora, on Ribes lobbii, in Oregon, $157 \mathrm{~N}$

on citrus, potassium phosphite and heat

treatments for management of, 1477

P. colocasiae, on taro, in Turkey, $1445 \mathrm{~N}$

P. cryptoea, on common sage, in Italy, $161 \mathrm{~N}$

$P$. infestans

on potato: clonal lineage US-23, in Idaho, $417 \mathrm{~N}$; fungicide sensitivity of U.S. genotypes to six oomycete-targeted compounds, 659; rain forecasts for scheduling management tactics, 683

on tomato: detached-leaflet evaluation for resistance to, 718; fungicides for control of US-22, US-23, and US-24 Isolates, 641

$P$. kernoviae, difference in virulence and sporulation of isolates from two different geographic regions, 460

P. lateralis, on Port Oxford cedar, pathogenicity of lineages on different selections, 1133

P. macilentosa, P. mississippiae, and $P$. stricta, recovered from irrigation reservoirs in mississippi and alabama nurseries, 1390

P. megasperma, on Celtis australis, in Italy, $155 \mathrm{~N}$

$P$. mississippiae, recovered from irrigation reservoirs in mississippi and alabama nurseries, 1390

P. nicotianae

on cherry, in China, 284N

on Konjac, in China, $283 \mathrm{~N}$

on potato, etiology of, 474
P. niederhauserii

on almond, in California, $1863 \mathrm{~N}$

on Begonia elatior, in France, 1277N

$P$. occultans, on ceanothus, boxwood, rhododendron, and other hosts in horticultural nurseries in oregon, $1282 \mathrm{~N}$

P. pachypleura, on Aucuba japonica, in Italy, $1860 \mathrm{~N}$

P. palmivora, on pistachio, in Turkey, $1866 \mathrm{~N}$

$P$. pinifolia, bioassay conditions for infection of Pinus radiata seedlings with, 1204

P. pluvialis, on Douglas fir, in Oregon and New Zealand, 727N

recovered from irrigation reservoirs in mississippi and alabama nurseries, 1390

on rhododendron, diversity of foliar species in Oregon nurseries, 1326

P. sojae, on soybean, in China, $1861 \mathrm{~N}$

$P$. stricta, recovered from irrigation reservoirs in mississippi and alabama nurseries, 1390

P. tropicalis, on greenhouse ornamentals, 1808

Phytoplasma disease

of areca palm, in Sri Lanka, 1642N

p. 16 SrII-A

on chrysanthemum, in India, $1641 \mathrm{~N}$ on lilac, $886 \mathrm{~N}$

p. 16 SrII-C

on soybean, in Taiwan, $886 \mathrm{~N}$

on tomato, in Tanzania, 1854N

p. 16SrII-D, on Andrographis paniculata

(Kalmeagh), in India, 155N

Phytopythium helicoides, on kiwifruit, $725 \mathrm{~N}$

Piao, Z., 1277N

Picea engelmanii (Engelmann spruce)

Arceuthobium abietinum on, in Oregon,

$1041 \mathrm{~N}$, Cover photo: Jul

Picot, A., 1161

Pierson, E., 910

Pilkington, S. J., 1227

Pilson, D., 1616

Pina, J. A., 125

Pinel-Galzi, A., 735N

Pinho, D. B., $157 \mathrm{~N}$

Pinnaka, A. K., $725 \mathrm{~N}$

Pinus spp. (pine)

P. nigra (black pine), Trichoderma viride on, in Italy, 44

$P$. radiata (Monterey pine)

bioassay conditions for infection of seedlings with Phytophthora pinifolia, 1204

Bursaphelenchus xylophilus on, in Spain, 1449N

Thyronectria pinicola on, in Australia, 1182N

P. resinosa (red/Norway pine), Heterobasidion annosum on, in Minnesota, 1038N

$P$. rigida (pitch pine)

Bursaphelenchus yongensis on, in Korea, $162 \mathrm{~N}$, Cover photo: Jan

P. strobus (white pine), Cronartium ribicola on, impact on resistant cultivated Ribes and neighboring Eastern white pine in New Hampshire, 1374

Piper betel (betel vine), Canna yellow mottle virus in, in India, 1189N

PIRA-PCR, for detection of genotypes with carbendazim-resistance alleles in Fusarium fujikuroi on rice, 1241

Pirc, M., 415N

Pistachio. See Pistacia vera

Pistacia spp.

P. vera (pistachio) Phytophthora palmivora on, in Turkey, $1866 \mathrm{~N}$ Rhodococcus sp. on, in California and Arizona, 1468

$P$. atlantica $\times P$. integerrima, Rhodococcus spp. on, in New Mexico, 1854N

Pisum sativum (pea)

Aphanomyces euteiches on, in Alberta, Canada, 288N

Ascochyta spp. on, sensitivity to boscalid, fluxapyroxad, and prothioconazole, 1254 
Didymella pinodes, Phoma pinodella, and $P$. koolunga on, relative host resistance determination by individual pathogens, 580

Pseudomonas syringae pv. syringae on, in Serbia, $724 \mathrm{~N}$

Rhizoctonia spp. on, in Oregon and Washington, characterization and pathogenicity of, 604

Pitch pine. See Pinus rigida

Pivic, R., 283N

Pizarro, L., 891N

Plantago asiatica mosaic virus (PlAMV)

in hybrid lilies, in United States, 292N in lily

in Hungary, 1288N

in Italy, $1289 \mathrm{~N}$

Plasmodiophora brassicae

on Brassica spp., resistance in genotypes from China, 776

in soil, multiplex qPCR assay for detection and quantification of, 1002

on winter oilseed rape, risk potential of, 667

Plasmopara spp.

P. halstedii

on black-eyed Susan, in United States, 1278N on purple velvet plant, in Florida, 1279N

P. obducens, on impatiens, in North Dakota, $1039 \mathrm{~N}$

Platanus spp.

P. $\times$ acerifolia (London planetree), Erysiphe platani on

in Brazil, $157 \mathrm{~N}$

in Greece, $286 \mathrm{~N}$

P. occidentalis (American sycamore), Erysiphe platani on, in Greece, $286 \mathrm{~N}$

P. orientalis (oriental planes), Erysiphe platani on, in Greece, $286 \mathrm{~N}$

Platycodon grandiflorus (balloon flower),

Fusarium armeniacum on, in China, 1644N

Plectosphaerella cucumerina, on sunflower, in China, 1646N

Plectosporium tabacinum, on pumpkin and squash, in North Carolina, 724N

Plectranthus verticillatus (Swedish ivy),

Myrothecium roridum on, in China, $1447 \mathrm{~N}$

PLMVd. See Peach latent mosaic viroid

Plum, Japanese. See Prunus salicina

Plum pox virus (PPV), in Prunus spp.

evaluation of sampling and testing efficiences of eradication programs in Pennsylvania and Ontario, 1247

impact of eradication programs on, 593

Rec strain, in France, 421N

Pm2 gene, resistance against Blumeria graminis

f. sp. tritici on wheat and, 1118

PMMoV. See Pepper mild mottle virus

PMTV. See Potato mop-top virus

Podosphaera spp.

$P$. cf. erodii, on whitestem filaree, in California, $1866 \mathrm{~N}$

P. fusca, on Potentilla supina, in China, $1862 \mathrm{~N}$

$P$. macularis, on hop, critical period for management of, 632

P. tridactyla

on Prunus hypoleuca, in China, 289N

on sweet cherry, in Korea, $1648 \mathrm{~N}$

P. xanthii

on eggplant, in China, $1856 \mathrm{~N}$

on Gynostemma pentaphyllum, in Korea, 1273N

on Luffa cylindrica, in Korea, $1861 \mathrm{~N}$

on oriental pickling melon, in Korea, $730 \mathrm{~N}$

on torenia, in Korea, $1863 \mathrm{~N}$

on wild bitter gourd, in Taiwan, $726 \mathrm{~N}$

Poghosyan, A., 552N

Poinsettia. See Euphorbia pulchrimma

Polashock, J., 421N

Poletto, T., 1040N

Polston, J. E., 557N

Pomegranate. See Punica granatum

Pomelo. See Citrus maxima
Pontif, M. J., 1633

Poole, G. H., 926

Poornachandra Rao, K., 1868N

Popović, T., 281N, 416N, 723N, 724N, 730N, $886 \mathrm{~N}, 1033 \mathrm{~N}, 1035 \mathrm{~N}, 1274 \mathrm{~N}, 1277 \mathrm{~N}$

Port Oxford cedar. See Chamaecyparis lawsoniana

Porter, L. D., 604

Portier, P., 551N

Pospišil, M., 1656N

Potassium phosphite

for management of Phytophthora spp. on citrus, in combinatation with heat treatment, 1477

resistance of mango against Ceratocystis fimbriata and, 447

Potato. See Solanum tuberosum

Potato mop top virus (PMTV), in potato

in Colorado and New Mexico, 164N cultivar sensitivity, 788

Potato spindle tuber viroid (PSTVd), stability on common surfaces and inactivation with disinfectants, 770

Potato virus $Y$ (PVY), in potato, contact transmission, stability, inactivation, and infection sources, 387

Potentilla supina, Podosphaera fusca on, in China, $1862 \mathrm{~N}$

Potnis, N., 415N, 874

Pouzoulet, J., $1185 \mathrm{~N}$

Powell, C. A., 325

PPV. See Plum pox virus

Prasanna, B. M., 1870N

Pratylenchus spp.

P. goodeyi, on banana, in China, $731 \mathrm{~N}$

$P$. penetrans, on red raspberry, impact on establishment, 939

Prendeville, H. R., 1616

Price III, P. P., 1596

Procków, J., 281N

Procymidone, for Sclerotinia sclerotiorum on bean, assessment of sensitivity of, 1537

Prophage genes, real-time PCR for detection of Spiroplasma citri on citrus and, 149

Proteas. See Leucadendron spp.

Prothioconazole, for Ascochyta spp. on pea, lentil, and chickpea, 1254

Pruning shears, detection of grapevine fungal trunk pathogens on and evaluation of their potential for spread of infection, 976

Prunus spp.

P. armeniaca (apricot), Botryosphaeria obtusa on, in China, $888 \mathrm{~N}$

$P$. avium (sweet cherry)

little cherry virus 1 in, in China, $1191 \mathrm{~N}$

Podosphaera tridactyla on, in Korea, 1648N

P. dulcis (almond)

community structure of Aspergillus flavus and $A$. parasiticus in areas producing in California, 1161

Dothiorella iberica on, in California, $1185 \mathrm{~N}$

Phytophthora niederhauserii on, in California, $1863 \mathrm{~N}$

P. hypoleuca, Podoshaera tridactyla on, in China, 289N

Monilinia spp. on, in Serbia, 709

plum pox virus in

evaluation of sampling and testing efficiences of eradication programs in Pennsylvania and Ontario, 1247

impact of eradication programs on, 593

$P$. salicifolia (capulin cherry), Tranzschelia mexicana on, in United States, evaluation of sampling and testing efficiencies of eradication programs in Pennsylvania and Ontario

P. salicina (plum)

Botrytis cinerea on, in Chile, $888 \mathrm{~N}$

Monilinia spp. on, in China, 1775

Pruvost, O., 1854N

Przetakiewicz, J., 285N
Pseudocercospora spp.

P. atromarginalis, on American nightshade, in Korea, 727N

P. cladosporioides, on olive, susceptibility of new cultivars, 58

$P$. fuligena on tomato, in Ohio, 285N, Cover photo: Feb

Pseudoidium spp.

P. neolycopersici

on croton, in China, $288 \mathrm{~N}$

on husk tomato, in China, $1862 \mathrm{~N}$

P. nyctaginacearum, on four o'clock flour $728 \mathrm{~N}$

Pseudomonas spp.

P. cannabina pv. alisalensis on arugula, in Minnesota, $415 \mathrm{~N}$, Cover photo: Mar

P. cichorii, on tomato, in Tanzania, $1035 \mathrm{~N}$

P. fuscovaginae, on rice, in Korea, $1033 \mathrm{~N}$

P. savastanoi

on Mandevilla sanderi, in Slovenia, $415 \mathrm{~N}$

on olive, in Japan, $1445 \mathrm{~N}$

$P$. syringae pv. actinidiae, on kiwifruit, in Greece, $723 \mathrm{~N}$

P. syringae pv. aptata, on sugar beet, in Serbia, $281 \mathrm{~N}$

$P$. syringae pv. coriandricola, on carrot, parsley, and parsnip, in Serbia, $416 \mathrm{~N}$

P. syringae $\mathrm{pv}$. syringae on apple, in Korea, 1641N on chard, in Serbia, $723 \mathrm{~N}$ on pea, in Serbia, $724 \mathrm{~N}$

$P$. syringae pv. tomato, on tomato, genomeassisted development of diagnostic protocol for detecting high virulence strains, 527

P. viridiflava

on Saposhnikovia divaricata, in China, $281 \mathrm{~N}$ on tomato: in Serbia, 1033N; in Spain, 1270N

Pseudoperonospora spp.

P. cubensis

on buffalo gourd, in North Carolina, 1861N on cucurbits, in Michigan, 676 resurgence of in United States, 428, Cover photo: Apr

$P$. humuli, on hop, pre- and post-infection activity of fungicides for control of, 858

Pseudotsuga menziesii (Douglas fir),

Phytophthora pluvialis on, in Oregon and

New Zealand, $727 \mathrm{~N}$

Pseudozyma aphidis, resistance against

Clavibacter michiganensis on tomato and, 621

Pszczólkowska, A., 420N

$\mathrm{Pu}$, J.-J., 288N

$\mathrm{Pu}$, Z. X., $1283 \mathrm{~N}$

Puccinia spp.

$P$. chrysanthemi, on chrysanthemum, multiplex real-time PCR assay for, 195

$P$. graminis f. sp. tritici on barberry: in U.S. Pacific northwest, 1507; wheat stem rust and, 1113 on wheat, resistance to $\mathrm{Ug} 99$ race group in hybrid derivatives, 1317

$P$. helianthi, on sunflower effect of fungicide and timing of application on management of, 1210

phenotypic diversity in U.S. in 2011-2012, 1604

P. horiana

on chrysanthemum: in India, 1279N; morphology of from naturally infected plants, 1738; multiplex real-time PCR assay for, 195

$P$. lagenophorae, on marigold, in Czech Republic, $892 \mathrm{~N}$

P. linkii, on highbush cranberry, in Alaska, $893 \mathrm{~N}$

P. melanocephala, on sugarcane, screening for resistance with controlled-conditions inoculation, 1633

P. psidii, on Eucalyptus spp. in Australia, $161 \mathrm{~N}$ screening for host resistance, 71 
P. striiformis f. sp. tritici

on barberry, inability to be alternate host in U. S. Pacific northwest, 1500, 1507,

Cover photo: Nov

on wheat: emerging Yr26-virulent races in China, 754; genetic analysis of resistance to, 1153; Yr60 gene and resistance, 508

P. triticina

on durum wheat, in Great Plains region, $156 \mathrm{~N}$ on wheat: genetic analysis of resistance to,

1153; physiologic specialization in U.S. in 2013,1261

Puckett, R. D., 1161

Puig, M., 1816

Pumpkin. See Cucurbita pepo

Punica granatum (pomegranate)

Alternaria alternata on

disease etiology of, 496

in Italy, $1446 \mathrm{~N}$

Ceratocystis fimbriata on, in China, relationship to populations on Eucalyptus in Brazil, 106

Purnamasari, M., 1544

Purple loosestrife. See Lythrum salicaria

Purple velvet plant. See Gynura aurantiaca

Purvis, M. A., 1596

Pyraclostrobin

baseline sensitivity and toxicity of to Sclerotinia sclerotiorum, 267

for Didymella bryoniae on watermelon and muskmelon, resistance against multiple fungicides and, 815

Pyrenophora spp.

$P$. teres f. maculata, on barley, in Idaho, $1860 \mathrm{~N}$

$P$. tritici-repentis, on wheat, evaluation and association mapping of resistance to, 1333

Pyrethrum. See Tanacetum cinerariifolium

Pyrus spp. (pear)

P. bretschneideri, Glomerella cingulata on, in China, $553 \mathrm{~N}$

P. communis

Erwinia amylovora on: 30 years of management in Israel, 1048; in Finland, $1033 \mathrm{~N}$

Monilinia fructicola and $M$. polystroma on, in Italy, $556 \mathrm{~N}$

Phomopsis spp. on, biological and molecular characterization of, 1704

Erwinia amylovora on, evaluation of dormantstage inoculum sanitation for management of, 1147

Stemphylium vesicarium on, synthetic antimicrobial peptide for control of, 1816

Pythium spp.

P. aphanidermatum

on bean, in Oman, $419 \mathrm{~N}$ on spinach, in Italy, $159 \mathrm{~N}$

$P$. arrhenomanes, on rice, in seedlings around Japanese rice fields, 1823

$P$. irregulare, on lamb's lettuce, in Italy, $1650 \mathrm{~N}$

$P$. sulcatum, on fennel, in California, $1645 \mathrm{~N}$

on common bean, effect of timing and duration of soil saturation, 112

on floriculture crops in North Carolina, mefenoxam sensitivity, aggressiveness, and identification of species causing disease, 1550 on soybean, in North Dakota, 31

Qi, Q. Q., 1276N

Qi, X., 1651N

Qiao, G. H., 1657N

Qiao, Q., 1042N

Qiao, X.-G., 1650N

Qilian juniper. See Sabina przewalskii

Qin, H. Y., 1037N, 1644N

Qin, L., 1176N

Qin, L. L., 417N

Qin, P.-W., 1184N

Qin, W.-Q., 554N, 1038N, 1040N
Qin, Y.-H., 1042N

QoI fungicides

for Alternaria alternata on peach, fitness and competitive ability of isolates with resistance to, 1744

for Cercospora sojina on soybean, resistance and, 544, 1347

Qu, B., $1285 \mathrm{~N}$

Qu, H.-Y., 1866N

Qu, S. P., 1179N

Quan, J. Z., 1856N

Quaren, R., 421N

Que, Y. X., 325

Quercus spp. (oak)

Q. acutissima (oriental chestnut oak), Erysiphe alphitoides on, in China, 889N

Q. laurifolia (laurel oak), Meloidogyne partityla on, in South Carolina, 1041N

Q. mongolica (Mongolian oak), Tubakia seoraksanensis on, in China, $891 \mathrm{~N}$

Q. serrata (Japanese oak), Raffaelea quercivora on, sapwood discoloration and, 225

Quesada-Ocampo, L., 428

Quesada-Ocampo, L. M., 724N, 1832, 1861N

Radicchio. See Cichorium intybus

Radish, white. See Raphanus sativus

Raes, J. J., 1526

Raffaelea quercivora, on Japanese oak, sapwood discoloration and, 225

Ragazzi, A., 1860N

Rahman, M., 80

Raimondo, M. L., 1678

Raj, R., $1655 \mathrm{~N}, 1658 \mathrm{~N}$

Raj, S. K., 627, 897N, 1189N, 1655N, 1658N

Rajakaruna, P., 188

Rajeshkumar, P., 1280N

Rajković, D., $1186 \mathrm{~N}$

Rakhashiya, P. M., 1640N

Rallo, L., 58

Ralstonia solanacearum

on chard, in Taiwan, $282 \mathrm{~N}$

on ghoma, in Benin, 1640N

grafting rootstocks with resistance to, for

Meloidogyne incognita on tomato, 119

multiplex PCR assay to detect and

differentiate strains, 333

race I biovar I, on eggplant, in India, 1271N

Ramírez-Trujillo, J. A., 555N

Rambutan. See Nephelium lappaceum

Ramon, M. L., 1645N

Ramos, S. O., 554N

Rampion bellflower. See Campanula rapunculoides

Ramularia veronicae, on Persian speedwell, in Korea, $1178 \mathrm{~N}$

Rana, G. L., 1272N

Randall, J. J., 1468, 1854N

Ranunculus asiaticus (Persian buttercup)

Sclerotinia sclerotiorum on, in Korea, 1653N, Cover photo: Nov

Rao, G. P., $1176 \mathrm{~N}$

Rape. See Brassica napus

Raphanus sativus (white radish), Streptomyces acidiscabies on, in China, $1035 \mathrm{~N}$

Rashed, A., 274

Rashid, K. Y., 160N

Rasmussen, N. M., 1034N

Raspberry, red. See Rubus idaeus

Rater accuracy, disease severity estimates and, 1104

Rathmore, S., 1291N

Ravnikar, M., 415N

RCV-1. See Rose cryptic virus 1

Real-time PCR. See also Multiplex real-time PCR for Anguina spp., 1584

for Colletotrichum spp. on soybean, 1559

for Magnaporthe oryzae on rice, 219

for potyviruses and a pararetrovirus in canna, 1695 for prophage genes of Spiroplasma citri on citrus, 149

for Sphacelotheca reiliana on maize, 1847

for Stenocarpella macrospora and

Stenocarpella maydis on corn, 761

for Verticillium dahliae on woody hosts, 866

Rearick, E., 1296

Red bayberry. See Myrica rubra

Red pepper. See Capsicum frutescens

Red pine. See Pinus resinosa

Red raspberry. See Rubus idaeus

Red table beet. See Beta vulgaris subsp. vulgaris cv. Boro

Redbud. See Cercis canadensis

Reddy, D. L., 1287N

Reddy, P. N., 1784

Reeser, P., 727N, 1133

Reeser, P. W., $1282 \mathrm{~N}$

Regassa, B., 1870N

Reinhardt, R., 1578

Reinsel, M. D., 292N

Ren, J., $1275 \mathrm{~N}$

Ren, R., 442

Renedo, F., 1449N

Renteria-Martinez, M. E., 729N

Renukadevi, P., 1190N, 1279N

Requena, J., 962

Resende, R. O., 1869N

Resistance. See also Host resistance

of Alternaria alternata on peach fitness and competitive ability of field isolates, 1744

against SDHI fungicides, 65

of Botrytis cinerea

on grape, isolation of boscalid resistant isolates carrying the mutations $\mathrm{H} 272 \mathrm{R}$, H272Y, P225L, and P225H, 891N

on tomato and strawberry, 240

against carbendazim, PIRA-PCR for detection of genotypes with resistance alleles in Fusarium fujikuroi on rice, 1241

of Cercospora spp.

C. beticola, on sugar beet, PCR-RFLP analysis to monitor, 355

C. kikuchii, on soybean, 1596

C. sojina, on soybean, against QoI fungicides, 544, 1347

of Colletotrichum truncatum against thiabendazole, 1590

of Didymella bryoniae, against multiple fungicides, 815

against fludioxonil, in Penicillium digitatum on citrus in California, $1447 \mathrm{~N}$

of Fusarium asiaticum against carbendazim, in China, 342

identifying and analyzing the diversity of resistance gene analogs in Rubus spp., 994

against myclobutanil resistance and difenoconazole, in Venturia inaequalis on apple, 1526

against QOI fungicides, Cercospora sojina on soybean and, 544, 1347

of soybean against glyphosate, sudden death syndrome and, 347

of Venturia inaequalis on apple, effect of delayed-dormant chemical treatments on demethylation inhibitor sensitivity, 1751

Reynolds, G., 415N

Rezende, J. A. M., 165N, 423N

Rhamphicarpa fistulosa, on peanut, soybean, and tossa jute, in Togo, 1654N

Rhizoctonia spp.

$R$. AG-U, on azalea, weather-based forecasting of develelopment of in container-grown plants, 100 associated with rooibos, compost as soil amendment for disease suppression and, 1020 binucleate (BNR)

on azalea, spread from nursery propagation floors to trays containing stem cuttings, 842 
on potato: anastomosis groups and pathogenicity, 1790; new anastamosis group of, 1757

evaluation of methods to quantify populations in soil, 836

on onion, in Oregon and Washington, 648

on pea, in Oregon and Washington,

characterization and pathogenicity of, 604

R. solani

AG 1-IB: on Begonia semperflorens, in China, $1652 \mathrm{~N}$; on bonnet bellflower, in China, $1182 \mathrm{~N}$; on butterfly lavender, in Italy, 1039N; on creeping bellflower, in Italy, $1037 \mathrm{~N}$; on rose campion, in Italy, $162 \mathrm{~N}$, Cover photo: Jan

AG4-HG-I: on Impatiens walleriana, in China, $1653 \mathrm{~N}$; on sugar beet, in China, $1185 \mathrm{~N}$

AG4-HG-III, on buckwheat, in China, 1187N

on potato, anastomosis groups and pathogenicity, 1790

on rice, Brassica cover crop with host resistance and azoxystrobin for management of, 883

Rhizopus spp.

$R$. arrhizus, on peanut, in China, $1448 \mathrm{~N}$

$R$. stolonifer, on sweetpotato, relationships of preharvest weather conditions and soil factors to susceptibility, 848

Rhodococcus spp., on pistachio

in California and Arizona, 1468

in New Mexico, 1854N

Rhododendron spp.

Neofusicoccum parvum on, in China, 1179N

Phytophthora spp. on

diversity of foliar species in Oregon nurseries, 1326

P. occultans, in Oregon, $1282 \mathrm{~N}$

Rhizoctonia spp. on

$R$. AG-U, weather-based forecasting of develelopment of in container-grown plants, 100

$R$. binucleate sp., spread from nursery propagation floors to trays containing stem cuttings, 842

Rhynchosia yellow mosaic virus (RhYMV), in bean, in India, 1291N

Ribes spp.

Cronartium ribicola on, impact on resistant cultivated Ribes and neighboring Eastern white pine in New Hampshire, 1374

Phytophthora cactorum and P. citrophthora on, in Oregon, $157 \mathrm{~N}$

Riccioni, L., $1186 \mathrm{~N}$

Rice. See Oryza sativa

Rice orange leaf phytoplasma (ROLP)

on rice, new vector of in south China, 1483 Cover photo: Nov

Rice stripe necrosis virus (RSVN), in rice, in Benin, $735 \mathrm{~N}$

Rice yellow mottle virus (RYMV), in rice, in Malawi, $899 \mathrm{~N}$

Rich, J. R., 119

Ridge gourd. See Luffa acutangula

Rindi, F., 740

Rios, J. A., 157N

Rios, V. S., 447

Ristaino, J. B., 659

Ristic, D., $1279 \mathrm{~N}$

Ritchie, L., 119

Rivera, Y., 1278N

Rivera-Vargas, L. I., $1187 \mathrm{~N}$

Robak, J., 729N

Robertson, A. E., 1026

Robertson, C. L., 1596

Robertson, L., 1449N

Robin, C., 1133

Roca, L. F., 58

Rocket, wild. See Diplotaxis tenuifolia

Rocket endive. See Eruca sativa

Rockey, W., 874

Rodoni, B. C., 770
Rodríguez, V., 1449N

Rodríguez-León, F., $1175 \mathrm{~N}$

Rodríguez-Román, E., 896N, 1190N

Rodrigues, F. A., 157N, 447, 1216

Rodriguez-Salamanca, L. M., 1832

Roe, N., 1450N

Roh, K., 588

Rojas, E. S., 564

Rollan, C., 1732

ROLP. See Rice orange leaf phytoplasma

Rolshausen, P. E., $1185 \mathrm{~N}$

Román, A., 891N

Romano, M., 1190N, 1657N

Romero, M. P., 761

Romo-Tamayo, F., 729N

Ronco, B. L., 1732

Rooibos. See Aspalathus linearis

Rosa spp., rose cryptic virus 1 in, in Canada, $558 \mathrm{~N}$

Rosado, A. W. C., 1036N

Rose campion. See Lychnis coronaria

Rose cryptic virus 1 (RCV-1), in Rosa spp., in Canada, $558 \mathrm{~N}$

Roselle. See Hibiscus sabdariffa

Rosenzweig, N., 355

Rothrock, C. S., 836

Rott, M., 558N

Rouse, M. N., 1317

Rowhani, A., 895N

Rowlandson, T., 310

Roy, R. K., 897N, 1658N

RSVN. See Rice stripe necrosis virus

Ruan, L., 731N

Rubber trees. See Hevea brasiliensis

Rubio, L., 895N

Rubus spp.

$R$. idaeus (red raspberry), Pratylenchus penetrans on, impact on establishment, 939

identifying and analyzing the diversity of resistance gene analogs in, 994

$R$. phoenicolasius (wineberry) Sphaerulina tirolensis on, in United States, $1275 N$, Cover photo: Sep

Rudbeckia fulgida (black-eyed Susan), Plasmopara halstedii on, in United States, $1278 \mathrm{~N}$

Ruhl, G., $1278 \mathrm{~N}$

Ruiz, M. L., 894N

Ruiz, T., $1657 \mathrm{~N}$

Rupe, J., 1140, 1517

Rush, C. M., 274, 910

Ruz, L., 1816

Rwahnih, M. Al, 895N, 1656N

Ryegrass. See Lolium multiflorum; Lolium perenne Rysanek, P., 558N

Sánchez-Campos, S., 895N

Sánchez-Navarro, J. A., 1191N

Sabanadzovic, S., 163N, 1347

Sabina przewalskii (Qilian Juniper), Phellinidium qilianense on, in Northwest China, 39

Saccharum spp. (sugarcane)

Alternaria sp. on, in China, $1176 \mathrm{~N}$

Macrophomina phaseolina on, in Mexico, 553N

Phoma sorghina var. saccharum on, in China, 325

Puccinia melanocephala on, screening for resistance with controlled-conditions inoculation, 1633

Sporisorium scitamineum on

flutriafol fungicide for control of, 1367

pathogenic variation in spore populations in Australia, 93

Sadessa, K., 1870N

Saeed, S. T., $155 \mathrm{~N}, 292 \mathrm{~N}$

Saeed, U., 1870N

Sage, common. See Salvia officinalis

Sagittaria sagittifolia (arrowhead), Bacillus amyloliquefaciens on, in China, $1270 \mathrm{~N}$

Saha, S., 527
Saito, S., 1447N

Salamon, P., 898N

Salem, N. M., $1286 \mathrm{~N}$

Salicylhydroxamic acid (SHAM), baseline sensitivity and toxicity of to Sclerotinia sclerotiorum, 267

Salvia officinalis (common sage), Phytophthora cryptoea on, in Italy, 161N

Samac, D. A., 614

Samad, A., 155N, 292N

Samouel, S., 1648N, 1867N

Sánchez-Navarro, J.A., 899N

Sancisi-Frey, S., 1857N

Sandoval-Islas, S., 1153

Sandoya, G. V., 933, 1404, 1713

Sanguansub, S., 225

Sanjuán, S., $1175 \mathrm{~N}$

Sankara, P., 1854N

Sano, T., $1868 \mathrm{~N}$

Sanogo, S., 891N

Sanqi. See Panax notoginseng

Santala, J., 1033N

Sanz, A. V., 1449N

Saparrat, M. C., 1732

Saposhnikovia divaricata (siler)

Botrytis cinerea on, in China, 1277N, 1644N

Pseudomonas viridiflava on, in China, $281 \mathrm{~N}$

Saroj, A., 419N

Sattar, M. N., 732N

Sauer, A. V., 1125

Saurat, C., $1277 \mathrm{~N}$

Savas, N. G., $1855 \mathrm{~N}$

Saville, A., 659

Sawadogo, A., 14

Scandiani, M. M., 502

Scarlet eggplant. See Solanum aethiopicum

Schaefer, J. P., 1210

Schatz, B. G., 1210

Scheck, H. J., 1856N

Scheer, C., 535

Schena, L., 44

Schenck, N., $1277 \mathrm{~N}$

Schmidt, L. S., $1863 \mathrm{~N}$

Schnabel, G., 65, 797, 806, 1537, 1744, 1775

Schneider, R. W., 1596

Scholler, M., $1856 \mathrm{~N}$

Schraber, S., 614

Schultheis, J., 724N

Schultz, A., 1286N

Schwartz, H. F., 1665

Sclerotinia spp.

$S$. homoeocarpa, on creeping bentgrass, in Norway, $287 \mathrm{~N}$

$S$. rolfsii, on bean, in India, $1280 \mathrm{~N}$

S. sclerotiorum

baseline sensitivity of pyraclostrobin and toxicity of SHAM to, 267

on bean: adaptation and common sources of resistance to, 1098; fungicide sensitivity of, 1537

on blanket flower, in Italy, $729 \mathrm{~N}$

on cabbage, in New Mexico, 891N

carmalexin production in Camelina antiva and, 1544

on carnation, in India, $1280 \mathrm{~N}$, Cover photo: Sep

on Crotalaria spectabilis, in Brazil, 1037N on highbush blueberry, in Europe, 1648N

pathogenicity stimulation by subtoxic doses of carbendazim, 1342

on Persian buttercup, in Korea, 1653N, Cover photo: Nov

on rape, effects of the novel fungicide benzothiostrobin on, 969

SCMV. See Sugarcane mosaic virus

Scott, J. B., 1227

SDHI fungicides, for Alternaria alternata on peach

fitness and competitive ability of isolates with resistance to, 1744 
resistance and disease outbreaks, 65

Sechium edule

Podosphaera xanthii on, in Korea, 162N, Cover photo: Jan

Seemüller, E., 1578

Seidl Johnson, A. C., 641

Selastin Antony, R., 1271N

Seleng wormwood. See Artemisia selengensis

Sen, Y., 4

Senecio cruentus (cineraria), Botrytis cinerea on, in Korea, $1865 \mathrm{~N}$

Senegal date palm. See Phoenix reclinata

Sentelhas, P., 310

Senthilkumar, M., 1271N

Senthilraja, C., $1280 \mathrm{~N}$

Seo, J.-K., 292N, 1451N

Sera, G. H., $1285 \mathrm{~N}$

Serçe, Ç. U., $1866 \mathrm{~N}$

Serra, P., 125

Serrano, N., 488

Serratia marcescens, on pumpkin and summer squash, in Georgia, $1175 \mathrm{~N}$

Serrato-Diaz, L. M. 1187N

Sesamum indicum (sesame), watermelon mosaic virus in, in China, $1291 \mathrm{~N}$

Seshadri Goud, T. E., $1287 \mathrm{~N}$

Setaria italica (foxtail millet), Fusarium graminearum on, in China, $1856 \mathrm{~N}$

Setosphaeria turcica, on corn and sorghum, identification and genetic diversity of formae species, 482

Severity estimates, effects of rater accuracy and assessment methods for comparing treatments, 1104

Shabbir, S., $1287 \mathrm{~N}$

Shaffer, C. A., 1147

Shah, D. A., 1360

Shakeel, M. T., 734N, 894N

Shalev, O., 621

SHAM. See Salicylhydroxamic acid

Shan, L. Y., 1276N

Shan, T., $887 \mathrm{~N}$

Shang, W.-J., 1713

Shanmugam, V., 1283N

Shannon, G., 1517

Shao, J., 333

Shao, M., 283N

Shapiro, L. R., 564

Sharma, G., $725 \mathrm{~N}$

Sharma, R., 1784

Sharma-Poudyal, D., 604, 648, 1280N

Sharzei, A., $1186 \mathrm{~N}$

Shears, detection of grapevine fungal trunk pathogens on and evaluation of their potential for spread of infection, 976

Shen, C.-m., 1610

Sheng, J. J., 1449N

Shenge, K. C., $415 \mathrm{~N}$

Shenoy, B. D., 725N

Shew, B. B., 1550

Shi, B. X., 291N

Shi, H. J., 1276N

Shi, Y., 1291N

Shi, Y. J., $1291 \mathrm{~N}$

Shier, W. T., 1236

Shim, H. S., 1640N

Shin, H. D., 158N, 161N, 162N, 556N, 557N, $727 \mathrm{~N}, 728 \mathrm{~N}, 730 \mathrm{~N}, 731 \mathrm{~N}, 889 \mathrm{~N}, 892 \mathrm{~N}$ $1178 \mathrm{~N}, 1179 \mathrm{~N}, 1180 \mathrm{~N}, 1185 \mathrm{~N}, 1273 \mathrm{~N}$, $1648 \mathrm{~N}, 1653 \mathrm{~N}, 1861 \mathrm{~N}, 1863 \mathrm{~N}, 1865 \mathrm{~N}$

Shin, O. J., $292 \mathrm{~N}$

Shivas, R. G., 1182N

Shoaib, A., 1448N

Short, D. P. G., 933, 1183N, 1404, 1713

Shtienberg, D., 496, 1048

Shuey, L. S., 1182N

Shwartz, H., 1048

Sideritis perfoliata, Neoerysiphe galeopsidis on, in Cyprus, $1867 \mathrm{~N}$
Sierotzki, H., 544

Sikirou, R., $1640 \mathrm{~N}$

Silue, D., $735 \mathrm{~N}$

Silva, P., 1153

Silva, R. A., 1537

Silva, S. A., $1285 \mathrm{~N}$

Silver nightshade. See Solanum elaeagnifolium

Simón, A., 894N

Simmons, H. E., 1616, 1847

Simon, S., 1640N, 1656N

Singh, A. K., 1291N

Singh, M., 1283N

Singh, R., 1268N, 1274N

Singh, R. P., 508, 1153

Singh, S., 419N

Singh M., 1658N

Siraitia grosvenorii (luohanguo),

Stagonosporopsis cucurbitacearum on, in China, $1645 \mathrm{~N}$

Sirococcus tsugae, on Atlantic cedar, in Britain, $1857 \mathrm{~N}$

Skantar, A. M., 1188N, 1584

S.Karaoglanidis, 1353

Skoglund, L., 1254

Smart, C. D., 527

Smiley, R. W., 376

Smiljković, M., 1578

Smith, D. L., 347

Smith, D. R., 726N

Smith, J., 1870N

Smith, S. F., 1140

Smith, T., 1284N

Snake gourd. See Trichosanthes cucumerina

Sobolewski, J., 729N

Soil, Plasmodiophora brassicae in, multiplex qPCR assay for detection and quantification of, 1002

Soko, M. M., 420N

Solanum spp.

S. aethiopicum (scarlet eggplant) tomato chlorotic spot virus in, in United States, 1450N, Cover photo: Oct

S. americanum (American nightshade) Pseudocercospora atromarginalis on, in Korea, $727 \mathrm{~N}$

tomato chlorosis virus in, in South America, $895 \mathrm{~N}$

tomato chlorotic spot virus in, in United States, $1450 \mathrm{~N}$

S. betaceum (tamarillo), Euoidium longipes on, in New Zealand, 1863N

S. elaeagnifolium (silver nightshade), as reservoir host for Candidatus liberibacter solanacearum, 910

S. lycopersicum (tomato)

Botrytis cinerea on: population structure, fungicide resistance profile, and $s d h b$ mutation frequency, 240; relationship of conidium concentration to flower and stem infections, 137

Botrytis pseudocinerea on, in China, $283 \mathrm{~N}$ chickpea chlorotic dwarf virus in, in Pakistan, $1287 \mathrm{~N}$

Cladosporium fulvum on, race 0 and race 2 in Argentina, 1732

Clavibacter michiganensis on: Pseudozyma aphidis and induction of salicylic-acidindependence, 621; review of, 4

Fusarium boothii on, in Brazil, 555N, Cover photo: Apr

Meloidogyne incognita on, grafting rootstocks with resistance to Ralstonia solanacearum, 119

Phytophthora infestans on: detached-leaflet evaluation for resistance to, 718 ; fungicides for control of US-22, US-23, and US-24 Isolates, 641

phytoplasma 16 SrII-C on, in Tanzania, $1854 \mathrm{~N}$
Pseudocercospora fuligena on, in Ohio, 285 N, Cover photo: Feb

Pseudomonas spp. on: P. cichorii, in Tanzania, $1035 \mathrm{~N} ;$ P. syringae pv. tomato, genome-assisted development of diagnostic protocol for detecting high virulence strains, 527; $P$. viridiflava, $1033 \mathrm{~N}, 1270 \mathrm{~N}$ tomato chlorotic spot virus in: in Jordan, $1286 \mathrm{~N}$; in Ohio, $163 \mathrm{~N}$

tomato leaf curl New Delhi virus in, in Spain, 894N

tomato yellow leaf curl Mali virus, Tomato leaf curl Mali virus, and pepper yellow vein Mali virus in, in Burkina Faso, $732 \mathrm{~N}$

Xanthomonas euvesicatoria on, in Nigeria, $415 \mathrm{~N}$

S. macrocarpon (ghoma), Ralstonia

solanacearum on, in Benin, 1640N

S. melongena (eggplant)

cucumber mosaic virus in, in Bangladesh, 293N

Podosphaera xanthii on, in China, 1856N

Ralstonia solanacearum Race I Biovar I on, in India, $1271 \mathrm{~N}$

tomato chlorosis virus in, in China, $1657 \mathrm{~N}$

S. sisymbriifolium, tomato chlorosis virus in, in South America, 895N

S. tuberosum (potato)

alfalfa mosaic virus in, in Canada, $1658 \mathrm{~N}$

binucleate Rhizoctonia sp. on, new anastamosis group of, 1757

'Candidatus Liberibacter solanacearum' on, emergence in relation to time of infection, 274

Colletotrichum coccodes on, extended crop rotations and, 257

modeling DNA content and visual disease assessment in seed tubers, 50

Pectobacterium carotovorum subsp. brasiliense on: in Poland, 1271N; in Switzerland, 551N

Phytophthora infestans on: clonal lineage US23 , in Idaho, 417N; fungicide sensitivity of U.S. genotypes to six oomycete-targeted compounds, 659; rain forecasts for scheduling management tactics, 683

Phytophthora nicotianae on, etiology of, 474

potato mop top virus in: in Colorado and New Mexico, 164N; cultivar sensitivity, 788

potato virus $Y$ in, contact transmission, stability, inactivation, and infection sources, 387

Rhizoctonia solani and binucleate Rhizoctonia, anastomosis groups and pathogenicity, 1790

Spongospora subterranea f. sp. subterranea on, effect of root galls on yield, 1396

Synchytrium endobioticum on, in Poland, 285N tomato spotted wilt virus in, in Korea, $1657 \mathrm{~N}$ tomato zonate spot virus in, in China, 733N

Verticillium dahliae on, extended crop rotations and, 257

Verticillium tricorpus on, in Australia, 731N Son, T. B., $1278 \mathrm{~N}$

Song, J. G., 1038N

Song, W., 1118

Song, W.-W., 554N

Song, Y. L., 156N

Sorghum bicolor, Setosphaeria turcica on, identification and genetic diversity of formae species, 482

Sorrentino, R., $1655 \mathrm{~N}$

Soukainen, M., 1033N

Sow, M., 735N

Soybean. See Glycine max

Soybean mosaic virus (SMV), screening isolates

for infectivity in Nicotiana benthamiana, 442

Spadaro, D., $1648 \mathrm{~N}$

Spagnolo, A., 1859N

Speedwell, Persian. See Veronica persica

Sphacelotheca reiliana, on maize, real-time PCR assay for detection in seedlings and evaluation of treatment efficiency, 1847

Sphaerulina tirolensis 
on wineberry, in United States, $1275 \mathrm{~N}$, Cover photo: Sep

Spider lily. See Crinum asiaticum

Spilocaea oleagina, on olive, susceptibility of new cultivars, 58

Spinach. See Spinacia oleracea

Spinach, tree. See Cnidoscolus chayamansa

Spinacia oleracea (spinach)

Alternaria alternata on, in Poland, 729N

Fusarium oxysporum f. sp. spinaciae on, soil bioassay for risk prediction, 512

Leveillula taurica on, in California, $555 \mathrm{~N}$

Pythium aphanidermatum on, in Italy, 159N

Verticillium klebahnii and $V$. isaacii on, host range of, 933

Spiroplasma citri

on celery, in Spain, $1175 \mathrm{~N}$

on citrus, real-time PCR targeting prophage genes of, 149

Spolti, P., 1360

Sponge gourd. See Luffa cylindrica

Spongospora subterranea f. sp. subterranea, on potato, effect of root galls on yield, 1396

Sporisorium scitamineum, on sugarcane

flutriafol fungicide for control of, 1367

pathogenic variation in spore populations in Australia, 93

Spotted locoweed. See Astragalus lentiginosus

Spruce, Engelmann. See Picea engelmanii

SPSMV-1. See Sweetpotato symptomless virus 1

Spurlock, T. N., 554N, 836

Squash. See Cucurbita spp.

Squash vein yellowing virus (SqVYV), in

cucurbits, in California, 1042N

Sreenivasa, M. Y., 1641N, 1868N

Srivastava, A., 627

Srivastava, A. K., 419N

St. Augustine grass. See Stenotaphrum secundatum Stagonosporopsis spp.

S. cucurbitacearum, on luohanguo, in China, $1645 \mathrm{~N}$

S. tanaceti, on pyrethum, changes in distribution and frequency of fungi associated with a foliar disease complex, 1227

Stamler, R. A., 1468, 1854N

Stammler, G., 1078

Standish, J. R., 1347

Stanković, I., 286N, 709, 736N, 894N, 896N, $1450 \mathrm{~N}, 1869 \mathrm{~N}$

Stanojkovic-Sebic, A., $283 \mathrm{~N}$

Stanosz, G. R., 726N

Starovic, M., 283N, 1279N

Stellaria aquatica, overwintering of tomato yellow leaf curl virus in, 588

Stemphylium vesicarium, on pear, synthetic

antimicrobial peptide for control of, 1816

Stenocarpella $\mathrm{spp}$

S. macrospora, on corn, molecular assays for detection of, 761

S. maydis, on corn, molecular assays for detection of, 761

Stenotaphrum secundatum (St. Augustinegrass)

Sugarcane mosaic virus in, in Florida, 557N

Trichodorus obtusus on, in North Carolina, $291 \mathrm{~N}$

Stephens-Cárdenas, S. A., 1855N

Stephenson, A. G., 1616

Stevic, T., $1279 \mathrm{~N}$

Stewart, J., 355

Stojšin, V., 281N

Stolbur phytoplasma

on sweet William, in Serbia, 283N, Cover photo: Feb

Stone, C., $418 \mathrm{~N}$

Stone fruit. See Prunus spp.

Strausbaugh, C. A., 1296

Strawberry. See Fragaria $\times$ ananassa

Strehlow, B., 667

Strelkov, S. E., 776
Streptomyces acidiscabies, on white radish, in China, $1035 \mathrm{~N}$

Stringer, J. K., 93

Struck, C., 667

Stulberg, M. J., 333

Stump, W. L., 355

Su, H. N., 320

$\mathrm{Su}, \mathrm{H} .-\mathrm{R} ., 286 \mathrm{~N}$

Suárez-Rodríguez, R., 555N

Suasa-ard, W., 225

Subbarao, K. V., 933, 1404, 1713

Subedi, N., $285 \mathrm{~N}$

Subramanian, S., 899N

Succinate dehydrogenase, Alternaria alternata on tangerine and, 231

Sudiana, I. M., 225

Sugar beet. See Beta vulgaris

Sugar maple. See Acer saccharum

Sugarcane. See Saccharum spp.

Sugarcane mosaic virus (SCMV)

in finger millet, in Kenya, 899N

in St. Augustinegrass, in Florida, 557N

Sugiyama, L. S., $1276 \mathrm{~N}$

Sullenberger, M. T., 718

Sun, B. J., $1291 \mathrm{~N}$

Sun, F., 219

Sun, G., 219

Sun, G. W., 888N

Sun, H., 1118, 1653N

Sun, H.-y., 1610

Sun, L., 1177N

Sun, M., $731 \mathrm{~N}$

Sun, R., 776

Sun, S., 887N

Sun, X., 699

Sun, X. H., 1288N

Sun, Y., 1118

Sun, Y. F., 1868N

Sun, Y. H., 1192N

Sunflower. See Helianthus annuus

Sunflower broomrape. See Orobanche cumana

Suto, Y., 740

Sutton, W., 727N, 1133, 1282N

Svanella-Dumas, L., 421N

Svoboda, J., 558N

Swedish ivy. See Plectranthus verticillatus

Sweet basil. See Ocimum basilicum

Sweet cherry. See Prunus avium

Sweet orange. See Citrus sinensis

Sweet viburnum. See Viburnum odoratissimum

Sweet William. See Dianthus barbatus

Sweetpotato. See Ipomoea batatas

Sweetpotato symptomless virus 1 (SPSMV-1), in sweetpotato, in China, $1042 \mathrm{~N}$

Swisher, K. D., 1269N

Synchytrium endobioticum, on potato, in Poland, $285 \mathrm{~N}$

Syringa 'Charisma' (lilac), 'Candidatus

Phytoplasma pruni,' on, $886 \mathrm{~N}$

Szurek, B., 551N, 1853N

Szydlo, W., 1290N

Türkölmez, Ş., 1866N

Taberner, V., 1416

Taghouti, G., $551 \mathrm{~N}$

Takano, H. K., 1037N

Takikawa, Y., $1445 \mathrm{~N}$

Tamarillo. See Solanum betaceum

Tamindžić, G., 1277N

Tan, G. L., 734N

Tan, J., 320

Tan, W. P., $888 \mathrm{~N}, 1288 \mathrm{~N}$

Tan, X. F., 419N

Tanacetum cinerariifolium (pyrethrum), Stagonosporopsis tanaceti on, changes in distribution and frequency of fungi associated with a foliar disease complex, 1227

Tanaka, K., $1445 \mathrm{~N}$
Tande, C., $1176 \mathrm{~N}$

Tang, C. Y., 158N

Tang, L., 482

Tang, Q., 1864N

Tang, Q.-H., 554N

Tangerine. See Citrus reticulata Blanco

Tanguay, P., 1374

Tanina, K., 409

Tannières, M., 293N, 422N

Tanović, B., 709

Tao, X. R., 164N

Tapia-Tussell, R., 1590

Tarazona, I., 1416

Taro. See Colocasia esculenta

Tatineni, S., 1170

Taylor, P. W. J., 731N

Taylor, R. J., 474

TCSV. See Tomato chlorotic spot virus

Tea. See Camellia sinensis

Tectona grandis (teak), Alternaria alternata on in China, $887 \mathrm{~N}$

Tege, J., $1033 \mathrm{~N}$

Tegg, R. S., 50

Teixeira, H., 1098

Tejaswini, G. S., 1280N

Tekete, C., $551 \mathrm{~N}, 1445 \mathrm{~N}$

Teklewold, A., $1870 \mathrm{~N}$

Temple, T. N., 1147

Tenreiro, R., $282 \mathrm{~N}$

Tenuta, A. U., 347

Teodorović, S., 894N

Tephrosia vogelii, Meloidogyne javanica on, in Brazil, $1285 \mathrm{~N}$

Teratosphaeria pseudoeucalypti, on eucalyptus hybrids, in Argentina, 554N

Terzi, 896N

Testen, A. L., 285N, 1035N, 1854N

Tewoldemedhin, Y. T., 1020

Thaker, V. S., 1640N

Thakur, D., $417 \mathrm{~N}$

Thakur, H., $1283 \mathrm{~N}$

Thakur, R. P., 1784

Thiabendazole, for Colletotrichum truncatum, resistance to, 1590

Thielaviopsis thielavioides, on carrot, in Serbia, $1274 \mathrm{~N}$

Thinakaran, J., 910

Thiophanate-methyl (THM)

for Colletotrichum siamense on peach and blueberry, 806

for Sclerotinia sclerotiorum on bean, assessment of sensitivity of, 1537

Tho, K. E., 1034N

Thomas, C., 310

Thuong, N. T. T., $1276 \mathrm{~N}$

Thuy, T. T. T., $1278 \mathrm{~N}$

Thymus vulgaris (thyme), Colletotrichum destructivum on, in Florida, 1184N

Thyronectria pinicola, on Pinus radiata, in Australia, $1182 \mathrm{~N}$

Tian, T., $1042 \mathrm{~N}$

Tian, Y., $1175 \mathrm{~N}$

Tian, Y.-T., 1042N

Timilsina, S., 415N, 874

Tlapal-Bolaños, B., 553N

TLYCV. See Tomato yellow leaf curl virus

TM. See Thiophanate-methyl

Tobacco ringspot virus (TRSV), in grape, in Washington state, $1286 \mathrm{~N}$

ToCV. See Tomato chlorosis virus

Toda, T., 1823, 1857N

Tok, F. M., $1181 \mathrm{~N}$

ToLCABV. See Tomato leaf curl Albatinah virus

ToLCGuV. See Tomato leaf curl Gujarat virus

ToLCMLV. See Tomato leaf curl Mali virus

ToLCNDV. See Tomato leaf curl New Delhi virus

Tomaso-Peterson, M., 1347

Tomato. See Solanum lycopersicum

Tomato, husk. See Physalis pubescens 
Tomato chlorosis virus (ToCV) in eggplant, in China, $1657 \mathrm{~N}$ in Solanum sisymbriifolium and S. americanum, in South America, 895N in tomato

in Jordan, 1286N

in Ohio, $163 \mathrm{~N}$

Tomato chlorotic spot virus (TCSV)

in scarlet eggplant and American black nightshade, in United States, 1450N, Cover photo: Oct

in vinca, in United States, 895N

Tomato leaf curl Albatinah virus (ToLCABV), in papaya, in Oman, $421 \mathrm{~N}$

Tomato leaf curl Gujarat virus (ToLCGuV), in Gossypium hirsutum, in Pakistan, 1655N

Tomato leaf curl Mali virus (ToLCMLV), in tomato, in Burkina Faso, 732N

Tomato leaf curl New Delhi virus (ToLCNDV), in tomato, in Spain, 894N

Tomato spotted wilt virus (TSWV)

in celery, in China, $734 \mathrm{~N}$

in chrysanthemum, in India, 1190N

in pepper

resistance and, $1869 \mathrm{~N}$

in Venezuela, 896N

in potato, in Korea, $1657 \mathrm{~N}$

Tomato yellow leaf curl Mali virus (TYLCMLV), in tomato, in Burkina Faso, $732 \mathrm{~N}$

Tomato yellow leaf curl virus (TYLCV),

overwintering of in Stellaria aquatica, 588

Tomato zonate spot virus (TZSV)

in Iris tectorum, in China, $164 \mathrm{~N}$

in potato, in China, $733 \mathrm{~N}$

Tompkins, D. V., $1645 \mathrm{~N}$

Toome, M., $1863 \mathrm{~N}$

Torchetti, E. M., 1655N

Torenia fournieri (wishbone flower),

Podosphaera xanthii on, in Korea, 1863N

Torre-Almaráz, R. De La, 1191N

Torres-Calzada, C., 1590

Toševski, I., 551N, 1035N, 1274N, 1645N

Tossa jute. See Corchorus olitorius

Tovar-Pedraza, J. M., 553N

Tran, H. S., 580

Tran, T. T., $1853 \mathrm{~N}$

Tranzschelia mexicana, on capulin cherry, in United States, $1856 \mathrm{~N}$

Trapero, A., 58

Trapero-Casas, J. L., 962

Tredway, L., 982

Tree spinach. See Cnidoscolus chayamansa

Trehalose-based quantification, of live eggs in

Globodera rostochiensis and $G$. pallida, 947

Trentepohiales, as plant pathogens, 740, Cover photo: Jun

Trichoderma viride, on Pinus nigra, in Italy, 44

Trichodorus obtusus, on turfgrasses, in North

Carolina, 291N

Trichosanthes cucumerina (snake gourd)

cucumber green mottle mosaic virus in, in India, 559N

zucchini yellow mosaic virus in, in India, $558 \mathrm{~N}$

Trichothecium roseum, on trident maple, in China, 1864N

Trident maple. See Acer buergerianum

Trifloxystrobin, Fusicladium carpophilum on peach and nectarines and, 467

Trifolium repens (white clover), Erysiphe trifoliorum on, in Korea, $1276 \mathrm{~N}$

TriMV. See Triticum mosaic virus

Triticale, brome mosaic virus and Wheat streak mosaic virus coinfection in, $1290 \mathrm{~N}$

Triticum mosaic virus (TriMV), impact of coinfection of wheat with on transmission rates by white curl mites, 1170

Triticum spp.

T. aestivum (wheat)
Aceria tosichella on: effects of soil nitrogen and atmospheric carbon dioxide on, 1803; impact of wheat streak mosaic virus and triticum mosaic virus coinfection of wheat on transmission rates by, 1170

Alternaria tenuissima and Alternaria infectoria on, in Serbia, $1647 \mathrm{~N}$

Blumeria graminis f. sp. tritici on, 395 1118

Fusarium spp. on: $F$. graminearum species complex, 1360, 1622; F. pseudograminearum, in North China Plain, 156N; survey of in winter wheat growing regions of China, 1610

Heterodera filipjevi on, in Montana, $1188 \mathrm{~N}$

Magnaporthe oryzae on, in Argentina, 1177N

Parastagonospora nodorum on, evaluation and association mapping of resistance to, 1333

Puccinia spp. on: P. graminis f. sp. tritici, 508, 754, 1317; P. striiformis, 1153 , 1764; P. triticina, 1153, 1261

Pyrenophora tritici-repentis on, evaluation and association mapping of resistance to, 1333

wheat spindle streak mosaic virus in, in Croatia, $896 \mathrm{~N}$

wheat streak mosaic virus in, effects of soil nitrogen and atmospheric carbon dioxide on, 1803

Fusarium redolens on, in Turkey, $1280 \mathrm{~N}$

T. turgidum (durum wheat), Puccinia triticina on, in Great Plains region, $156 \mathrm{~N}$

Trkulja, N., 724N, 1035N, 1274N, 1645N

Trucco, V., $735 \mathrm{~N}$

Truter, M., 290N, 1790

Trzmiel, K., 1290N

Tsai, J. N., 1649N

Tsuji, M., $1445 \mathrm{~N}$

TSWV. See Tomato spotted wilt virus

Tubakia seoraksanensis, on Mongolian oak, in China, 891N

Tucker, G. R., 1367

Turfgrasses. See also Specific turfgrasses

molecular characterization and phylogenetic relationships of plant-parasitic nematodes associated with in North and South Carolina, 982

Paspalum vaginatum, Gaeumannomyces graminis on, in China, $1858 \mathrm{~N}$

Turnip yellows virus (TuYV)

in oilseed rape, in Serbia, $1869 \mathrm{~N}$

in tobacco, in China, $1870 \mathrm{~N}$

Twomey, M. C., 858

TYLCMLV. See Tomato yellow leaf curl Mali virus

Typas, M. A., 286N

Tzanetakis, I. E., 176

TZSV. See Tomato zonate spot virus

Udagama, P., 1642N

Ug99 race group of Puccinia graminis $\mathrm{f}$. sp. tritici, resistance of wheat hybrid derivatives to, 1317

Ul Haq, M. I., 1870N

Ulocladium chartarum, on lemon verbena, in Iran, $1186 \mathrm{~N}$

Ulvophyceae, as plant pathogens, 740, Cover photo: Jun

Upadhyaya, H. D., 1784

Uraichuen, S., 225

Urrea, C. A., 1665

Ustilago spp. See also Sporisorium scitamineum

$U$. maydis, on corn, aflatoxin and fumonisin production and, 1236

Vaccinium spp. (blueberry)

Colletotrichum karstii on, in Brazil, 157N

V. corymbosum

Colletotrichum siamense on, resistant to thiophanate-methyl and azoxystrobin, 806

Corynespora cassiicola on, in China, $1651 \mathrm{~N}$
Sclerotinia sclerotiorum on, in Europe, 1648N

Vaillancourt, L. J., 1622

Vakalounakis, D. J., 1649N, 1867N

Vale, F. X. R., 1216

Valerianella olitoria (lamb's lettuce), Pythium irregulare on, in Italy, $1650 \mathrm{~N}$

Vallad, G. E., 415N, 874

Van Bruggen, A. H. C., 300

Van der Heyden, H., 137, 1010

Van der Waals, J. E., 1790

Van der Wolf, J., 4

Van Heusden, S., 4

Van Sanford, D., 1622

Vannini, A., 1133

Varga, A., $558 \mathrm{~N}$

Vargas Jr., J. M., 1270N

Vargas-Hernández, M., 1153

Vayssières, J. F., 1854N

Veetil, T. T., 421N

Vega, B., 231

Velázquez-del Valle, M. G., 555N

Velázquez-Martínez, G. C., 553N

Velasco, L., 894N

Veloukas, T., 240

Velvet plant, purple. See Gynura aurantiaca

Vemana, K., 1287N

Venturia inaequalis, on Malus spp.

Cladosporium cladosporioides H39 for control of, 535

effect of delayed-dormant chemical treatments on demethylation inhibitor sensitivity, 1751 prevalence of myclobutanil resistance and difenoconazole insensitivity in populations of, 1526

virulence of reference isolates on different hosts, 370

Verbena, lemon. See Lippia citriodora

Verchot, J., 188, 1695

Verdier, V., 551N, $1445 \mathrm{~N}$

Verma, G., $1268 \mathrm{~N}$

Veronica persica (Persian speedwell), Ramularia veronicae on, in Korea, 1178N

Vertical transmission, of zucchini yellow mosaic virus, transgenic resistance in Cucurbita pepo and, 1616 Verticillium spp.

V. dahliae

on cotton, nondefoliating and defoliating strains correlate with races 1 and 2, 1713 on olive, irrigation frequency and, 488 on Paulownia spp., symptomless host and nonhost responses, 962

on pepper, screening of wild and cultivated germplasm for new sources of resistance, 1404

on potato, extended crop rotations and, 257

on woody hosts, real-time PCR method for detection and monitoring of, 866

V. isaacii, from artichoke, spinach, and lettuce, host range of, 933

V. klebahnii, from artichoke, spinach, and lettuce, host range of, 933

$V$. nonalfalfae, for control of tree-of-heaven, 823, 1070, Cover photo: Jun

V. tricorpus, on potato, in Australia, $731 \mathrm{~N}$

Vetch, common. See Vicia sativa

Vettraino, A. M., 1133

Viaene, N., 947

Viburnum spp.

V. edule (highbush cranberry), Puccinia linki on, in Alaska, 893N

V. odoratissimum (sweet viburnum), Colletotrichum gloeosporioides on, in China, $1647 \mathrm{~N}$

Vicia spp.

$V$. faba (broad bean), on broad bean, PCRbased assays for detecting and differentiating three species, 691

V. sativa (common vetch), Colletotrichum lentis on, in China, $1859 \mathrm{~N}$ 
Vico, I., $1182 \mathrm{~N}$

Vida, J. B., 1037N

Vidalakis, G., 176

Vidić, M., $1186 \mathrm{~N}$

Vieira, R. F., 1098, 1537

Vigna spp.

V. angularis (red adzuki bean), Pantoea agglomerans on, in China, $1269 \mathrm{~N}$

V. unguiculata (yardlong bean), cowpea mild mottle virus in, in Venezuela, $1657 \mathrm{~N}$

Villalobos-Müller, W., $1855 \mathrm{~N}$

Villalobos-Navarro, D., 1855N

Villani, S. M., 1374, 1526, 1751

Villinger, J., 899N

Villordon, A. Q., 848

Vincelli, P., 263, 866

Vinod Kumar, S., 1279N, 1280N

Viola odorata (violet), Cercospora violae on, in Serbia, $1035 \mathrm{~N}$

Visser, R. G. F., 4

Vitale, S., $155 \mathrm{~N}$

Vitis spp.

V. aestivalis (summer grape), Grapevine leafrollassociated virus 2 in, in United States, 163N

V.amurensis (Amur grape), Fusarium avenaceum on, in China, $889 \mathrm{~N}$

$V$. heyneana, Neofusicoccum parvum on, in China, $417 \mathrm{~N}$

V. rotundifolia (muscadine grape), Grapevine leafroll-associated virus 2 in, in United States, $163 \mathrm{~N}$

$V$. vinifera (grape)

Botryosphaeriaceous fungi on, characterization of as causal agents of trunk diseases, 1678

Botrytis cinerea on, isolation of boscalid resistant isolates carrying the mutations H272R, H272Y, P225L, and P225H, 891N

'Candidatus Phytoplasma pruni' on, novel NAGY phytoplasma sequevars related to, 1087, Cover photo: Aug

detection of grapevine fungal trunk pathogens on pruning shears and evaluation of their potential for spread of infection, 976

Fusarium proliferatum on, in China, $1180 \mathrm{~N}$ grapevine Pinot gris virus in, in France, 293N grapevine red blotch-associated virus in, in California, 895N

grapevine redglobe virus in, in France, $422 \mathrm{~N}$ grapevine virus A, grapevine fleck virus, and grapevine leafroll-associated virus 1 in, in United Kingdom, 898N

Ilyonectria liriodendri on, in Turkey, $1855 \mathrm{~N}$

Neofusicoccum parvum on, in France, 1859N

tobacco ringspot virus in, in Washington state, $1286 \mathrm{~N}$

Vončina, D., 1656N

Vrandečić, K., 896N

Vučurović, A., 286N, 894N, 896N, 1450N

Vučurović, I., 894N, 1450N

Vukojević, J., 730N

Walenta, D. L., 1410

Waleron, K., 1271N

Waleron, M., $1271 \mathrm{~N}$

Walker, D. R., 1059

Walker, L., $1286 \mathrm{~N}$

Wallace, E., $1861 \mathrm{~N}$

Walnut. See Juglans regia

Walter-Peterson, H., 1087

Walters, T. W., 939

Wampee. See Clausena lansium

Wan, A. M., 1507

Wan, B. J., $1189 \mathrm{~N}$

Wan, Q., 1764

Wan, S. L., $1642 \mathrm{~N}$

Wang, B., 249

Wang, C. W., $889 \mathrm{~N}, 1037 \mathrm{~N}, 1180 \mathrm{~N}, 1644 \mathrm{~N}$

Wang, C.-X., 249
Wang, D., 219, 893N, 1285N

Wang, F., 1870N

Wang, F. L., $1448 \mathrm{~N}$

Wang, G., 1704

Wang, G. Z., 287N

Wang, J., 887N, 1176N, 1241

Wang, J. H., 325, 1179N

Wang, J. M., $156 \mathrm{~N}$

Wang, J.-F., 282N

Wang, J.-H., $160 \mathrm{~N}$

Wang, K. X., $725 \mathrm{~N}$

Wang, L., 1113, 1177N

Wang, L. H., 1179N, 1187N, 1282N

Wang, L.-J., 1184N

Wang, M., 164N

Wang, M. N., 1500, 1507

Wang, N., $1856 \mathrm{~N}$

Wang, P., 1569

Wang, P. S., 284N

Wang, Q., 1192N

Wang, Q. L., 754

Wang, S., 1042N, 1642N

Wang, S. J., $1858 \mathrm{~N}$

Wang, S. T., 553N

Wang, X., 149, 325, 1118, 1175N, 1569, 1644N

Wang, X. M., $1643 \mathrm{~N}$

Wang, X. Q., 557N

Wang, Y., 281N, 557N, 1180N, 1644N, 1654N

Wang, Y. F., $290 \mathrm{~N}$

Wang, Y. N., 553N

Wang, Y. Q., $1282 \mathrm{~N}$

Wang, Y. X., 1036N

Wang, Y. Y., 893N

Wang, Y. Z., 284N, 1291N

Wang, Y.-J., 1042N

Wang, Z., 1113

Wang, Z. R., $1287 \mathrm{~N}$

Wang, Z. Y., $1291 \mathrm{~N}$

Wangai, A., $1870 \mathrm{~N}$

Wanjala, B., $1870 \mathrm{~N}$

Ward, L. I., $898 \mathrm{~N}$

Ward, T., 1622

Ward, T. J., $1859 \mathrm{~N}$

Warfield, C. Y., 895N

Washington navel sweet orange trees. See Citrus sinensis

Watermelon. See Citrullus lanatus

Watermelon mosaic virus (WMV)

in Cucurbita pepo, in Libya, $558 \mathrm{~N}$

in sesame, in China, $1291 \mathrm{~N}$

Weather conditions

Glomerella cingulata on apple and, 249

impacts of on infection efficiency of Bremia lactucae on lettuce, 1010

leaf wetness duration determination for plant disease management, 310

Ophiognomonia clavigignenti-juglandacearum on butternut, influence of temperature and humidity on conidia viability, 1841

Phytophthora infestans on potato, rain forecasts for scheduling management tactics, 683

Rhizopus stolonifer and Dickeya dadantii on sweetpotato and, 848

Weather-based forecasting, of Rhizoctonia AG-U

on container-grown azalea, 100

Weaver, M. A., 1236

Webb, M. A., 188, 1695

Wegary, D., $1870 \mathrm{~N}$

Wegulo, S. N., 1170

Wei, J., $1176 \mathrm{~N}$

Wei, J. G., 419N

Wei, J. J., 325

Wei, J. M., 288N

Wei, M. S., 735N, $1191 \mathrm{~N}$

Wei, W., 1087

Wei, Y.-X., 288N

Weiland, J. E., 157N, 939

Weimer, J., 1374

Welliver, R. A., 176
Wen, X., 725N

Wen, Z., 87

Wharton, P. S., $417 \mathrm{~N}$

Wheat. See Triticum spp.; Triticum turgidum

Wheat (Triticum aestivum)

Fusarium sacchari on, in China, 160N

soft red winter, revisiting fungicide-based management guidelines for leaf blotch diseases in, 1434

wheat streak mosaic virus in, susceptibility and tolerance of multiple isolates, 1383

Wheat spindle streak mosaic virus (WSSM), in wheat, in Croatia, 896N

Wheat streak mosaic virus (WSMV)

impact of coinfection of wheat with on transmission rates by white curl mites, 1170

in triticale, coninfection with brome mosaic virus, $1290 \mathrm{~N}$

in wheat, effects of soil nitrogen and atmospheric carbon dioxide on, 1803

in wheat and barley, susceptibility and tolerance of multiple isolates, 1383

Whitaker, V. M., 954

White clover. See Trifolium repens

White pine. See Pinus strobus

White radish. See Raphanus sativus

Whitestem filaree. See Erodium moschatum

Wicker, E., $1445 \mathrm{~N}, 1640 \mathrm{~N}$

Widmer, T. L., 460, 1204

Wiechel, T. J., 50, 731N

Wijayasekara, D., 1695

Wijeratnam, R. S. W., $1858 \mathrm{~N}$

Wild bitter gourd. See Momordica charantia

Wild palm. See Phoenix reclinata

Wild rocket. See Diplotaxis tenuifolia

Willhauck, A., 1269N

Williams, M. A., 564

Williams, N., 727N

Williamson, M., 1274N

Willyerd, K. T., 1434

Wilson, C. R., 50

Wineberry. See Rubus phoenicolasius

Wintercreeper. See Euonymus fortunei var. radicans

Wintermantel, W. M., 1042N

Wiriyajitsomboon, P., 1034N

Wise, K. A., 347, 761, 1434

Wiseman, M. S., 201

Wishbone flower. See Torenia fournieri

Wisteria sinensis

Erysiphe diffusa on, in China, 1272N, Cover photo: Sep

Withers, S., 724N

WMV. See Watermelon mosaic virus

Wolf, T. K., 1087

Wolfenbarger, S. N., 858

Wonni, I., $551 \mathrm{~N}, 1854 \mathrm{~N}$

Wood, B. W., 916

Woodhall, J. W., 1790

Woods, J. L., 858

Workneh, F., 274

Wormwood, Seleng. See Artemisia selengensis

Wrather, A., 1517

WSMV. See Wheat streak mosaic virus

WSSM. See Wheat spindle streak mosaic virus

$\mathrm{Wu}$, A.-B., $160 \mathrm{~N}$

Wu, B., $1191 \mathrm{~N}$

Wu, D. D., $417 \mathrm{~N}$

Wu, F., $887 \mathrm{~N}$

Wu, J. H., 754

Wu, J. X., 284N, 1448N

Wu, L. F., $1190 \mathrm{~N}$

Wu, M., 691, 1426

Wu, M. D., 283N

Wu, Q. F., $1870 \mathrm{~N}$

Wu, X. H., 1757

Wu, Y. J., $289 \mathrm{~N}$

Wu, Y. M., 1177N

Wu, Z. J., $1189 \mathrm{~N}$

Wullschleger, J., 544 
Xanthis, C. K., 894N

Xanthomonas spp.

$\mathrm{X}$. axonopodis

on poinsettia, multilocus sequence analysis for genetic diversity of, 874

pv. dieffenbachiae, on crystal anthurium, in China, $1268 \mathrm{~N}$

pv. manihotis: on cassava, in Burkina Faso, 551N; on cassava, in Ivory Coast, $1445 \mathrm{~N}$

X. campestris pv. raphani $(X c r)$, on Brassica oleracea, in Portugal, $282 \mathrm{~N}$

X. citri

pv. citri, on citrus, comparison of resistance among different citrus genotypes, 207

pv. mangiferaeindicae, on mango, in Benin, $1854 \mathrm{~N}$

$X$. euvesicatoria

on hot pepper, in Korea, $1640 \mathrm{~N}$ on tomato, in Nigeria, $415 \mathrm{~N}$

$X$. oryzae pv. oryzicola, on rice, in Vietnam, $1853 \mathrm{~N}$

$X$. translucens, on perennial ryegrass, in United States, $1270 \mathrm{~N}$

Xiang, H. Y., 1192N

Xiang, Y., 502

Xiao, C. L., 201, 1447N, 1642N

Xiao, L., 734N

Xiao, S., 420N

Xiao, S. Q., 290N

Xie, G. H., 1654N

Xie, H., $1175 \mathrm{~N}$

Xie, J., $1185 \mathrm{~N}$

Xie, J. T., 1647N

Xie, K. Q., $1449 \mathrm{~N}$

Xie, L. H., 284N

Xie, W. J., $1179 \mathrm{~N}$

Xie, Y., 557N, 1182N, 1652N, 1653N

Xie, Y. L., $725 \mathrm{~N}$

$\mathrm{Xu}, \mathrm{B} ., 1038 \mathrm{~N}$

$\mathrm{Xu}$, B. C., $1284 \mathrm{~N}$

Xu, C., 969

Xu, D. F., $1870 \mathrm{~N}$

$\mathrm{Xu}, \mathrm{F} ., 156 \mathrm{~N}$

Xu, J., 725N, 1184N, 1651N

$\mathrm{Xu}$, J. P., $1276 \mathrm{~N}$

$\mathrm{Xu}, \mathrm{K} . \mathrm{Y} ., 1276 \mathrm{~N}$

$\mathrm{Xu}$, L.-H., $1650 \mathrm{~N}$

$\mathrm{Xu}, \mathrm{M} . \mathrm{L}, 284 \mathrm{~N}, 1448 \mathrm{~N}$

$\mathrm{Xu}, \mathrm{S} ., 1859 \mathrm{~N}$

$\mathrm{Xu}$, S. Q., 325

$\mathrm{Xu}, \mathrm{W} ., 1704$

Xu, X., 395

$\mathrm{Xu}, \mathrm{X} . \mathrm{C} ., 1862 \mathrm{~N}$

$\mathrm{Xu}$, X. L., $1189 \mathrm{~N}$

$\mathrm{Xu}, \mathrm{X} .-\mathrm{D} ., 1184 \mathrm{~N}$

$\mathrm{Xu}$, Y. C., $283 \mathrm{~N}$

$\mathrm{Xu}, \mathrm{Z} . \mathrm{H} ., 1276 \mathrm{~N}$

Xue, C. S., $290 \mathrm{~N}$

Xue, S. M., 890N

Xue, W. B., 754

Xylella fastidiosa, emergence of diseases caused by, 1457

Yadav, V., 1280N, 1641N

Yan, G. P., 376

Yan, J. Y., 1657N

Yan, S., 731N

Yan, W., 1038N, 1040N

Yan, Z., 1584

Yan, Z. L., 1291N

Yang, C. D., 281N

Yang, D. J., 1035N

Yang, F. Y., 1035N

Yang, G. Q., 156N

Yang, H. R., 1864N

Yang, H.-C., 143, 1559

Yang, J. D., 1287N
Yang, J. G., 284N, 1448N

Yang, J. H., 65, 1744

Yang, L., 283N, 691, 1426, 1652N

Yang, L. N., 1644N

Yang, M. Y., 890N

Yang, W. T., 1189N

Yang, X., 342, 1390

Yang, X. B., 419N

Yang, X. H., 419N

Yang, X. X., 1647N

Yang, X.M., 1179N

Yang, X.-P., 1488

Yang, Y. G., 1757

Yang, Y. M., 889N, 1037N, 1644N

Yang, Z. X., 557N

Yao, D., 395

Yao, J., 1113

Yao, J. A., 1652N

Yao, R. Y., 1654N

Yao, Y., 482

Yardlong bean. See Vigna unguiculata

Yasuda, N., 904

Ye, W., 291N, 982

Ye, Y. F., 417N, 1645N

Yin, L., 1775

Yin, Y., 1651N

Yokomi, R. K., 149

Yonts, C. D., 1665

Yoon, M.-J., 1640N

Yoon, Y.-N., 1189N

You, H., 267

You, M. P., 112, 580

Yr24 (Yr26) gene, emerging Puccinia striiformis f. tritici virulent races on wheat in China, 754

Yr60 gene, resistance against Puccinia striiformis f. sp. tritici on wheat and, 508

Yu, D. Y., 1652N

$\mathrm{Yu}$, D.C., 283N

Yu, F.-Y., 554N, 1040N

Yu, H. Q., 164N, 733N

Yu, H.-s., 1610

Yu, J., 1182N

Yu, S. F., 1654N

Yu, X., 725N, 1449N, 1651N

Yu, X. L., 284N

Yu, X. M., 1035N

Yuan, G. Q., 725N

Yuan, H. S., 39

Yuan, Y., 1277N, 1285N

Yue, J. Q., 1287N

Yue, S. S., 1647N

Yun, H. Y., 1447N

Yun, H.-T., 1189N

Zablotowicz, R. M., 1236

Zaidi, S. S. A., 1655N

Zakaria, L., $1650 \mathrm{~N}$

Zambrano, K., 896N, 1190N, 1657N

Zamora, P., 1449N

Zanini, A., 733N

Zantedeschia ellitiona (calla lily), Fusarium solan on, in India, $1283 \mathrm{~N}$

Zanutto, C. A., 1125

Zarzyńska-Nowak, A., 1290N

Zasada, I. A., 939

Zasmidium lythri, on purple loosestrife, in Korea, $728 \mathrm{~N}$

Zdravkovic, M., 283N

Zea mays (corn)

Clavibacter michiganensis subsp. nebraskensis on

in Canada, $1034 \mathrm{~N}$

in Louisiana, $1268 \mathrm{~N}$

fungicides in, influence of open alleys in field trials assessing yield effects from, 263

Fusarium graminearum species complex (FGSC) on wheat following, disease risk, spatial patterns, and disease incidenceseverity relationships, 1360

maize chlorotic mottle virus in, in Ethiopia, $1870 \mathrm{~N}$

Mucor irregularis on, in China, 159N

Setosphaeria turcica on, identification and genetic diversity of formae species, 482

Sphacelotheca reiliana on, real-time PCR assay for detection in seedlings and evaluation of treatment efficiency, 1847

Stenocarpella macrospora and Stenocarpella maydis on, molecular assays for detection of, 761

Ustilago maydis on, aflatoxin and fumonisin production and, 1236

Zeng, C. Y., $281 \mathrm{~N}$

Zeng, F., 544

Zeng, H., 731N

Zeng, Q., $1270 \mathrm{~N}$

Zeng, Q. D., 754

Zeng, Y., 291N, 982

Zhai, L., 1704

Zhai, R., 442

Zhan, G. M., 754

Zhan, R.-L., 1653N

Zhang, A.-F., 342

Zhang, C. Q., 1276N, 1284N

Zhang, D., 699, 898N

Zhang, D. Y., 1190N

Zhang, D.-S., 1042N

Zhang, F., 731N

Zhang, G., 544, 1275N, 1333

Zhang, G. Z., $158 \mathrm{~N}$

Zhang, H., 219, 288N, 776

Zhang, H. J., 283N

Zhang, H. L., 155N

Zhang, J., 159N, 283N, 691, 1189N, 1275N, 1426

Zhang, J. Q., 891N

Zhang, K., 442

Zhang, L. F., $1861 \mathrm{~N}$

Zhang, L.-B., 1653N

Zhang, M., 725N, 1176N

Zhang, M. Q., 325

Zhang, S., 422N, 776, 898N, 1184N

Zhang, S. B., 1190N

Zhang, S. H., 1038N

Zhang, S. S., 420N

Zhang, S. Y., 1287N

Zhang, W., 1657N

Zhang, X., 219, 1185N, 1187N, 1569

Zhang, X.-X., 1610

Zhang, Y., 891N

Zhang, Y. P., 1179N

Zhang, Y. Y., 1275N, 1646N

Zhang, Z., 1241

Zhang, Z. J., 291N

Zhang, Z. X., 422N

Zhang, Z.-C., 1042N

Zhang, Z.-F., 249

Zhang, Z.X., $1191 \mathrm{~N}$

Zhao, C., 1757

Zhao, J., 291N, 1113, 1275N, 1285N, 1646N

Zhao, L.-X., 1650N

Zhao, M. L., $1862 \mathrm{~N}$

Zhao, S., 1113

Zhao, W. Q., 1035N

Zhao, Y., 1087, 1175N

Zhao, Y. T., 888N

Zhao, Y.-Z., $1285 \mathrm{~N}$

Zhao, Z., 898N

Zhao, Z. B., $1190 \mathrm{~N}$

Zhao, Z. J., $890 \mathrm{~N}$

Zhao, Z. Y., $1038 \mathrm{~N}$

Zhen, F., 1744

Zheng, H. L., $1275 \mathrm{~N}$

Zheng, L., 159N, 1036N

Zheng, X., 725N, 1651N

Zheng, X. F., 1449N 
Zheng, X. W., 1449N

Zheng, Y.-K., $1650 \mathrm{~N}$

Zhi, H. J., 442

Zhong, L., 1270N

Zhong, Y. K., 442

Zhou, B. G., $1870 \mathrm{~N}$

Zhou, C. Y., 320

Zhou, F.-X., 288N

Zhou, G., 1483

Zhou, H., $1185 \mathrm{~N}, 1187 \mathrm{~N}$

Zhou, H. Y., 291N, 1275N, 1646N

Zhou, J., $1853 \mathrm{~N}$

Zhou, J. N., 416N

Zhou, L. W., 39

Zhou, M., 290N, 969, 1241, 1653N

Zhou, M. Q., 1449N

Zhou, M.-G., 342

Zhou, R., $1277 \mathrm{~N}, 1285 \mathrm{~N}$

Zhou, X., 420N

Zhou, X.-G., 883
Zhou, X.-Y., 1268N

Zhou, Y., 289N, 395, 699, 725N, 731N, 1651N, $1657 \mathrm{~N}$

Zhou, Y. P., 891N

Zhu, F.-X., 267, 1342

Zhu, H., 554N, 1038N, 1040N

Zhu, T. H., 159N

Zhu, X. F., 893N

Zhu, X. P., 888N, 1288N

Zhu, Y. Y., 1273N

Zhu, Y. Z., 289N

Zhu, Z.-Q., 1342

Zia-Ur-Rehman, M., 1287N

Ziegler, D., 551N

Zilberstaine, M., 1048

Zingiber officinale (ginger), Fusarium verticillioides on, in Brazil, $1177 \mathrm{~N}$

Zitnick-Anderson, K. K., 31

Živković, S., 1035N
Ziziphus jujuba (jujube), Alternaria alternata on, $1642 \mathrm{~N}$

Zocli, B., $1640 \mathrm{~N}$

Zoffoli, J. P., 888N

Zoller, B. G., 1147

Zombré, C., $1854 \mathrm{~N}$

Zou, D. X., 289N

Zou, J., 1118

Zoysia japonica (zoysiagrass), Trichodorus obtusus on, in North Carolina, 291N

Zucchini shoestring virus (ZSSV), in zucchini, In South Africa, $1289 \mathrm{~N}$

Zucchini yellow mosaic virus (ZYMV) in chrysanthemum, in China, 1289N

in Cucurbita pepo in Libya, $558 \mathrm{~N}$

transgenic resistance and vertical transmission of, 1616

in ridge gourd, in Pakistan, 1870N

in snake gourd, in India, 558N 